\section{onil}

OAK RIDGE

NATIONAL.

LABORATORY
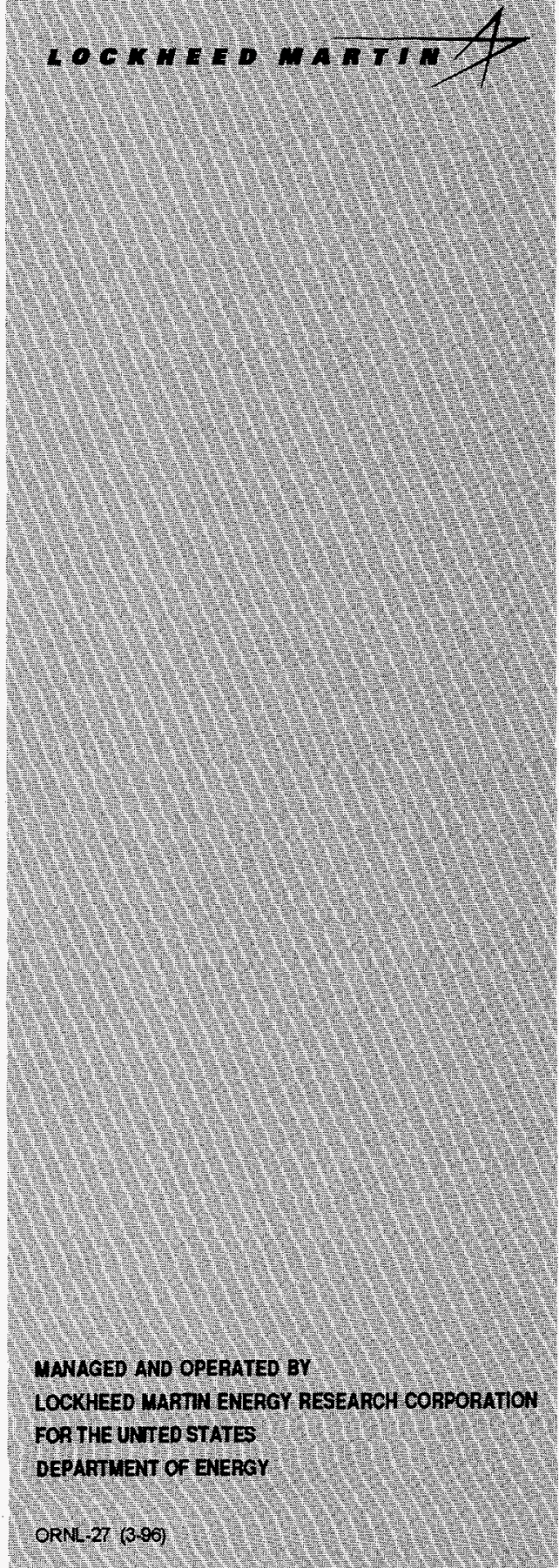

ORNL/CON-437

\section{Review of Water, Lighting, and Cooling Energy Efficiency Measures for Low- Income Homes Located in Warm Climates}

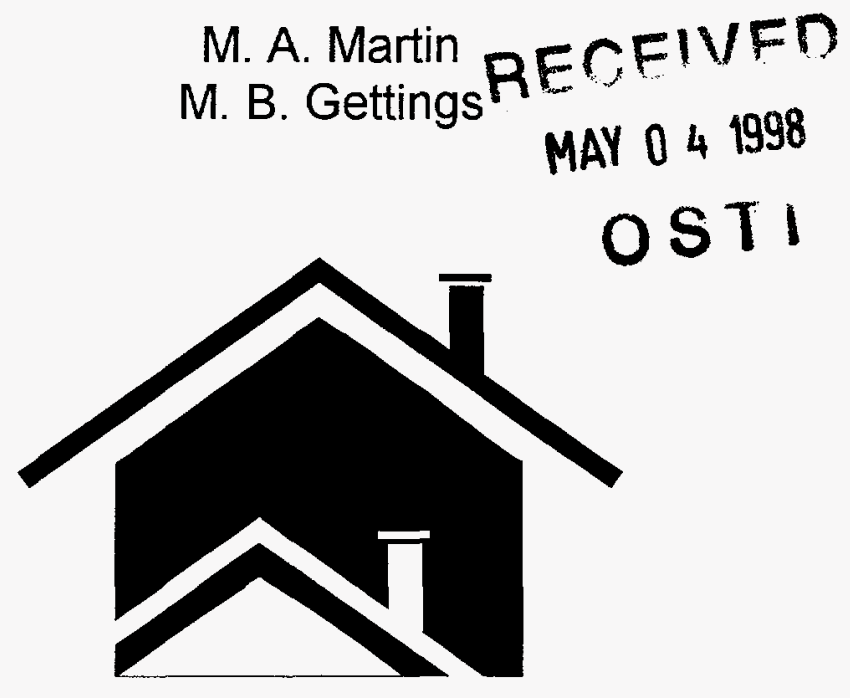

February 1998

DISTRIBUTION OF THIS DOCUMENT IS UNMIMITED ph MASTER 
This report has been reproduced directly from the best available copy.

Available to DOE and DOE contractors from the Office of Scientific and Technical Information, P.O. Box 62, Oak Ridge, TN 37831; prices available from (423) 576-8401, FTS 626-8401.

Available to the public from the National Technical Information Service, U.S. Department of Commerce, 5285 Port Royal Rd., Springfield, VA 22161.

This report was prepared as an account of work sponsored by an agency of the United States Government. Neither the United States Government nor any agency thereof, nor any of their employees, makes any warranty, express or implied, or assumes any legal liability or responsibility for the accuracy, completeness, or usefulness of any information, apparatus, product, or process disclosed, or represents that its use would not infringe privately owned rights. Reference herein to any specific commercial product, process, or service by trade name, trademark, manufacturer, or otherwise, does not necessarily constitute or imply its endorsement, recommendation, or favoring by the United States Government or any agency thereof. The views and opinions of authors expressed herein do not necessarily state or reflect those of the United States Government or any agency thereot. 


\section{DISCLAIMER}

Portions of this document may be illegible electronic image products. Images are produced from the best available original document. 


\title{
Review of Water, Lighting, and Cooling Energy Efficiency Measures for Low-Income Homes Located in Warm Climates
}

\author{
M. A. Martin \\ M. B. Gettings
}

February 1998

Prepared for the Office of Building Technology, State and Community Programs Weatherization Assistance Program U.S. Department of Energy

\author{
Prepared by the \\ OAK RIDGE NATIONAL LABORATORY \\ Oak Ridge, Tennessee 37831 \\ Managed by \\ LOCKHEED MARTIN ENERGY RESEARCH CORPORATION \\ for the \\ U.S. DEPARTMENT OF ENERGY \\ under contract DE-AC05-96OR22464
}





\section{CONTENTS}

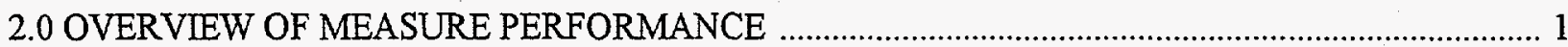

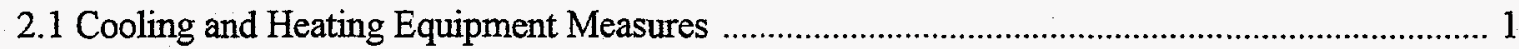

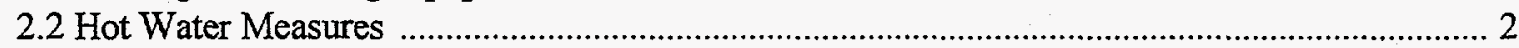

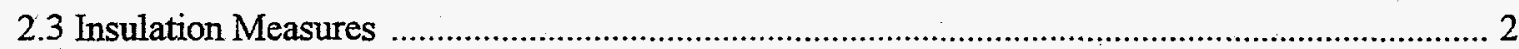

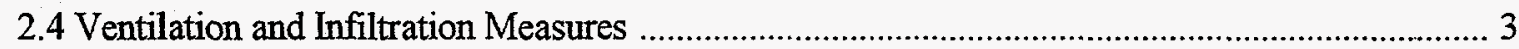

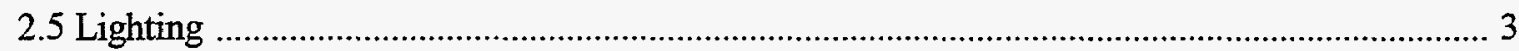

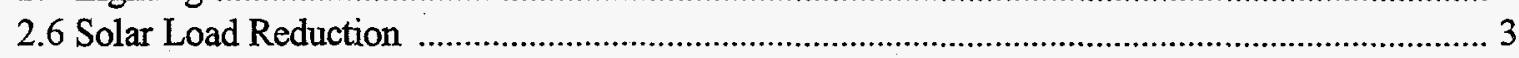

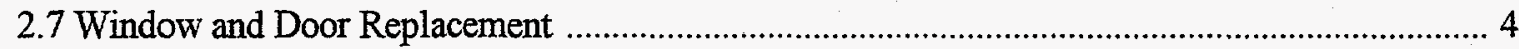

2.8 Appliances

3.0 TABULAR SUMMARY OF MEASURE PERFORMANCE ….................................................. 5

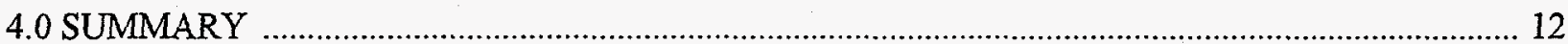

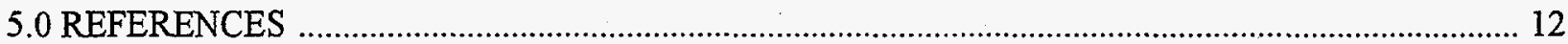

APPENDIX A: DETAILED DESCRIPTION OF RETROFIT TECHNOLOGIES ................................... A.1

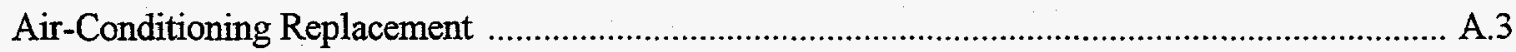

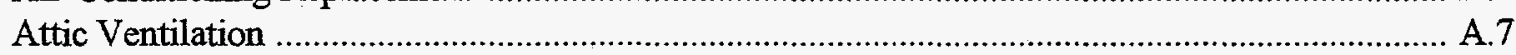

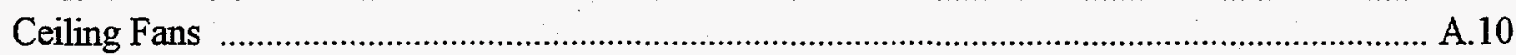

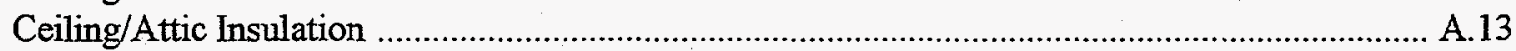

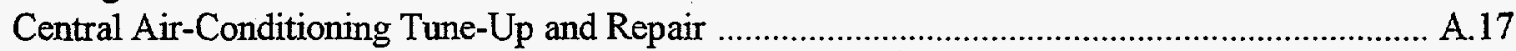

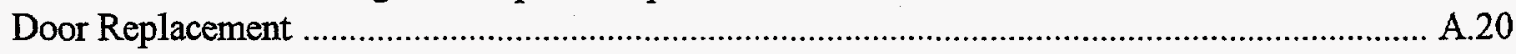

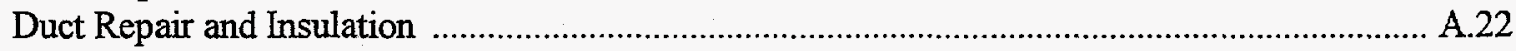

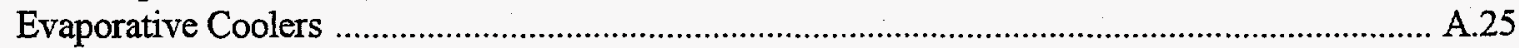

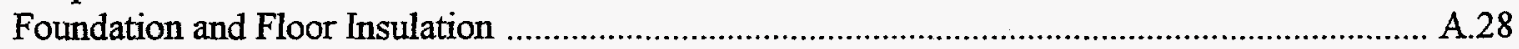

Heat Pump Water Heaters and De-Superheaters ................................................................... A.31

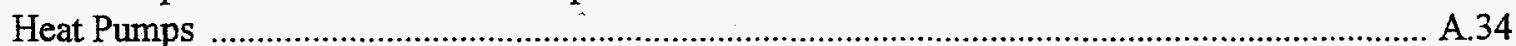

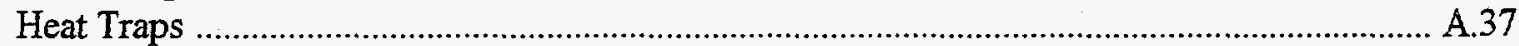

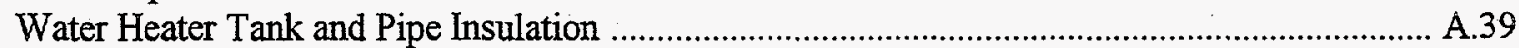

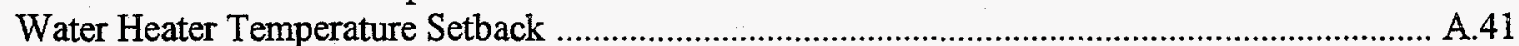

Water Heater Timers and Tankless Water Heaters ................................................................. A.43

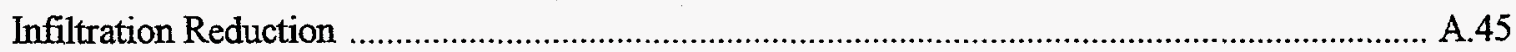

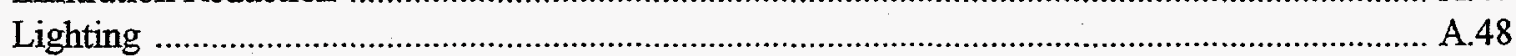

Low-Flow Showerheads and Faucet Aerators …................................................................. A.50

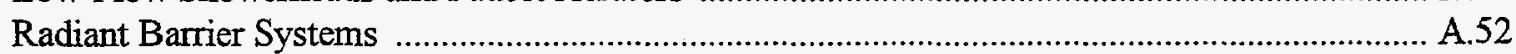

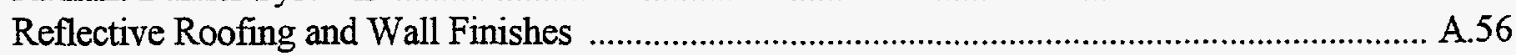

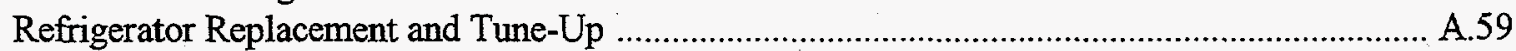

Replacement Washers, Dryers, and Dryer Vents ................................................................ A.62

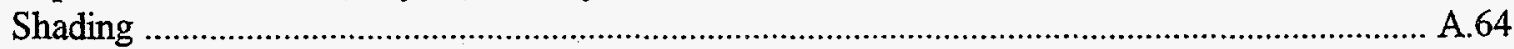


Skirting

Solar Water Heating

Storm Windows

A.76

Wall Insulation

A.79

Whole-House Fans

A.84

Window Replacement

A.87

Window Screens and Natural Ventilation

A.92 


\section{ACKNOWLEDGMENTS}

This research was funded by the U.S. Department of Energy's Weatherization Assistance Program. The authors would like to thank Jeanne VanVlandren and Jean Diggs, of DOE, for their continued support of such work. Additionally, the authors would like to acknowledge D. Parker, D. Shirey, S. Chandra, D. Beal, T. Stedman, J. Cummings, P. Fairey, L. Schrum, and J. Harrison, from the Florida Solar Research Center, and J. Sand, E. Vineyard, and V. Baxter, from the Oak Ridge National Laboratory, for their technical input during the preliminary stages of this study. 


\title{
Review of Water, Lighting, and Cooling Energy Efficiency Measures for Low-Income Homes Located in Warm Climates
}

\author{
M. A. Martin \\ M. B. Gettings
}

In support of the U.S. Department of Energy's Weatherization Assistance Program, Oak Ridge National Laboratory has performed a literature review of weatherization measures applicable for homes located in warm climate regions. Sources for this information included: documented engineering estimates, vendor information, reported performance from research and field tests, and direct discussions with researchers, vendors, and field reporters. Estimated savings are extrapolated from reported energy savings and applied to the end-use energy consumption for low-income homes reported by the Energy Information Administration. Additionally, installation costs, savings-to-investment ratios, and parameters indicating performance sensitivity to issues such as occupancy, construction, client education, and maintenance requirements are presented.

The report is comprised of two sections: an overview of measure performance, and an appendix. The overview of measures is in a tabular format, which allows for quick reference. More detailed discussions and references for each measure are presented in the Appendix and it is highly recommended that these be reviewed prior to measure selection. 


\subsection{INTRODUCTION}

Performance reviews of a wide range of efficiency measures were completed to evaluate their potential application in low-income homes located in warm climates. These reviews were achieved using documented engineering estimates, vendor information, reported performance from research and field tests, and direct discussions with researchers, vendors and field practitioners. The results reflect a compilation of available information and are meant only to aid in the selection, and not to be used as a final verdict, of appropriate measures for cost-effective energy savings.

This report is comprised of two sections: the overview of measure performance and the appendix. The overview briefly discusses each of the measure categories, and then summarizes all measures in a tabular format. The tables list estimated first year savings, installation costs, savings-to-investment ratios (SIR's) ${ }^{*}$ and several sensitivity parameters. The appendix contains detailed information and source references for each measure reviewed. Due to the variation in available information and implementation circumstances, it is highly recommended that the details in the appendix be reviewed prior to measure selection.

\subsection{OVERVIEW OF MEASURE PERFORMANCE}

\subsection{Cooling and Heating Equipment Measures}

This category of efficiency measures includes air-conditioner and heat pump replacement and tune-up, evaporative cooling, and duct sealing and insulation. According to 1990 residential energy consumption data (EIA 1993), cooling energy consumption in low-income homes in warm climates accounts for between $2 \%$ and $15 \%$ of total annual energy consumption. Conversely, heating consumption accounts for nearly $25 \%$ to $43 \%$ of total consumption. On average, in the warm climate regions, $22 \%$ of the homes have central-type air-conditioning systems, $44 \%$ have window air-conditioners, and $34 \%$ do not have any form of mechanical cooling available.

Air-conditioning replacement and tune-up measures present limited potential for energy savings in lowincome homes. Replacement of old inefficient air-conditioners will only result in significant savings when the pre-retrofit use of mechanical cooling is high. Additionally, the type of system installed, window or central, may limit the cost-effectiveness altogether. Homes with window units may be better candidates as the average replacement costs of $\$ 600$ are less than half that for central systems, at $\$ 1,200$. Replacement of heat pumps is expensive and should be done only when existing equipment has reached the end of it's useful lifetime. While many feel that regular tune-ups provide great potential for energy savings and increased lifetime, questions remain about cost-effectiveness and longevity of savings.

Evaporative coolers may be an effective means of reducing conventional air-conditioning consumption in dry, warm climate regions. Energy cost savings are slightly offset by annual maintenance efforts which include the replacement of evaporator pads. Customer education is required in order to ensure annual pad replacement and proper use of the unit to reduce dependence on conventional cooling. A common practice used on existing evaporative systems is the retrofit of fan motors with efficient, 2-speed motors. In dry climates, customer response will be positive as evaporative coolers will significantly reduce their cooling costs while providing a more comfortable environment over conventional cooling.

${ }^{*}$ The SIR is the ratio of the present value of the lifetime monetary savings of the measure, over the initial costs (installation and equipment costs). The discount rate used in all the calculations was $4.1 \%$. 
Recent research has concluded that leaks and conduction losses in air-distribution systems are a major problem for single-family homes in the U.S. Depending on ductwork location, cooling energy consumption may be reduced by $5-30 \%$ as a direct result of detailed sealing efforts. Effective sealing of ductwork should employ diagnostic tools such as a duct blaster or a blower door, along with auditors who have been trained to use them properly. Duct insulation provides significantly lower cooling energy savings and may not be justified based on cooling savings alone.

\subsection{Hot Water Measures}

Hot water heating comprises $17 \%$ to $39 \%$ of the energy consumed by low-income homes in warm climates. Retrofit measures such as tank wrapping, heat traps, timed and reduced temperature setback, and lowflow showerheads are inexpensive and well-established techniques for reducing water-heating energy consumption. While other measures, including solar water heating, tankless water heaters, and heat pump water heaters, have proven savings potential, issues such as first cost, maintenance requirements, and customer inconvenience often inhibit implementation. Regardless, priority should be placed on installation of the lessexpensive measures first, as significant savings can be achieved from these measures.

Insulation, heat traps, and temperature setback all save energy by reducing large stand-by losses. In addition to insulating the first 3 to 5 feet of inlet and outlet piping, uninsulated tanks should be retrofitted with R-7 to R-11 insulation. Heat traps will provide additional energy savings by preventing water flow brought on by natural convection. Tank temperatures greater than $140^{\circ} \mathrm{F}$ may be reduced by $10^{\circ} \mathrm{F}$ or $20^{\circ} \mathrm{F}$, and timers may be installed to reduce tank setpoints during hours of minimal use. Low-flow showerheads may cut water consumption in half, but may result in increased demand for hotter water. The success of these last three measures depends highly on customer acceptance of lower water temperatures.

More expensive, energy-wise systems utilize solar, heat pump, tankless, and de-superheater water heaters. Solar water heaters offer high savings and more cost-effective models that may be used as add-ons are emerging in the market. Heat pump water heaters reduce the energy consumption for water heating while also reducing cooling loads, as heat is removed from the building to heat the water. An adverse effect of this can be higher space-heating loads and heating energy consumption. Waste heat from air-conditioners and heat pumps is used by de-superheating water heaters; however savings are highly dependent on the duty cycle of the supply unit. Both heat pump and de-superheating water heaters are usually most effective in warmer climates. Stand-by losses can be completely eliminated through the use of tankless, or demand water heaters, however delivery rates are low and electric units are likely to be discouraged by electric utility's interested in demand reduction.

\subsection{Insulation Measures}

Insulation is an effective means of saving energy in the home, although heating benefits far outweigh cooling benefits. DOE guidelines listed in the 1988 Insulation Fact Sheet (DOE 1988) should be followed when determining location and appropriate levels of insulation. Also, advanced audits, such as NEAT, may be used to determine optimal levels. Attic insulation is common practice throughout the warm climate region and cooling savings will be highest in buildings with no pre-existing insulation. In homes without air-conditioning, additional comfort may be provided as increased attic insulation aids in the reduction of living space temperature. Studies have found that infiltration may reduce the effective $\mathrm{R}$-value of insulation by as much as $50 \%$. Thus, infiltration reduction measures should be implemented in preparation for the installation of insulation. Insulation retrofits are not recommended for slab foundations due to their high expense. Conventional practice advises that 
well-insulated attics be adequately ventilated and insulated walls have the ability dry. Though insulation will always decrease heating energy use, in mild climates in homes with high internal loads, high levels of insulation may increase the cooling energy use.

\subsection{Ventilation and Infiltration Measures}

Ventilation measures work to remove heat from the home while infiltration reduction measures will prevent heat from entering. Passive attic ventilation retrofits are usually implemented in homes receiving attic insulation. Forced attic ventilation may provide a small additional cooling benefit; however, this is usually offset by the additional energy consumed to power the fan. Solar powered fans are available on the market, but are not yet cost effective. Whole house fans may provide relief to clients without air-conditioning, by substantially increasing the flow of fresh air into the home. In homes with air-conditioners, some energy may be saved by displacing the cooling supply with a whole-house fan. Ceiling and portable fans will also provide some relief by enhancing natural convection cooling through slightly increased air-movement. When used in conjunction with air-conditioners, the use of ceiling and portable fans may result in higher set points and a corresponding drop in air-conditioning consumption.

Reductions in infiltration up to $30 \%$ can be achieved through aggressive detection and sealing techniques, and through proper education of auditors. Early approaches, including weatherstripping of windows and doors, are not as effective as efforts that concentrate on leakage sites that are located further from the 'neutral pressure zone', such as attics and foundations. Infiltration reduction is highly recommended prior to installation of attic insulation, in order to maintain effective R-values. Skirting of mobile homes and homes on stilts will reduce infiltration through the floor, but may not be as effective as floor insulation. Although little evidence exists documenting cooling energy savings, infiltration retrofits should be performed to take advantage of potentially large heating savings.

\subsection{Lighting}

The replacement of incandescent lamps with energy efficient fluorescent lamps is an effective way to save energy when done on high-usage lamps. Efforts to replace incandescents are moderate, and more auditors should take advantage of them due to their low-cost and easy installation. The replacement of high-use lamps will result in greater savings. Auditors will be able to replace a maximum number of lamps when well-prepared with a stock of different wattages, configurations and adapters. Customer reception of this measure will also play a large role in it's success, as dissatisfaction usually results in removal.

\subsection{Solar Load Reduction}

Solar loads contribute significantly to the cooling loads for homes located in the warm climate. Measures including solar screens and films, and interior and exterior shading devices are all effective, to some degree, at reducing solar loads. Other means, such as radiant barriers, shading with trees, and reflective exterior roof coatings have established savings.

Selection of solar load reduction measures will be highly dependent on occupant acceptance, cost and configuration of the home itself. Cooling energy savings will only be achievable if mechanical equipment is used for cooling purposes. In situations where air-conditioners do not exist, the reduction of intense summer solar loads will provide relief to occupants through lower indoor temperatures. Often, insect screens requiring replacement present a good opportunity for retrofits with solar screens. While several shading measures may 
effectively reduce the summer time solar loads, they may also reduce the free solar heating provided during heating months. To avoid this, client education is required in order to ensure that solar screens installed prior to the cooling season, are removed for the heating season. Additionally, savings may be reduced as occupants use interior lighting to offset the loss of natural daylighting. Thus, client education and an appropriate selection strategy are beneficial to the success of any solar reduction measure.

Radiant barriers and reflective exterior roofing may be effective means of reducing solar loads on a home. White reflective paints and other coatings may provide savings, particularly in manufactured homes. However, overall impacts will depend highly on initial insulation levels, air-duct location, air-conditioner sizing and eventual degradation of the reflective properties over time. Specifically, savings associated with reflective roofing tend to be higher when installed in uninsulated attics; and savings may not be very high if attic insulation were installed. In mobile homes and homes with low-slope roofs, reflective roofing can be applied when there is little room for ceiling insulation. Several studies have indicated a $5 \%$ to $20 \%$ reduction in cooling energy consumption associated with radiant barriers, however some have reported little or no improvement. Existing conditions such as insulation level and type of air-conditioning system should be considered and implementation of radiant barriers should occur only in regions with extreme cooling needs.

\subsection{Window and Door Replacement}

Window, storm window, and door replacements are commonly implemented measures for low-income retrofit applications. The foundation for energy savings is mostly comprised of infiltration reduction and heating energy savings. As many low-income homes are in desperate need of repair, these replacements may take priority over other measures. Storm windows will reduce conduction losses and, if tightly fit, will reduce infiltration through windows which may not be sealed in any other manner. Additionally, storm windows may be a less costly solution to window replacement. Window retrofit efforts in warm climates should consider replacements with 'low-e' coatings. These windows have higher R-values and are able to block solar heat gain while allowing good transmission of light.

\subsection{Appliances}

Preliminary studies have determined that significant energy savings may be achieved with the new generation of energy efficient refrigerators, while only small impacts are presently obtainable with new advances in washer and dryer technologies. The new technologies in washing and drying clothes, using horizontal-axis washers and microwave dryers, have not yet penetrated the U.S. market, and in some cases may be stalled in the development stage.

Based on 1990 residential EIA data (1993), refrigerators consume approximately $8 \%$ of the energy consumed by the low-income homes in the warm climate region. This equates to an average annual consumption of $1,400 \mathrm{kWh}$, which indicates that most of the units in place are old and extremely inefficient. Replacement with relatively inexpensive energy efficient units has the potential to save up to $50 \%$ of the original annual consumption as these units would only use approximately $700 \mathrm{kWh} / \mathrm{yr}$. Tune-up efforts, such as coil cleaning and sealing of leaky doors, do not seem to have a significant impact on consumption. The cost of replacement seals are such that total refrigerator replacement may be more sensible. 


\subsection{TABULAR SUMMARY OF MEASURE PERFORMANCE}

The results of the literature reviews are summarized in Tables 3.1. For each measure, approximate first year energy and cost savings, installation cost, and savings-to-investment ratio (SIR) are listed. Additionally, sensitivity parameters are provided and are meant to guide users in evaluating how each measure would work for their individual warm climate regions, clients, and housing types. The effect that these parameters have on the success of each measure is rated on a scale defined as low, medium or high. The definitions for each are listed in Figure 3.1 .

Figure 3.1. Definitions of sensitivity parameters for efficiency measures

Maintenance requirements define the dependence of the measure's success on annual maintenance activities. A rating of 'Low' indicates that little or no maintenance is required to achieve predicted savings, while 'High' suggests that extensive maintenance efforts are necessary.

Customer interaction reflects the sensitivity of the measure's performance to the customer's response. In some cases, the success of the measure will depend on whether or not it is actually utilized by the customer (index = 'High'), while for other measures, customer interaction is minimal and has little effect on measure performance (index $=$ 'Low').

Customer education defines the dependence of the measure's success on customer knowledge and understanding of the product. Some effort may be involved on the customer's part, in order to ensure maximum energy savings, and this effort will require some amount of education (index = 'Med' or 'High')

Climate indicates the sensitivity of the measure's performance to the local climate. Some measures will produce similar results despite climatic conditions (index $=$ 'Low'), whereas others, such as airconditioning, will be highly dependent on the climate and the resulting demand for air-conditioning (index $=$ 'High')

Building characteristics reflect the sensitivity of the measure to building conditions such as pre-existing insulation levels, construction, and efficiency of hot water and air distribution systems. In order to ensure maximum effectiveness of the measure, these issues must be considered when this index is rated as 'Med' or 'High'.

Occupancy indicates the sensitivity of the measure to occupancy levels and fluctuations. Measures that operate relatively independent of occupant influence will be rated as 'Low', while those highly effected by tenant behavior will be rated as 'High'.

Confidence level reflects the degree of certainty of the data used to determine SIR's. This is based on the quality of the information available from research studies and reports of practical applications. 
Table 3.1a. Performance summary of warm climate efficiency measures for low-income homes

\begin{tabular}{|c|c|c|c|c|c|c|c|c|c|c|}
\hline Measure & $\begin{array}{c}\text { 1st Year Savings } \\
(\mathrm{kWh}, \mathrm{MBtu}, \%, \$)\end{array}$ & $\begin{array}{c}\text { Installation } \\
\text { Cost } \\
(\$) \\
\end{array}$ & $\begin{array}{c}\text { SIR } \\
\left({ }^{*}=\text { cooling only }\right)\end{array}$ & $\begin{array}{r}\text { Maintenance } \\
\text { Requirements } \\
(\mathrm{Le} / \mathrm{Med} / \mathrm{Hi})\end{array}$ & $\begin{array}{c}\text { Customer } \\
\text { Interaction } \\
\text { (Lo/Med/Hi) }\end{array}$ & $\begin{array}{c}\text { Customer } \\
\text { Education } \\
\text { (Lo/Med/Hi) }\end{array}$ & $\begin{array}{c}\text { Climate } \\
\text { (Lo/Med/Hi) }\end{array}$ & $\begin{array}{l}\text { Bldg. Chars } \\
\text { (Lo/Med/Hi) }\end{array}$ & $\begin{array}{c}\text { Occupancy } \\
\text { (Lo/Med/Hi) }\end{array}$ & $\begin{array}{c}\text { Confidence } \\
\text { Level } \\
\text { (Lo/Med/Hi) }\end{array}$ \\
\hline \multicolumn{11}{|c|}{ Cooling and Heating Equipment Measures } \\
\hline $\begin{array}{l}\text { Air-Conditioner } \\
\text { Tune-Up }\end{array}$ & $\begin{array}{c}90-790 \mathrm{kWh} \\
\$ 7-\$ 64\end{array}$ & $\$ 80$ & $0.20 *-1.4 *$ & Med & High & Med & High & High & Med & Med \\
\hline $\begin{array}{l}\text { Window Air- } \\
\text { Conditioner } \\
\text { Replacement }\end{array}$ & $\begin{array}{c}100-890 \mathrm{kWh} \\
\$ 8-\$ 71\end{array}$ & $\$ 600$ & $0.15^{*}-1.3 *$ & Med & High & Med & High & High & Med & Med \\
\hline $\begin{array}{l}\text { Central Air- } \\
\text { Conditioner } \\
\text { Replacement }\end{array}$ & $\begin{array}{c}100-890 \mathrm{kWh} \\
\$ 8-\$ 71\end{array}$ & $\$ 1,500$ & $0.06^{*}-0.77^{*}$ & Med & High & Med & High & High & Med & Med \\
\hline $\begin{array}{l}\text { Heat Pump } \\
\text { Installation }\end{array}$ & $\begin{array}{c}2400-5240 \mathrm{kWh} \\
\$ 193-\$ 419 \\
\text { see Appendix A }\end{array}$ & $\$ 3,500$ & $0.61-1.32$ & Med & High & Med & High & High & Med & Low \\
\hline $\begin{array}{c}\text { Evaporative } \\
\text { Cooler Installation }\end{array}$ & $\begin{array}{c}960 \mathrm{kWh} \\
\$ 77\end{array}$ & $\$ 1,000$ & $0.72 *$ & High & Med & High & High & High & Low & Med \\
\hline Duct Sealing & $\begin{array}{c}60-500 \mathrm{kWh} \\
\$ 4-\$ 40\end{array}$ & $\$ 200$ & $0.16^{*}-1.63^{*}$ & Low & Med & Low & Med & High & Low & High \\
\hline Duct Insulation & $\begin{array}{c}6-55 \mathrm{kWh} \\
\$ 1-\$ 9\end{array}$ & $\$ 450$ & Low* & Low & Med & Low & Med & High & Low & Low \\
\hline \multicolumn{11}{|c|}{ Hot Water Measures } \\
\hline $\begin{array}{c}\text { Heat Traps on } \\
\text { Electric Hot } \\
\text { Water Tank }\end{array}$ & $\begin{array}{c}210 \mathrm{kWh} \\
\$ 17\end{array}$ & $\$ 30$ & 5.7 & Low & Low & Low & Low & Low & Low & High \\
\hline $\begin{array}{c}\text { Heat Traps on } \\
\text { Gas-Fired Hot } \\
\text { Water Tank }\end{array}$ & $\begin{array}{c}0.72 \mathrm{MBtu} \\
\$ 5\end{array}$ & $\$ 30$ & 0.57 & Low & Low & Low & Low & Low & Low & High \\
\hline $\begin{array}{c}\text { Electric Water } \\
\text { Heater Tank } \\
\text { Insulation } \\
\end{array}$ & $\begin{array}{c}125-475 \mathrm{kWh} \\
\$ 10-\$ 38\end{array}$ & $\$ 25$ & $4-15$ & Low & Low & Low & Low & Low & Low & High \\
\hline
\end{tabular}

1) See Figure 3.1 for definitions of sensitivity parameters

2) See Appendix A for assumptions regarding installation costs, energy costs, equipment lifetime, and sensitivity issues 
Table 3.1b. Performance summary of warm climate efficiency measures for low-income homes (Cont'd)

\begin{tabular}{|c|c|c|c|c|c|c|c|c|c|c|}
\hline Measure & $\begin{array}{c}\text { 1st Year Savings } \\
(\mathrm{kWh}, \mathrm{MBtu}, \%, \$)\end{array}$ & $\begin{array}{l}\text { Installation } \\
\text { Cost } \\
\text { (\$) }\end{array}$ & $\begin{array}{c}\text { SIR } \\
\left({ }^{*}=\text { cooling only }\right)\end{array}$ & $\begin{array}{l}\text { Maintenance } \\
\text { Requirements } \\
\text { (Lo/ Med/Hi) }\end{array}$ & $\begin{array}{c}\text { Customer } \\
\text { Interaction } \\
\text { (Lo/Med/Hi) }\end{array}$ & $\begin{array}{c}\text { Customer } \\
\text { Education } \\
\text { (Lo/Med/Hi) }\end{array}$ & $\begin{array}{c}\text { Climate } \\
(\mathrm{Lo} / \mathrm{Med} / \mathrm{Hi})\end{array}$ & $\begin{array}{l}\text { Bldg. Clars } \\
\text { (Lo/Med/Hi) }\end{array}$ & $\begin{array}{l}\text { Occupancy } \\
\text { (Lo/Med/Hi) }\end{array}$ & $\begin{array}{c}\text { Confidence } \\
\text { Level } \\
(\text { Lo/Med/Hi) }\end{array}$ \\
\hline $\begin{array}{l}\text { Gas-Fired Water } \\
\text { Heater Tank } \\
\text { Insulation }\end{array}$ & $\begin{array}{c}0.43-1.62 \mathrm{MBtu} \\
\$ 3-\$ 10\end{array}$ & $\$ 25$ & $1.4-4.6$ & Low & Low & Low & Low & Low & Low & High \\
\hline $\begin{array}{l}\text { Electric Water } \\
\text { Heater Temp. } \\
\text { Setback }\end{array}$ & $\begin{array}{c}125-210 \mathrm{kWh} \\
\$ 10-\$ 17\end{array}$ & $\$ 0$ & High & Low & High & High & Low & Low & Low & Med \\
\hline $\begin{array}{c}\text { Gas-Fired Water } \\
\text { Heater Temp. } \\
\text { Setback }\end{array}$ & $\begin{array}{c}0.43-0.72 \mathrm{MBtu} \\
\$ 3-\$ 4\end{array}$ & $\$ 0$ & High & Low & High & High & Low & Low & Low & Med \\
\hline $\begin{array}{c}\text { Water Heater } \\
\text { Timer }\end{array}$ & $\begin{array}{l}125 \mathrm{kWh} \\
\$ 10\end{array}$ & $\$ 30$ & 3.4 & High & High & High & Low & Low & Med & Low \\
\hline $\begin{array}{l}\text { Electric Tankless } \\
\text { Water Heater }\end{array}$ & $\begin{array}{c}315-790 \mathrm{kWh} \\
\$ 25-\$ 63\end{array}$ & $\$ 795$ & $0.32-0.8$ & Low & High & High & Low & Med & Med & Med \\
\hline $\begin{array}{l}\text { Gas Tankless } \\
\text { Water Heater }\end{array}$ & $\begin{array}{c}1.1-2.7 \mathrm{MBtu} \\
\$ 7-\$ 17\end{array}$ & $\$ 1,174$ & $0.07-0.17$ & Low & High & High & Low & Med & Med & Med \\
\hline $\begin{array}{c}\text { Small Solar Water } \\
\text { Heater }\end{array}$ & $\begin{array}{l}2,000 \mathrm{kWh} \\
\quad \$ 165\end{array}$ & $\$ 1,050$ & 2.19 & Med & Med & High & Med & Med & Med & Med \\
\hline $\begin{array}{c}\text { Large Solar Water } \\
\text { Heater }\end{array}$ & $\begin{array}{c}1,770-2,950 \mathrm{kWh} \\
\$ 142-\$ 236\end{array}$ & $\$ 2,500$ & $0.79-1.31$ & Med & Med & High & Med & Med & Med & Med \\
\hline $\begin{array}{c}\text { Low-Flow } \\
\text { Showerhead - } \\
\text { Electric Heater }\end{array}$ & $\begin{array}{c}340 \mathrm{kWh} \\
\$ 27\end{array}$ & $\$ 30$ & 8.8 & Low & High & Med & Low & Low & Med & Low \\
\hline $\begin{array}{c}\text { Low-Flow } \\
\text { Showerhead - } \\
\text { Gas-Fired Heater }\end{array}$ & $\begin{array}{l}1.2 \mathrm{MBtu} \\
\$ 7\end{array}$ & $\$ 30$ & 2.6 & Low & High & Med & Low & Low & Med & Low \\
\hline $\begin{array}{l}\text { Faucet Aerator - } \\
\text { Electric Heater }\end{array}$ & $\begin{array}{l}150 \mathrm{kWh} \\
\$ 12\end{array}$ & $\$ 2$ & High & Low & Med & Med & Low & Low & Med & Low \\
\hline $\begin{array}{l}\text { Faucet Aerator - } \\
\text { Gas-Fired Heater }\end{array}$ & $\begin{array}{c}0.5 \mathrm{MBtu} \\
\$ 3\end{array}$ & $\$ 2$ & High & Low & Med & Med & Low & Low & Med & Low \\
\hline
\end{tabular}

1) See Figure 3.1 for definitions of sensitivity parameters

2) Sec Appendix A for assumptions regarding installation costs, energy costs, equipment lifetime, and sensitivity issues 
Table 3.1c. Performance summary of warm climate efficiency measures for low-income homes (Cont'd)

\begin{tabular}{|c|c|c|c|c|c|c|c|c|c|c|}
\hline Measure & $\begin{array}{l}\text { 1st Year Savings } \\
\text { (kWh, MBtu, \%, } \\
\text { \$) }\end{array}$ & $\begin{array}{l}\text { Installation } \\
\text { Cost } \\
\text { (\$) }\end{array}$ & $\begin{array}{c}\text { SIR } \\
\left({ }^{*}=\text { cooling only }\right)\end{array}$ & $\begin{array}{c}\text { Maintenance } \\
\text { Requirements } \\
\text { (Lo/ Med/Hi) }\end{array}$ & $\begin{array}{c}\text { Customer } \\
\text { Interaction } \\
\text { (Lo/Med/Hi) }\end{array}$ & $\begin{array}{c}\text { Customer } \\
\text { Education } \\
(\text { Lo/Med/Hi) }\end{array}$ & $\begin{array}{c}\text { Climate } \\
\text { (Lo/Med/Hi) }\end{array}$ & $\begin{array}{l}\text { Bldg. Chars } \\
\text { (Lo/Med/Hi) }\end{array}$ & $\begin{array}{c}\text { Occupancy } \\
\text { (Lo/Med/Hi) }\end{array}$ & $\begin{array}{c}\text { Confidence } \\
\text { Level } \\
\text { (Lo/Med/Hi) }\end{array}$ \\
\hline $\begin{array}{c}\text { Heat Pump Water } \\
\text { Heaters } \\
\text { (replacing elec. units) }\end{array}$ & $\begin{array}{c}1,270-2,110 \\
\text { kWh } \\
\$ 101-\$ 170\end{array}$ & $\$ 825$ & $1.4-2.3$ & Med & Low & Med & Med & Med & Med & Low \\
\hline $\begin{array}{l}\text { Heat Pump Water } \\
\text { Heaters } \\
\text { (replacing gas units) }\end{array}$ & $\begin{array}{c}10.8-18 \mathrm{MBtu} \\
\$ 27-\$ 45\end{array}$ & $\$ 825$ & $0.4-0.7$ & Med & Low & Med & Med & Med & Med & Low \\
\hline $\begin{array}{l}\text { De-superheater } \\
\text { Water Heaters }\end{array}$ & see Appendix A & $\$ 500-\$ 600$ & $\mathrm{n} / \mathrm{a}$ & Low & Low & Med & Med & High & Med & Low \\
\hline \multicolumn{11}{|c|}{ Insulation Measures } \\
\hline $\begin{array}{l}\text { Add Attic Insulation } \\
\text { (R-19 to R-30) }\end{array}$ & $\begin{array}{c}40-110 \mathrm{kWh} \\
\$ 3-\$ 9\end{array}$ & $\$ 400$ & $0.12^{*}-0.33^{*}$ & Low & Low & Low & High & Med & Low & Med \\
\hline $\begin{array}{l}\text { Foundation Insulation } \\
\text { (Basement) }\end{array}$ & $\begin{array}{l}190 \mathrm{kWh} \\
\$ 15\end{array}$ & $\$ 640$ & $0.38 *$ & Low & Low & Low & High & High & Low & High \\
\hline $\begin{array}{l}\text { Foundation Insulation } \\
\text { (Crawl Space) }\end{array}$ & $\begin{array}{l}200 \mathrm{kWh} \\
\$ 16\end{array}$ & $\$ 600$ & $0.45^{*}$ & Low & Low & Low & High & High & Low & High \\
\hline $\begin{array}{l}\text { Foundation Insulation } \\
\text { (Slab-on-Grade) }\end{array}$ & $\begin{array}{c}70-240 \mathrm{kWh} \\
\$ 5-\$ 20\end{array}$ & $\$ 5-\$ 20$ & $0.05-0.19$ & Low & Low & Low & High & High & Low & High \\
\hline $\begin{array}{c}\text { Wall Insulation } \\
\text { Wood-Frame Walls } \\
\text { (w/ attic insulation) }\end{array}$ & $\begin{array}{c}35-357 \mathrm{kWh} \\
\$ 3-\$ 29\end{array}$ & $\begin{array}{c}\$ 1,180 \\
\left(\$ 0.80 / \mathrm{ft}^{2}\right)\end{array}$ & $0.04 *-0.40^{*}$ & Low & Low & Low & High & High & Low & Med \\
\hline $\begin{array}{c}\text { Wall Insulation } \\
\text { Masonry Walls } \\
\text { (w/ attic insulation) }\end{array}$ & $\begin{array}{c}35-357 \mathrm{kWh} \\
\$ 3-\$ 29\end{array}$ & $\begin{array}{c}\$ 4,930 \\
\left(\$ 3.34 / \mathrm{ft}^{2}\right)\end{array}$ & $0^{*}-0.09^{*}$ & Low & Low & Low & High & High & Low & Med \\
\hline
\end{tabular}

1) See Figure 3.1 for definitions of sensitivity parameters

2) See Appendix A for assumptions regarding installation costs, energy costs, equipment lifetime, and sensitivity issues 
Table 3.1d. Performance summary of warm climate efficiency measures for low-income homes (Cont'd)

\begin{tabular}{|c|c|c|c|c|c|c|c|c|c|c|}
\hline Measure & $\begin{array}{c}\text { 1st Year Savings } \\
(\mathrm{kWh}, \mathrm{MBtu}, \%, \$)\end{array}$ & $\begin{array}{l}\text { Installation } \\
\text { Cost } \\
(\$)\end{array}$ & $\begin{array}{c}\text { SIR } \\
(*=\text { cooling only })\end{array}$ & $\begin{array}{c}\text { Maintenance } \\
\text { Requirements } \\
\text { (Lo/Med/Hi) }\end{array}$ & $\begin{array}{l}\text { Customer } \\
\text { Interaction } \\
\text { (Lo/Med/Hi }\end{array}$ & $\begin{array}{c}\text { Customer } \\
\text { Education } \\
\text { (Lo/Med/Hi) }\end{array}$ & $\begin{array}{c}\text { Climate } \\
\text { (Lo/Med/Hi) }\end{array}$ & $\begin{array}{l}\text { Bldg. Chars } \\
\text { (Lo/Med/Hi) }\end{array}$ & $\begin{array}{l}\text { Occupancy } \\
\text { (Lo/Med/Hi) }\end{array}$ & $\begin{array}{c}\text { Confidence } \\
\text { Level } \\
\text { (Lo/Med/Hi) }\end{array}$ \\
\hline \multicolumn{11}{|c|}{ Ventilation and Infiltration Measires } \\
\hline $\begin{array}{l}\text { Attic Ventilation } \\
\text { (Passive) }\end{array}$ & $\begin{array}{c}10-85 \mathrm{kWh} \\
\$ 1-\$ 6\end{array}$ & $\$ 50$ & $0.22-1.36$ & Low & Low & Low & High & High & Low & Med \\
\hline $\begin{array}{l}\text { Attic Ventilation } \\
\text { (Forced Solar } \\
\text { Powered) }\end{array}$ & $\begin{array}{c}2-170 \mathrm{kWh} \\
\$ 2-\$ 13\end{array}$ & $\$ 800$ & $0.02-0.13$ & Med & Low & Med & High & High & Low & Med \\
\hline $\begin{array}{l}\text { Infiltration } \\
\text { Reduction }\end{array}$ & not available & $\$ 300-\$ 350$ & not available & Low & Low & Low & High & High & Low & Low \\
\hline $\begin{array}{c}\text { Skirting } \\
\text { (Heat Pump, Gas) }\end{array}$ & $\begin{array}{c}24-483 \mathrm{kWh} \\
\$ 1-\$ 39\end{array}$ & $\$ 300$ & $0.03-0.77$ & Med & Low & Low & Med & Med & Low & Med \\
\hline $\begin{array}{c}\text { Skirting } \\
\text { (Electric Resistance } \\
\text { Heat) }\end{array}$ & $\begin{array}{c}45-917 \mathrm{kWh} \\
\$ 4-\$ 73\end{array}$ & $\$ 300$ & $0.07-1.47$ & Med & Low & Low & Med & Med & Low & Med \\
\hline $\begin{array}{l}\text { Whole-House Fan } \\
\text { Installation }\end{array}$ & $\begin{array}{c}50-328 \mathrm{kWh} \\
\$ 4-\$ 26\end{array}$ & $\$ 200$ & $0.17-1.06$ & Med & High & High & High & Med & Med & Med \\
\hline $\begin{array}{l}\text { Ceiling Fan } \\
\text { Installation }\end{array}$ & $\begin{array}{c}39-334 \mathrm{kWh} \\
\$ 3-\$ 27\end{array}$ & $\$ 100 /$ fan & $0.06-0.55$ & Low & High & Med & Med & Med & Med & Low \\
\hline $\begin{array}{l}\text { Window Screen } \\
\text { Installation }\end{array}$ & not available & $\$ 12-\$ 20$ & not available & Low & High & Med & Med & Med & Low & Low \\
\hline \multicolumn{11}{|c|}{ Uighting Measures } \\
\hline $\begin{array}{c}\text { Lighting } \\
\text { Replacement } \\
\text { (5-6lamns) }\end{array}$ & $\begin{array}{c}220-320 \mathrm{kWh} \\
\$ 18-\$ 26\end{array}$ & $\$ 90-\$ 110$ & $1.2-1.4$ & Low & High & Med & Low & High & Med & High \\
\hline
\end{tabular}

1) See Figure 3.1 for definitions of sensitivity parameters

2) See Appendix A for assumptions regarding installation costs, energy costs, equipment lifetime, and sensitivity issues 
Table 3.1e. Performance summary of warm climate efficiency measures for low-income homes (Cont'd)

\begin{tabular}{|c|c|c|c|c|c|c|c|c|c|c|}
\hline Measure & $\begin{array}{c}\text { 1st Year Savings } \\
\text { (kWh, MBtu, \%, \$) }\end{array}$ & $\begin{array}{c}\text { Installation } \\
\text { Cost } \\
(\$)\end{array}$ & $\begin{array}{c}\text { SIR } \\
\left({ }^{*}=\text { coolling only }\right)\end{array}$ & $\begin{array}{c}\text { Maintenance } \\
\text { Requirements } \\
\text { (Lo/ Med/Hi) }\end{array}$ & $\begin{array}{c}\text { Customer } \\
\text { Interaction } \\
\text { (Lo/Med/Hi }\end{array}$ & $\begin{array}{c}\text { Customer } \\
\text { Education } \\
\text { (Lo/Med/Hi) }\end{array}$ & $\begin{array}{c}\text { Climate } \\
\text { (Lo/Med/Hi) }\end{array}$ & $\begin{array}{l}\text { Bldg. Chars } \\
\text { (Lo/Med/Hi) }\end{array}$ & $\begin{array}{l}\text { Occupancy } \\
\text { (Lo/Med/Hi) }\end{array}$ & $\begin{array}{c}\text { Confidence } \\
\text { Level } \\
\text { (Lo/Med/Hi) }\end{array}$ \\
\hline \multicolumn{11}{|c|}{ Solar Iooad Reduction Measures } \\
\hline $\begin{array}{l}\text { Solar Screens/Films } \\
\text { (used all year) }\end{array}$ & $\$ 0-\$ 10$ per unit & $\$ 37$ per unit & $0-2.0$ & Med & Med & Med & High & High & Low & Med \\
\hline $\begin{array}{l}\text { Solar Screens/Films } \\
\text { (summer use only) }\end{array}$ & $\$ 4-\$ 10$ per unit & $\$ 37$ per unit & $0.6-2.2$ & Med & High & Med & High & High & Low & Med \\
\hline Shade Trees & $27 \%-58 \%$ & not available & not available & Low & Low & Low & High & High & Low & Low \\
\hline $\begin{array}{l}\text { Radiant Barriers } \\
\text { (w/ R-11 attic ins.) }\end{array}$ & not available & $\begin{array}{c}\$ 360 \\
\left(\$ 0.32 / \mathrm{fl}^{2}\right)\end{array}$ & $0.51-0.86$ & Low & Low & Low & High & High & Low & High \\
\hline $\begin{array}{l}\text { Radiant Barriers } \\
\text { (w/ R-19 attic ins.) }\end{array}$ & not available & $\begin{array}{c}\$ 360 \\
\left(\$ 0.32 / \mathfrak{f}^{2}\right)\end{array}$ & $0.26-0.46$ & Low & Low & Low & High & High & Low & High \\
\hline $\begin{array}{l}\text { Radiant Barriers } \\
\text { (w/ R-30 attic ins.) }\end{array}$ & not available & $\begin{array}{c}\$ 360 \\
\left(\$ 0.32 / \mathrm{ft}^{2}\right)\end{array}$ & $0.15-0.31$ & Low & Low & Low & High & High & Low & High \\
\hline $\begin{array}{l}\text { Reflective Roofing } \\
\text { (Uninsulated Attic) }\end{array}$ & $\begin{array}{c}117-1,113 \mathrm{kWh} \\
\$ 9-\$ 89\end{array}$ & $\begin{array}{c}\$ 400 \\
\left(\$ 40 / \mathrm{ft}^{2}\right)\end{array}$ & $0.14^{*}-1.34^{*}$ & High & Med & Med & High & Med & Low & Low \\
\hline $\begin{array}{l}\text { Reflective Roofing } \\
\text { (Insulated Attic) }\end{array}$ & $\begin{array}{c}29-278 \mathrm{kWh} \\
\$ 2-\$ 22\end{array}$ & $\begin{array}{c}\$ 400 \\
\left(\$ 40 / \mathfrak{t}^{2}\right)\end{array}$ & $0.04^{*}-0.33^{*}$ & High & Med & Med & High & Med & Low & Low \\
\hline Reflective Walls & $\begin{array}{c}15-139 \mathrm{kWh} \\
\$ 1-\$ 11\end{array}$ & $\$ 0.25 / \mathrm{ft}^{2}$ & $0.02 *-0.67^{*}$ & Med & Med & Low & High & Med & Low & Low \\
\hline Awnings & $\$ 2-\$ 37$ & $\$ 90$ per unit & $0.0-0.7$ & Low & Low & Low & High & High & Low & Med \\
\hline \multicolumn{11}{|c|}{ Window and Door Measures } \\
\hline $\begin{array}{l}\text { Window Replaced } \\
\text { Conduction } \\
\text { Savings, Fuel Heat }\end{array}$ & not available & $\$ 144-\$ 172$ & $0.20-0.68$ & $\begin{array}{l}\text { Low } \\
\text { (if vinyl) }\end{array}$ & Low & Low & High & Med & Low & High \\
\hline
\end{tabular}

1) See Figure 3.1 for definitions of sensitivity parameters

2) See Appendix A for assumptions regarding installation costs, energy costs, equipment lifetime, and sensitivity issues 
Table 3.1.f Performance summary of warm climate efficiency measures for low-income homes (Cont'd)

\begin{tabular}{|c|c|c|c|c|c|c|c|c|c|c|}
\hline Measure & $\begin{array}{c}\text { 1st Year Savings } \\
\text { (kWh, MBtu, \%, \$) }\end{array}$ & $\begin{array}{l}\text { Installation } \\
\text { Cost } \\
\text { (\$) }\end{array}$ & $\begin{array}{c}\text { SIR } \\
\left(*^{*}=\text { cooling only }\right)\end{array}$ & $\begin{array}{r}\text { Maintenance } \\
\text { Requirements } \\
\text { (Lo/Med/Hi) } \\
\end{array}$ & $\begin{array}{c}\text { Customer } \\
\text { Interaction } \\
\text { (Lo/Med/Hi) }\end{array}$ & $\begin{array}{c}\text { Customer } \\
\text { Education } \\
\text { (Lo/Med/Hi) }\end{array}$ & $\begin{array}{c}\text { Climate } \\
\text { (Lo/Med/Hi) }\end{array}$ & $\begin{array}{l}\text { Bldg. Chars } \\
\text { (Lo/Med/Hi) }\end{array}$ & $\begin{array}{c}\text { Occupancy } \\
\text { (Lo/Med/Hi) }\end{array}$ & $\begin{array}{c}\text { Confidence } \\
\text { Level } \\
\text { (Lo/Med/Hi) }\end{array}$ \\
\hline $\begin{array}{l}\text { Window Replaced } \\
\text { Conduction } \\
\text { Savings, Elec. Heat }\end{array}$ & not available & $\$ 144-\$ 172$ & $0.26-1.38$ & $\begin{array}{l}\text { Low } \\
\text { (if vinyl) }\end{array}$ & Low & Low & High & Med & Low & High \\
\hline $\begin{array}{l}\text { Window Replaced } \\
\text { Infiltration Savings, } \\
\text { Fuel Heat }\end{array}$ & not available & $\$ 144-\$ 172$ & $0.45-1.44$ & $\begin{array}{l}\text { Low } \\
\text { (if vinyl) }\end{array}$ & Low & Low & High & Med & Low & Med \\
\hline $\begin{array}{c}\text { Window Replaced } \\
\text { Infiltration Savings, } \\
\text { Elec. Heat }\end{array}$ & not available & $\$ 144-\$ 172$ & $0.64-3.62$ & $\begin{array}{c}\text { Low } \\
\text { (if vinyl) }\end{array}$ & Low & Low & High & Med & Low & Med \\
\hline $\begin{array}{l}\text { Storm Windows } \\
\text { Conduction } \\
\text { Savings }\end{array}$ & $\$ 1-\$ 4$ & $\$ 50$ & $0.20-0.98$ & Med & Med & Med & High & Med & Low & High \\
\hline $\begin{array}{l}\text { Storm Windows } \\
\text { Infiltration Savings }\end{array}$ & $\$ 1-\$ 7$ & $\$ 50$ & $0.31-1.59$ & Med & Med & Med & High & Med & Low & Med \\
\hline Door Replacement & not available & $>\$ 200$ & not available & Low & Low & Low & Med & Med & Low & Low \\
\hline \multicolumn{11}{|c|}{ Appliance Measures } \\
\hline $\begin{array}{l}\text { Refrigerator } \\
\text { Replacement }\end{array}$ & $\begin{array}{c}355-1,264 \mathrm{kWh} \\
\$ 28-\$ 101\end{array}$ & $\$ 500$ & $0.63-2.27$ & Med & Med & Low & Low & Low & Low & High \\
\hline $\begin{array}{c}\text { Refrigerator Tune- } \\
\text { Up }\end{array}$ & $\begin{array}{c}32-59 \mathrm{kWh} \\
\$ 3-\$ 5\end{array}$ & $\$ 35$ & $0.16-0.27$ & Med & Low & Med & Low & Low & Low & Low \\
\hline $\begin{array}{c}\text { Horizontal Axis } \\
\text { Washers }\end{array}$ & $50 \%-70 \%$ & $\begin{array}{l}\$ 200 \text { above } \\
\text { conventional }\end{array}$ & not available & Low & High & High & Low & Low & Med & Low \\
\hline Microwave Dryers & $10 \%-15 \%$ & $\mathrm{n} / \mathrm{a}$ & not available & Low & High & High & Low & Low & Med & Low \\
\hline \multicolumn{11}{|c|}{ Heat Recovery Measures } \\
\hline Dryer Vents & not available & $\$ 15-20$ & not available & Low & Low & Low & Low & Low & Low & Low \\
\hline
\end{tabular}

1) See Figure 3.1 for definitions of sensitivity parameters

2) See Appendix A for assumptions regarding installation costs, energy costs, equipment lifetime, and sensitivity issues 


\subsection{SUMMARY}

This review of warm climate low-income efficiency measures covers both current weatherization and efficiency practices in warm climate states, as well as past and current research findings on measures potentially applicable in these regions. The information provided here summarizes these experiences and supplies the reader with a plethora of references, located in the Appendix, for further insight.

Attempts have been made to determine estimates of cost effectiveness in the form of savings-toinvestment ratios (SIRs). They are meant to be broad guidelines to implementation and not definitive standards. Many factors are involved in their determination, any number of which may vary on the local level. Costs assumed in their computation have been indicated, allowing the user to adjust the SIR's to reflect these potential differences. If savings impact only one fuel type, an adjustment for differing fuel prices could also be implemented. However, other factors are not as easily handled. Often averages over orientation, other building characteristics, or occupant life style have been used, which would require a more detailed effort to change.

Ideally, the reader will use Table 3.1 to make an initial evaluation of possible measures. Next, it is highly recommended that Appendix $\mathrm{A}$ be referred to for additional information, particularly if Table 3.1 indicates a broad range of SIRs or a high dependence on any of the indicators. Special consideration might also be given to those measures having a low confidence rating on their predicted performance. Data in Appendix A should also be used to provide a cursory ranking of selected measures for the climate of interest.

\subsection{REFERENCES}

DOE, "Insulation Fact Sheet," DOE/CE-0180, January 1988.

EIA, 1993, Household Energv Consumption and Expenditures 1990, Energy Information Administration, DOE/EIA-0321 (90), February 1993. 


\section{APPENDIX A}

\section{Detailed Description of Retrofit Technologies}

This appendix contains detailed information and source references for each measure reviewed. Sources include documented engineering estimates, vendor information, reported performance from research and field tests, and direct discussions with researchers, vendors and field practitioners. Estimated savings are extrapolated from reported energy savings and applied to the end-use energy consumption for low-income homes reported by the Energy Information Administration.

Attempts have been made to determine estimates of cost effectiveness in the form of savings-to-investment ratios (SIRs). They are meant to be broad guidelines to implementation and not definitive standards. Many factors are involved in their determination, any number of which may vary on the local level. Costs assumed in their computation have been indicated, allowing the user to adjust the SIR's to reflect these potential differences. If savings impact only one fuel type, an adjustment for differing fuel prices could also be implemented. However, other factors are not as easily handled. Often averages over orientation, other building characteristics, or occupant life style have been used, which would require a more detailed effort to change.

Tables throughout the Appendix give measure-specific data by climate region, as depicted in Figure A.0 below. The "dry" region referred to in the text combines the "desert" and "arid" regions of the figure.

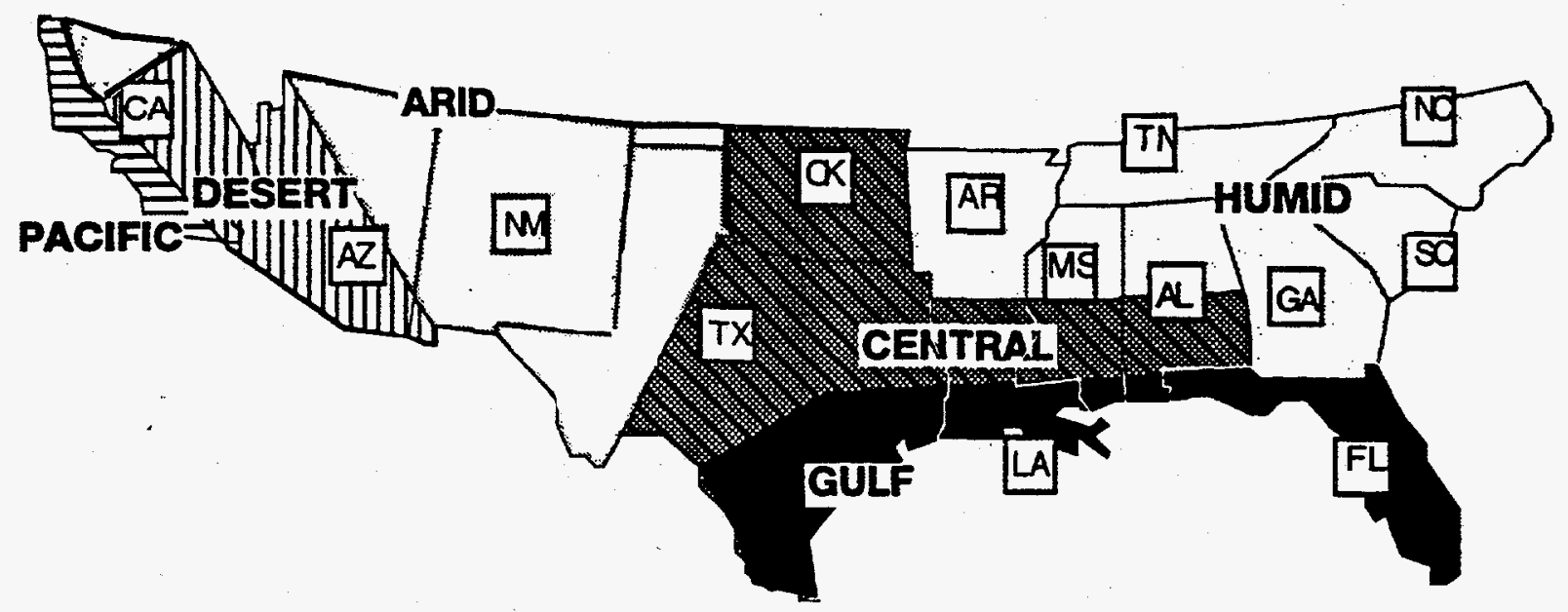

Figure A.0. Warm climate regions of the Weatherization Program

Table A.0 lists energy end-use data for the climate regions, as derived from 1990 Energy Information Administration data (EIA 1993). Only households with annual income below $125 \%$ of the federal poverty level are considered. 
Table A.0. Energy consumption in Mbtu's by end-use and climate region for low-income households

\begin{tabular}{||l|r|r|r|r|r||}
\hline & Heating & Cooling & Water Heating & Appliances & Refrigerator \\
\hline Gulf & 16.0 & 9.5 & 16.0 & 17.7 & 6.7 \\
\hline Humid & 27.4 & 4.6 & 10.8 & 15.9 & 5.1 \\
\hline Dry/Central & 29.5 & 5.6 & 16.3 & 16.9 & 5.8 \\
\hline Pacific & 11.4 & 1.1 & 18.0 & 12.1 & 3.6 \\
\hline
\end{tabular}

\section{References}

EIA, 1993, Household Energy Consumption and Expenditures 1990, Energy Information Administration, DOE/EIA-0321 (90), February 1993. 


\section{AIR-CONDITIONING REPLACEMENT}

\section{Technology Description}

Energy consumed by air-conditioners in warm climate low-income homes accounts for between $2 \%$ and $15 \%$ of total annual energy consumption (EIA 1993). The potential exists for reducing cooling energy consumption and costs through the replacement of older inefficient air-conditioners with new energy-efficient units, in climates with considerably high cooling demands.

Central air-conditioners are rated using the SEER (as of 1992), or Seasonal Energy Efficiency Ratio. With the National Energy Efficient Appliances Act of 1992, manufacturers were prohibited from building systems with efficiency ratios less than 10. Existing equipment installed in the 1970's will have SEER's ranging from 4.5 to 8.0 (Krigger 1994). Today, however, single-speed systems are available with SEER's of 12 and two-speed systems have SEER's greater than 14.0. Variable speed systems offer SEER's up to 15.5, but tend to perform similarly or worse than single speed units during peak loading conditions (Henderson 1990). Because replacement costs of high-efficiency central units are high $(\$ 1,000-\$ 2,000)$, care should be taken to properly size the replacement equipment to prevent the purchase of unnecessary capacity (Parker et al. 1992). A variable speed air-conditioner may cost $\$ 2,500$ more than a typical high-efficiency unit, and is not recommended for use in the weatherization program.

Room or window air-conditioners are rated using the EER, or Energy Efficiency Ratio. Room units can range in size from $1 / 2$ tons to $12 / 3$ tons. The National Appliances act has mandated that room units built after 1990 must have an EER of 8.5 or more. Highest efficiency models will have EER's of 12 (Wynn 1994). Most likely auditors will find units with EER's of 6 or less in the field. Replacement costs (materials and labor) have ranges of $\$ 300-500$ for smaller units, $\$ 600-\$ 750$ for mid-sized units, and $\$ 900-\$ 1,100$ for larger units (Sharp 1994).

A pertinent issue for warm climate regions is the dehumidification potential of replacement air conditioning equipment. The term 'Sensible Heat Ratio' indicates the fraction of total heat removed by the system that is sensible. From this ratio, the fraction of latent heat removal may be determined. Sensible heat ratios of 0.75 or lower and proper machine sizing are both vital to effective moisture removal in these climates (Khattar 1985). Two-speed and variable speed units are generally superior in this regard and blower fan speed can be used to regulate dehumidification (Henderson 1990).

\section{Performance / Field Studies}

\section{Oklahoma Field Test}

Very few studies have been performed investigating the impact of window air-conditioning change out on cooling energy savings. One study of interest concerns low-income homes in Oklahoma, retrofitted under DOE's Weatherization Program (Ternes 1992). The average floor area of these homes was $1,250 \mathrm{ft}^{2}$. Old window airconditioners (average size of $11 / 4$ tons) located in 12 of the homes in the program were replaced with new energy-efficient units. The average EER of the pre-retrofit units was 7 while the EER of the new units was 11 . Average annual pre-retrofit air-conditioning consumption was $1,664 \mathrm{kWh}$, with a range of 8 to $5,708 \mathrm{kWh}$. Annual savings were found to average $535 \mathrm{kWh}$, which represents a $33 \%$ reduction in cooling energy consumption. The study found that savings were much larger for clients with higher initial cooling consumption $(>2,750 \mathrm{kWh})$, at $1,500 \mathrm{kWh}$, a $41 \%$ reduction in cooling consumption. With energy costs in Oklahoma at $7 \mathrm{c} / \mathrm{kWh}$, average savings in annual energy costs were $\$ 38$ for average users, and $\$ 107$ for the larger users. The lifetime for the room air-conditioning unit is approximately 15 years. 


\section{Austin Field Test}

A field test was performed on the replacement of central units in twelve single-family homes in Austin, Texas (Burns 1991). The average floor area of the homes was $1,500 \mathrm{ft}^{2}$. Nine out of the twelve central units replaced were also downsized by $20 \%$, to more correctly match the air-conditioning load of the building. SEER's for the sample improved from 6.5 to 11.5 (Hough 1990). The average annual cooling energy consumption for these homes was $4,677 \mathrm{kWh}$, with a range of $2,200 \mathrm{kWh}$ to $8,700 \mathrm{kWh}$. The average amount of energy saved corresponding to the downsizing and efficiency increase of the replacement units was $1,595 \mathrm{kWh}$ per year, a $34 \%$ reduction. With an average electrical energy cost of $8 \mathrm{k} / \mathrm{kWh}$, annual energy cost savings were $\$ 130$. While the project offered cash refunds to both homeowners and dealers, no data were available on material and installation costs. Average equipment lifetime was expected to be approximately 15 years.

\section{Other Considerations}

- The high cost of replacements (easily $\$ 500+$ per site for window air conditioners and $\$ 1,500+$ for central systems) may make them impractical except for high air-conditioning users, e.g. $2700 \mathrm{kWh}$ to $3600 \mathrm{kWh}$ per year (Ternes 1992). Such households can likely be identified by comparing the magnitude of the difference in the July and August utility bills with those of April and October. Some consideration may be necessary to account for low-income home owners whose air-conditioning energy costs are low because they cannot afford operating old, inefficient units.

- In order of increasing cooling demand are the Pacific, Dry/Central, Humid and Gulf regions. In these regions, on average, $44 \%$ of the homes have window-type air-conditioning, $22 \%$ have central-type systems, and $34 \%$ have no mechanical cooling whatsoever (Situation Analysis 1995).

- The components of central split air-conditioning systems (indoor air-coils and outdoor condensing units), should be replaced concurrently to maintain designed efficiency levels.

\section{Estimates of Potential Savings}

Table A.1. Cooling energy and cost savings from air-conditioner replacement

\begin{tabular}{|c|c|c|c|c|}
\hline \multirow[b]{2}{*}{ Climate Region } & \multicolumn{2}{|c|}{ Window A/C Replacement } & \multicolumn{2}{|c|}{$\begin{array}{c}\text { Central A/C Replacement } \\
\text { and Downsizing }\end{array}$} \\
\hline & $\begin{array}{c}\text { Cooling Savings, } \\
\text { kWh } \\
\$ / y \mathbf{r}\end{array}$ & SIR cool & $\begin{array}{c}\text { Cooling Savings, } \\
\text { kWh } \\
\text { \$/yr }\end{array}$ & SIR cool \\
\hline Humid & $\begin{array}{l}432 \\
\$ 35\end{array}$ & 0.66 & $\begin{array}{l}432 \\
\$ 35\end{array}$ & 0.25 \\
\hline Gulf & $\begin{array}{l}891 \\
\$ 71\end{array}$ & 1.3 & $\begin{array}{l}891 \\
\$ 71\end{array}$ & 0.53 \\
\hline Dry & $\begin{array}{l}513 \\
\$ 41\end{array}$ & 0.77 & $\begin{array}{l}513 \\
\$ 41\end{array}$ & 0.31 \\
\hline Central & $\begin{array}{l}513 \\
\$ 41\end{array}$ & 0.77 & $\begin{array}{l}513 \\
\$ 41\end{array}$ & 0.77 \\
\hline Pacific & $\begin{array}{l}103 \\
\$ 8\end{array}$ & 0.15 & $\begin{array}{l}103 \\
\$ 8\end{array}$ & 0.06 \\
\hline
\end{tabular}

1) Based on a $33 \%$ savings extrapolated from results of field tests, and EIA A/C consumption

2) Window unit cost $\$ 600$, central units cost $=\$ 1,500$

3) Cost Savings based on electricity costs of $8 \mathrm{c} / \mathrm{kWh}$ 


\section{References}

Burns, R and Hough, RE. Monitoring and Evaluation of Replacing Low-Efficiency Air Conditioners with HighEfficiency Air Conditioners in Single-Family Detached Houses in Austin. Texas, ORNL/Sub/86-SA566/V, Oak Ridge National Laboratories, Oak Ridge, TN, August, 1991.

EIA, 1993, Household Energy Consumption and Expenditures 1990, Energy Information Administration, DOE/ELA-0321 (90), February 1993.

Hammerlund, J., Proctor, J., Kast, G. and Ward, T., 1992. "Enhancing the Performance of HVAC and Distribution Systems in Residential New Construction," 1992 ACEEE Summer Study on Energy Efficiency in Buildings, Vol. 2, American Council for an Energy Efficient Economy, Washington D.C.

Henderson, H.I., 1990. "A Side by Side Field Test of Variable Speed and Constant Speed Air Conditioners," ASHRAE Transactions, Vol. 96, Pt. 1, American Society of Heating, Refrigerating and Air Conditioning Engineers, Atlanta, GA.

Hough, R., Burns, P., 1990. "Effectiveness of an Air Conditioner Replacement Program in Austin, Texas," ASHRAE Transactions, Vol. 96, Pt. 2, American Society of Heating, Refrigerating and Air Conditioning Engineers, Atlanta, GA.

Houghton, D.J., Bishop, R.C., Lovins, A.B. and Stickney, B.L., 1992. Space Cooling and Air Handling, Technology Atlas, E-Source, Inc., Boulder, CO.

Jenkins, V., 1991. "Heat Pump Study: Tricks of the Trade That Can Pump Up Efficiency," Home Energy Magazine, Vol. 8, No. 2, March/April.

Khattar, M., Ramanan, N. and Swami, M., 1985. "Fan Cycling Effects on Air Conditioner Moisture Removal Performance in Warm, Humid Climates," International Symposium on Moisture and Humidity, FSEC-PF-75-85, Florida Solar Energy Center, Cape Canaveral, FL.

Krigger, J., 1994. Residential Energy: Cost Savings and Comfort for Existing Buildings, Saturn Resource Management, Helena, MT.

Neal, L., 1992. "Air-Conditioner Efficiency in the Real World," Home Energy Magazine, Vol. 9, No. 3, May/June.

Parker, D., Fairey, P., Gueymard, C., McCluney, R., Mcllvaine, J. and Stedman, T., 1992. Rebuilding for Efficiency: Improving the Energv Use of Reconstructed Residences in South Florida, FSEC-CR-562-92, Florida Solar Energy Center, Cape Canaveral, FL.

Proctor, J. and Pernick, R.K., 1992. "Getting it Right the Second Time: Measured Savings and Peak Reduction from Duct and Appliance Repairs," 1992 ACEEE Summer Study on Energy Efficiency in Buildings, Vol. 2, American Council for an Energy Efficient Economy, Washington D.C.

Situation Analysis, 1995, "U.S. DOE Warm Climate Initiative: Situation Analysis," DRAFT, February 1995.

Sharp, T., 1992. The North Carolina Field Test: Field Performance of the Preliminary Version of an Advanced Weatherization Audit for the Department of Energy's Weatherization Assistance Program, ORNL/CON-362, 
Oak Ridge National Laboratory, Oak Ridge, TN, June, 1994.

Ternes, M. P. and Levins, W. P. Oklahoma Field Test: Air Conditioning Electricity Savings from Standard Energy Conservation Measures, Radiant Barriers and High-Efficiency Window Air Conditioners, ORNL/CON317, Oak Ridge National Laboratory, Oak Ridge, TN, August, 1992.

VTEC Laboratories, Inc. "Hydrophilic Membrane Air Conditioning," Technical Proposal to the New York State Energy Research and Development Authority, October 17, 1994.

Wym, S., 1994. "The Most Energy-Efficient Room Air Conditioners for 1994," FSEC-GP-56-94, Florida Solar Energy Center, Cape Canaveral, FL. 


\section{ATTIC VENTILATION}

\section{Technology Description}

Additional attic ventilation is a commonly advocated method used to reduce ceiling summer heat gains in residential buildings. Increased passive attic ventilation (wind and buoyancy driven ventilation) can be obtained by expanding the free inlet and outlet areas within the attic, or by adding a ridge vent to take advantage of the stack effect. The Florida Solar Energy Center estimates costs for these passive measures at \$50, with a lifetime of 15 years (Cummings 1989). Addition of rotary turbine vents is readily feasible with existing construction, however, these have largely fallen out of favor in recent years due to long-term reliability problems. Although various means of augmenting passive ventilation are useful for new construction, increasing attic ventilation rates in existing buildings is generally accomplished by adding forced ventilation using attic fans which are temperature activated. Regardless of whether forced or passive techniques are employed, increasing any form of ventilation beyond 2.5 ACH seems to provide little additional cooling relief (Cummings 1989).

Forced attic ventilation could be feasibly added to most attic systems, but poor performance and unattractive economics serve as the main limitation to common usage as a weatherization measure. Perhaps the only means to further improve the effectiveness of this measure is with more efficient fan motors which might reduce parasitic energy use. Another possibility might be the use of photovoltaics to power ventilation fans. Although technically feasible, neither improvement would likely be economically feasible.

Other than questionable performance, there are other potential problems with powered attic ventilation. In recent work, Tooley and Davis (1994) have found that power attic ventilation can effectively cause negative pressures in combustion appliance zones-- a potentially dangerous situation-- as well as drawing conditioned air from the building interior through leakage in the ceiling/attic interface. This could serve to increase building cooling latent loads and offset any potential energy savings associated with powered attic ventilation.

DOE guidelines from The Insulation Fact Sheet (1988), recommend adequate attic ventilation be provided to insulated attics to prevent moisture accumulation. The report suggests supplementing passive gable vents with soffit vents and ridge vents. In order to provide sufficient ventilation, DOE suggests installing approximately $1 \mathrm{ft}^{2}$ of venting for each $150 \mathrm{ft}^{2}$ of attic floor area.

\section{Performance/Field Studies}

Forced attic ventilation is a commonly encouraged technique to reduce residential heat gains from the ceiling. However, even those who are in favor of increased attic ventilation have often warned that the energy consumption associated with the attic fan motor is likely greater than any realized energy savings from its use (Wolfert and Hinrichs 1974). An early detailed study has showed that while forced attic ventilation did reduce cooling energy use, the reduction was quite small and outweighed by the energy consumption of the fan itself (Dutt and Harrje 1979). Another study in two instrumented side-by-side homes in Texas came to similar conclusions (Burch and Treado 1979). Forced ventilation was found to reduce ceiling heat gain by $1.1 \mathrm{Btu} / \mathrm{hr} / \mathrm{ft}^{2}$ $(328 \mathrm{~W})$ over soffit venting, and gains to the attic duct system by $94 \mathrm{~W}$. At a normal air conditioning COP of 3 , the overall reduction in cooling energy use could be expected to be approximately $140 \mathrm{~W}$. With the measured consumption of $284 \mathrm{~W}$ by the ventilation fan, savings were negated for this effort. Measured reduction to the maximum cooling load was only $6 \%$ for $R-11$ ceiling insulation. Thus, the powered ventilation does not typically result in a net energy savings unless the attic is not insulated.

Interestingly, Burch and Treado (1979) found ridge or turbine ventilation to be nearly as effective as forced ventilation in reducing the overall attic temperature profile, producing a an average reduction in the ceiling heat 
flux of about $19 \%$. Still, the authors concluded that this represented no more than a $3 \%$ reduction in the overall building cooling load under maximum conditions.

While additional cooling energy savings are possible with powered forced ventilation, cost savings will usually only be possible for photovoltaic powered fans. A typical attic fan, installed, can be assumed to cost approximately $\$ 200$ and will only provide energy or cost savings in homes without ceiling insulation. Although use of photovoltaic powered forced ventilation would likely yield a net reduction in energy use, the modest savings could not effectively offset its high cost of $\$ 800$. For instance, if using the above calculation of a 140 W peak AC savings, and optimistically allowing for the fact that the average daily reduction may be one third of this figure, the total energy savings over a six month cooling season would total only about $200 \mathrm{kWh}$ or about $\$ 16$. Average lifetime for these forced ventilation measures is 10 years.

\section{Other Considerations}

These results indicate that other means of controlling attic heat gain are preferable and more cost effective than forced ventilation, and other analyses tend to verify this conclusion. Detailed simulations suggest that the heat transfer in an attic to a residential building interior in mid-summer is dominated by radiative gains from the hot roof decking directly to the insulation surface (Parker et al. 1991; Wilkes 1991). This mode of heat transfer is more effectively limited by 1) increased attic insulation, 2) a truss-mounted radiant barrier or 3) a white reflective roof surface that limits solar gain to the attic structure.

\section{Estimates of Potential Savings}

Table A.2. Cooling energy and cost savings, and SIR's for attic ventilation measures

\begin{tabular}{|c|c|c|c|c|}
\hline \multirow[b]{2}{*}{ Climate Region } & \multicolumn{2}{|c|}{$\begin{array}{l}\text { Passive Ventilation } \\
(\sim 3 \% \text { cooling savings })\end{array}$} & \multicolumn{2}{|c|}{$\begin{array}{l}\text { Solar Forced Ventilation } \\
\text { ( } \sim 6 \% \text { cooling savings) }\end{array}$} \\
\hline & $\begin{array}{c}\text { Cooling Savings, } \\
\text { kWh, \$/yr }\end{array}$ & SIR cool & $\begin{array}{l}\text { Cooling Savings, } \\
\text { kWh, } \$ / \mathbf{y r}\end{array}$ & SIR cool \\
\hline Humid & $\begin{array}{c}40 \mathrm{kWh} \\
\$ 3\end{array}$ & 0.68 & $\begin{array}{l}81 \mathrm{kWh} \\
\$ 6\end{array}$ & 0.06 \\
\hline Gulf & $\frac{83 \mathrm{kWh}}{\$ 6}$ & 1.36 & $\begin{array}{l}167 \mathrm{kWh} \\
\quad \$ 13\end{array}$ & 0.13 \\
\hline Dry & $\begin{array}{c}48 \mathrm{kWh} \\
\$ 4\end{array}$ & 0.9 & $\begin{array}{c}96 \mathrm{kWh} \\
\$ 8\end{array}$ & 0.08 \\
\hline Central & $\begin{array}{l}48 \mathrm{kWh} \\
\$ 4\end{array}$ & 0.9 & $\begin{array}{c}96 \mathrm{kWh} \\
\$ 8\end{array}$ & 0.08 \\
\hline Pacific & $\begin{array}{c}10 \mathrm{kWh} \\
\$ 1\end{array}$ & 0.22 & $\begin{array}{c}19 \mathrm{kWh} \\
\$ 2\end{array}$ & 0.02 \\
\hline
\end{tabular}

1) Cost savings are based on electrical energy costs of $8 c / \mathrm{kWh}$

2) Extrapolated from literature references, and EIA A/C consumption data

3) Passive ventilation lifetime: 15 years, forced ventilation lifetime: 10 years

\section{References}

Burch, D.M. and Treado, S.J., 1979. "Ventilating Residences and their Attics for Energy Conservation-- An Experimental Study," in Summer Attic and Whole House Ventilation, National Bureau of Standards Special Publication 548, Washington D.C. 
Cummings, J., Tooley, J., Moyer, N., 1989. Florida Fix Weatherization Training Manual, FSEC-GP-42-89, Florida Solar Energy Center, Cape Canaveral, FL.

DOE, "Insulation Fact Sheet," DOE/CE-0180, January 1988.

Dutt, G.S. and Harrje, D.T., 1979. "Forced Ventilation for Cooling Attics in Summer," in Summer Attic and Whole House Ventilation, National Bureau of Standards Special Publication 548, Washington D.C.

Parker, D.S., Fairey, P.F., Gu, L., 1991. "A Stratified Air Model for Simulation of Attic Thermal Performance," Insulation Materials: Testing and Applications, ASTM STP 1116, American Society of Testing and Materials, Philadelphia, PA.

Schaeffer, J. 1994. Alternative Energy Sourcebook, 8th Ed., Real Goods Trading Co., Ukiah, CA.

Tooley, J.J. and Davis, B.E., 1994. "Powered Attic Ventilators, Another Building Science Nightmare and Treasure Trove," Proceedings of the 1994 Summer Studv on Energy Efficiency in Buildings, Vol. 5, American Council for an Energy Efficient Economy, Washington D.C.

Wilkes, K.E., 1991. Thermal Model of Attic Systems with Radiant Barriers, ORNL/CON-262, Oak Ridge National Laboratories, Oak Ridge, TN.

Wolfert, C.K. and Hinrichs, H.S., 1974. Fundamentals of Residential Attic Ventilation, H.C. Products Company, Princeville, IL. 


\section{CEILING FANS}

\section{Technology Description}

Use of natural ventilation and fans for cooling is a time-honored means of reducing air conditioning energy needs in southern climates (Givoni 1976). Optimally, the building is designed for natural ventilation and ceiling and/or portable fans provide increased localized air movement to promote thermal comfort. Since alteration of window location is beyond the realm of weatherization improvements, addition of ceiling or portable fans are appropriate measures to decrease energy use. Also, addition of a screen front door may greatly enhance ventilation and provide additional occupant comfort.

There are at least two modes in which ceiling fans can be used. In the first, where air conditioning is unavailable, adding ceiling fans may significantly improve building comfort and health although actually increasing energy use. However, the more commonly considered case is where ceiling fans are used with the objective of providing a higher cooling system thermostat set point with acceptable comfort. Fans can also potentially avoid the use of air conditioning during "swing" seasons.

Two other important factors must be taken into account in assessing the benefits of fans: their actual energy use and the added internal heat gains produced by the fans during operation. The measured electrical demand of ceiling fans varies between 5 and 115 Watts depending on model and speed selection. A power demand of 40 $\mathrm{W}$ at medium speed is probably about average (Chandra 1985). Thus, a fan used for six months of the year would use $175 \mathrm{kWh}$. Also, all of the energy use of the fan is eventually converted to heat within the home which must eventually be removed by ventilation air or the cooling system. Both of these energy losses must be properly accounted for in order to properly determine the net energy savings from fans.

Ceiling and portable fans are readily available and their characteristics are well understood. Although the technology is mature, improvement of fan motor efficiency may be a possible goal. Currently, manufacturers do not provide information on energy consumption of fans at various speeds, nor their efficiencies in air circulation. This could be made readily available by simple tests which would determine fan power consumption and achieved air velocities under reference conditions.

\section{Performance / Field Studies}

The ability of ceiling fans to improve comfort during the cooling season is well documented (Rohles et al. 1983; Fairey et al. 1986). Although studies commonly suggest a $2-6^{\circ} \mathrm{F}$ increase in the thermostat set point, data from 384 surveyed Central Florida households suggests that only the low end of this range can be justified (Vieira and Parker 1991). ${ }^{1}$ Studies touting potential cooling savings of up to $40 \%$ have usually been sponsored by fan manufacturers (e.g. A.D. Little 1981). These often make unrealistic assumptions such as presuming that occupants are within four feet of a fan at all times with only one fan in use, and a $6^{\circ} \mathrm{F}$ elevation of the thermostat setting.

A recent environmental chamber study by Consumer Reports showed that the long-reported destratification benefits when heating are largely apocryphal (Consumer Reports 1993). Thus, benefits from ceiling fansi can only reduce cooling needs.

\footnotetext{
${ }^{1}$ Central Florida homeowners owning and always using ceiling fans reported a $2.1^{\circ} \mathrm{F}$ higher cooling system set point $\left(78.2^{\circ} \mathrm{F}\right)$ than the other group who did not have ceiling or portable fans $\left(76.1^{\circ} \mathrm{F}\right)$. Furthermore, analysis of variance showed a relationship between frequency of ceiling fan use and thermostat set point that was significant at a greater than $99 \%$ confidence level (Vieira and Parker, 1991.)
} 
A simulation estimating the savings of ceiling and whole house fans was performed by the Florida Solar Energy Center (FSEC). The study assumed that installation of ceiling fans allowed the building cooling thermostat setting to be elevated by $2{ }^{\circ} \mathrm{F}$ when the occupants were home. Such an analysis, performed for Miami, showed the measure to produce net cooling energy savings (less that of the fans themselves) of $12 \%$ or $735 \mathrm{kWh}$ (Parker et al. 1992). ${ }^{2}$ At $\$ 0.08 / \mathrm{kWh}$ the payback from the savings from ceiling fans would approach the useful life of the fans (10 years). Utility peak savings may be low or even negative. Of course, results will likely vary significantly by climate. Also, realized savings may be significantly lower since recent interview data collected from low income homes in South Florida suggests that many ceiling fans are used 24-hours a day all year whether cooling is needed or not.

\section{Other Considerations}

Although fans have been used in homes for generations and simulations exist to estimate their benefit, actual savings from their use as an energy efficiency measure is undemonstrated. Adding ceiling or portable fans will likely do more to improve cooling comfort than it will to produce energy savings. This is due to use habits and the potential "take back" effect (homeowners often opt for greater comfort rather than a higher cooling set point).

Addition of ceiling or portable fans to homes is a readily available weatherization measure. However the applicability may be effected by the pre-existing saturation of fans. FSEC's survey of 384 existing households found only $5 \%$ of homes did not have ceiling or portable fans with the average home possessing 4.5 fans. Data from the EIA for two states in the southeast shows that ceiling fan saturation is greater than $60 \%$ for much of Texas and greater than $40 \%$ for most of North Carolina.

\section{Estimates of Savings Potential}

The sources reviewed indicate potential savings from installation of ceiling fans of from between 10 to 20 percent of the cooling energy use. The table below summarizes the economics of the measure based on net cooling energy savings of $12 \%$. Cooling energy consumptions for the climate subregions are taken from the 1990 EIA data (EIA 1993). The cost of fan installation assumes use of 4 fans per home at an installed cost of $\$ 100$ per fan. This may vary considerable from house to house and geographical location. Also assumed are an electric rate of $\$ .08 / \mathrm{kWh}$ and useful life of 10 years.

\footnotetext{
${ }^{2}$ Within the simulation, the cooling thermostat setting was increased from $78^{\circ}$ to $80^{\circ} \mathrm{F}$. The house was assume to be occupied between $5 \mathrm{PM}$ and $8 \mathrm{AM}$ on weekdays and all day on weekends. The analysis assumed that the fans were on an average of eight hours per day, drawing 30 watts each. This electricity consumption ( $44 \mathrm{kWh} / \mathrm{month}$ ) was added to the DOE $2.1 \mathrm{D}$ estimated cooling energy use. The building's internal heat gains were also increased by $205 \mathrm{Btu} / \mathrm{hr}$ to account for the additional heat released from operation of the fans.
} 
Table A.3. Energy and cost savings, and SIR's for ceiling fan installation

\begin{tabular}{|c|c|c|}
\hline $\begin{array}{c}\text { Climate } \\
\text { Region }\end{array}$ & $\begin{array}{c}\text { Cooling } \\
\text { Savings, } \\
\mathbf{k W h}, \mathbf{\$ y r}\end{array}$ & SIR cool \\
\hline Humid & $162 \mathrm{kWh}, \$ 13$ & 0.26 \\
\hline Gulf & $334 \mathrm{kWh}, \$ 27$ & 0.55 \\
\hline Dry/Central & $197 \mathrm{kWh}, \$ 16$ & 0.32 \\
\hline Pacific & $39 \mathrm{kWh}, \$ 3$ & 0.06 \\
\hline
\end{tabular}

\section{References}

A.D. Little, 1981. Energy Savings Resulting from the Use of a Hunter Ceiling Fan, Phase II Final Report, prepared for Ribbins and Meyers, Inc., Cambridge, MA.

Burch, D.M. and Treado, S.J., "Ventilating Residences and their Attics for Energy Conservation," in Summer Attic and Whole House Ventilation, NBS Special Publication 548, National Bureau of Standards, Washington D.C., 1979.

Chandra, S., 1985. "Fans to Reduce Cooling Costs in the Southeast," FSEC-EN-13-85, Florida Solar Energy Center, Cape Canaveral, FL.

Consumer Reports, 1993. "Ceiling Fans," Consumer Reports, June, 1993.

EIA, 1993, Household Energy Consumption and Expenditures 1990, Energy Information Administration, DOE/EIA-0321 (90), February 1993.

Fairey, P., Chandra, S. and Kerestecioglu, A., 1986, Ventilative Cooling in Southern Residences: A Parametric Analvsis, FSEC-PF-108-96, Florida Solar Energy Center, Cape Canaveral, FL.

Givoni, B. 1976, Man, Climate and Architecture, Applied Science Publishers Ltd., London.

Ingley, H.A., Dixon, R.W. and Buffington, D.E., Residential Conservation Demonstration Program, Florida Public Service Commission, University of Florida, Gainesville, FL, 1983.

Parker, D., Fairey, P., Gueymard, C., McCluney, R., Mcllvaine, J. and Stedman, T., 1992. Rebuilding for Efficiency: Improving the Energy Use of Reconstructed Residences in South Florida, FSEC-CR-562-92, Florida Solar Energy Center, Cape Canaveral, FL.

Rohles, F.H., Konz, S.A. and Jones, B.W., 1983. "Ceiling Fans as Extenders of the Summer Comfort Envelope," ASHRAE Transactions, Vol. 89, Pt. 1A, American Society of Heating, Refrigerating and Air Conditioning Engineers, Atlanta, GA.

Vieira, RK. and Parker, D.S., 1991. Energy Use in Attached and Detached Residential Developments, FSEC-CR381-91, Florida Solar Energy Center, Cape Canaveral, FL. 


\section{CEILING / ATTIC INSULATION}

\section{Technology Description}

Insulating attic spaces and ceilings saves energy by reducing heat flow through these surfaces. The same materials and installation methods used in other parts of the country, may be used in warmer climates. Major differences between southem and northern applications involve the amount of insulation to add to existing levels. Most homes without attic insulation should automatically be considered for retrofit. Justification for recommended levels will likely be based largely on achieved heating energy savings as cooling energy savings may not be as significant. However, increased comfort level, during summer months, may add to the value of the retrofit.

DOE guidelines for new construction (also generally applicable to retrofit of existing ceilings when no insulation is currently present) suggest installing at least R-30 ceiling insulation in southern houses, except for homes in the extreme south (southern Florida, Texas, and California) with fossil-fueled heating systems. For these houses, R-19 is recommended (DOE 1988) ${ }^{3}$. A Florida program for new residential construction does not recommend ceiling insulation in southern Florida, but instead recommends "reflective roof surfaces or radiant barriers" (Nisson 1993).

Recommendations for how much insulation to add if insulation presently exists are not as readily available as incremental savings and installation costs must be considered. In this case, audit programs such as the National Energy Audit (NEAT) and ZIPcode are useful for states and agencies to make program decisions using local information at the house level (if desired). The Virginia Weatherization Program recommends bringing the insulation level to R-30 if the existing level is below R-19, based on engineering estimates and field testing (Greely 1992). Georgia Power, through their Super Good Cents Program, recommends increasing attic insulation levels to R-30 for all existing Georgia homes (Tiller 1992). The Florida Weatherization Program gives R-19 attic insulation the highest ranking except for homes with white roofs in the southern third of the state. In these homes, the Program gives priority to other weatherization measures over this option (Cummings 1989).

There is some controversy over the potential hazards of the two most common types of attic insulation, glass fiber and cellulose. A recent study, cited at the Tenth International Conference on Thermal Insulation, showed "good retention of chemical fire retardants and persistence of fire resistance" in an eight-year field test of cellulose insulation, although "some unexplainable test failures and loss of chemical fire retardant from a few test samples" prevents the tests from eliminating all doubt (Nisson 1994). Also, installers of fiberglass insulation should take appropriate precautions to prevent inhalation of the fibers. The American Journal of Industrial Medicine affirms a link between respirable fiberglass fibers and lung cancer, though maintains that there is virtually no risk to home occupants. Installers are advised to take "proper precautions" (Nisson, 1994). New fiberglass products on the market may substantially mitigate this problem. These include batts in bags and a new fiber which produces less dust and whose fiber diameter may render it non-hazardous (Nisson, 1994).

\section{Performance/Field Studies}

The ability of attic insulation to reduce heat losses during the winter are generally acknowledged and can be readily predicted using standard calculation procedures. However, increasing the level of existing ceiling insulation may not produce substantial cooling energy savings even in hot climates. Predicted annual cooling

\footnotetext{
${ }^{3} \mathrm{DOE}$ will be releasing a new Insulation Fact Sheet in 1997. The new information will use updated fuel and materials costs to recommend optimal levels of insulation and include comments on infiltration and moisture concerns.
} 
savings from increasing the insulation level from R-19 to R-30 in a typical 1,500 square foot home are listed in Table A.4, for major cities located in the warm climate states (McLain 1992).

Table A.4. Cooling energy and cost savings associated with increasing insulation levels from R-19 to R-30

\begin{tabular}{|c|c|c||}
\hline Location of Home & $\begin{array}{c}\text { Annual Cooling } \\
\text { Energy Savings } \\
\text { (kWh) }\end{array}$ & $\begin{array}{c}\text { Annual Energy } \\
\text { Cost Savings, @ } \\
\mathbf{8} \mathbf{c} / \mathbf{k W h} \mathbf{( \$ )}\end{array}$ \\
\hline El Toro, CA & 37 & $\$ 2.96$ \\
\hline Atlanta, GA & 65 & $\$ 5.20$ \\
\hline Albuquerque, NM & 69 & $\$ 5.52$ \\
\hline Memphis, TN & 83 & $\$ 6.64$ \\
\hline Lake Charles, LA & 90 & $\$ 7.20$ \\
\hline Houston, TX & 95 & $\$ 7.60$ \\
\hline Ft. Worth, TX & 99 & $\$ 7.92$ \\
\hline Jackson, MS & 100 & $\$ 8.00$ \\
\hline Orlando, FL & 105 & $\$ 8.40$ \\
\hline Fresno, CA & 109 & $\$ 8.72$ \\
\hline El Paso, TX & 110 & $\$ 8.80$ \\
\hline Miami, FL & 119 & $\$ 14.72$ \\
\hline Phoenix, AZ & 184 & \\
\hline
\end{tabular}

Depending on the amount required, installation and material costs for adding ceiling insulation may range from $\$ 300-\$ 500$, at a rate of approximately $25 \mathrm{c} / \mathrm{ft}^{2}$ to $40 \mathrm{c} / \mathrm{ft}^{2}$ (Penn 1992, Randolph 1991, Cummings 1989). The effective lifetime for this measure is 25 years.

\section{Other Considerations}

- Additional experience in the Virginia Weatherization study found that insulation R-values decreased by $50 \%$ when only $5 \%$ of the leaks and bypasses go unsealed (Randolph 1991). The study recommends doing comprehensive sealing work, prior to adding insulation or venting.

- Well-insulated attics should be adequately ventilated to prevent moisture accumulation.

\section{Estimates of Potential Savings}

Table A.5 provides estimates for cooling energy savings based on the study by McLain (1992). The term SIRcool represents the SIR strictly due to cooling energy savings, while the term SIRheat, required is the mininum SIR required from heating savings to make the overall SIR for this measure equivalent to 1.0. 
Table A.5. Cooling energy and cost savings, and SIR's for installation of additional attic insulation.

\begin{tabular}{|c|c|c|}
\hline \multirow[b]{2}{*}{ Climate Region } & \multicolumn{2}{|c|}{ Increase Insulation from R-11 to R-19 } \\
\hline & $\begin{array}{c}\text { Cooling Savings, } \\
\text { kWh } \\
\text { \$/yr }\end{array}$ & $\begin{array}{l}\text { SIR cool, } \\
\text { SIR heat, required }\end{array}$ \\
\hline Humid & $\begin{array}{c}83 \mathrm{kWh} \\
\$ 7\end{array}$ & $\begin{array}{l}0.27 \\
0.73\end{array}$ \\
\hline Gulf & $\begin{array}{c}102 \mathrm{kWh} \\
\$ 8\end{array}$ & $\begin{array}{l}0.33 \\
0.67\end{array}$ \\
\hline Dry & $\begin{array}{c}106 \mathrm{kWh} \\
\$ 9\end{array}$ & $\begin{array}{l}0.35 \\
0.65\end{array}$ \\
\hline Central & $\begin{array}{c}99 \mathrm{kWh} \\
\$ 8\end{array}$ & $\begin{array}{l}0.32 \\
0.68\end{array}$ \\
\hline Pacific & $\begin{array}{c}37 \mathrm{kWh} \\
\$ 3\end{array}$ & $\begin{array}{l}0.12 \\
0.88\end{array}$ \\
\hline
\end{tabular}

1) Cost savings are based on electrical energy costs of $8 \mathrm{~d} / \mathrm{kWh}$

2) Extrapolated from literature reference, and EIA A/C consumption data

3) Insulation lifetime: 25 years, Average cost: $\$ 400$

\section{References}

DOE, "Insulation Fact Sheet," DOE/CE-0180, January 1988.

Cummings, James B., John J. Tooley Jr., and Neil A. Moyer, Florida Fix Weatherization Training Manual, Florida Solar Energy Center, FSEC-GP-42-89, October 1989.

Greely, Kathy, John Randolph, and Bill Hill, "A Warm Wind Blows South: Virginia's Weatherization Evaluation," Home Energy, Jan/Feb 1992, p.15.

McLain, H. A., "Modeling Study of the Cooling Season Performance of Exterior Wall Insulation," Proceedings of the Thermal Performance of the Exterior Envelopes of Buildings V, ASHRAE/DOE/BTECC, p. 655, December, 1992.

Nisson, J.D., Ed., "OSHA Official Says Fiberglass is Comparable to Asbestos as Carcinogen," Energy Design Update, October, 1994.

Nisson, J.D., Ed., "Permanence of Borate Fire Retardants in Cellulose - Eight-year Field Test," Energy Design Update, August, 1994.

Nisson, J.D., Ed., "After the Hurricane: Energy-Retrofitting South Florida," Energy Design Update, April, 1993.

Nisson, J.D., Ed., "A Sober Look at Attic R-Value in Hot Climates," Energy Design Update, February, 1993.

Penn, C., "A Cozier and Cheaper Home: Home Energy's Guide to Insulation," Home Energy Magazine, January/February 1992, Vol. 9, No. 1. 
Tiller, J., 1992. “DSM in Dixie," Home Energy Magazine, January/February 1992, Vol. 9, No. 1.

Randolph, J., Greely, K., Hill, W., "Evaluation of the Virginia Weatherization Program: Final Report," Virginia Association of Community Action Agency, Inc., Richmond VA, March 1991. 


\section{CENTRAL AIR-CONDITIONING TUNE-UP AND REPAIR}

\section{Technology Description}

General tuning and maintenance of air-conditioning systems can improve the efficiency and increase the lifetime of the equipment. Such activities include: proper refrigerant charge, ensuring unobstructed air-flow, and the cleaning of unit coils.

A recent study in California found that $31 \%$ of the air-conditioners tested were charged improperly (Jenkins 1991). Ensuring proper refrigerant charge is essential to maintaining design efficiency over the intended lifetime of the equipment. Overcharging will cause compressors to work harder while undercharging increases run time. Depending on the type of expansion device employed, a system that is $10 \%$ over- or undercharged will experience a reduction in efficiency of $6 \%$ to $8.5 \%$ (for capillary tubes), or of $10 \%$ to $18 \%$ (for thermal expansion valves, TXV's), (Neal 1992).

Cooling capacity and efficiency of air-conditioning systems also depend highly on air flow. Efficiency will suffer if indoor air flow falls below the recommended amount of $400 \mathrm{cfm}$ per ton of capacity. If the indoor air flow is low, filters and coils should be checked and cleaned before increasing fan capacity. It is generally recommended that air filters be replaced every one or two months. Evaporator fan blades, coils and condensate pans should be checked and cleaned every two years (Krigger 1994). Additionally, air flow around condensing units should be unrestricted and coils or fins should be straight and clean.

The cost of tuning up an existing air conditioning system will vary. Cleaning the evaporator coils is a labor intensive task whose cost will depend on the cost of labor as well as whether the coils need to be removed from the unit for proper cleaning. Persistence of measure effectiveness over time remains a significant and unresolved issue in determining overall economics of air conditioner tune-ups. Obviously, the pre-tune-up energy use will also play a role in determining relative cost effectiveness.

\section{Performance / Field Studies}

There are relatively few studies on how air-conditioner tune-ups can improve the performance of existing equipment. Evidence suggests that dirty evaporator coils will reduce residential air-conditioner system efficiency by about $8 \%$ and that filter dust collection could reduce system airflow by up to $1 \%$ per week with a $9 \%-79 \%$ reduction in efficiency (Neal 1990; Houghton et al. 1993). Hammerlund et al. (1992) found that correction of refrigerant charge in Los Angeles single family homes could reduce cooling energy use by an average of $11.5 \%$; and correction of air flow related problems (including replacement of unchanged filters) was shown to improve performance by $9.7 \%$. A similar field study by Pacific Gas and Electric in Central California (Proctor and Pernick 1992) found the correction of system airflow yielding an average savings of $7.7 \%$ and correction of improperly changed units (about half were either over or under charged) yielded cooling energy savings of approximately $11.5 \%$. Estimated heating energy savings were lower than cooling savings, at $2 \%$.

\section{Other Considerations}

- If annual utility bills are available, cooling energy consumption may be estimated by subtracting the energy consumed during a mild-weather month from each of the high cooling months. In order to estimate savings associated with maintenance measures, multiply the cooling consumption by the approximate savings percentages listed in Table A.6. 


\section{Estimates of Potential Savings}

Actual consumption and cost savings were not available in most of the sources listed above. An estimate of potential savings for the five warm climate regions are given below. These estimates are based on cooling consumption data collected from the 1990 EIA residential housing survey (EIA 1993). Cost savings are based an electrical energy cost of $8 \notin / \mathrm{kWh}$. The cost of cleaning the evaporative coils, as well as the savings achieved, will vary depending on the condition of the coils and whether the coils must be removed from the unit. Although the immediate cost-effectiveness of this measure appears small, failure to insure proper air flow through the system prevents proper tune-up, degracles the comfort of the occupants, and could ultimately damage the system. Thus, cleaning the evaporator coils is ofien considered a necessary repair item.

Table A.6. Estimate of cooling energy and cost savings from central air-conditioning maintenance measures

\begin{tabular}{|c|c|c|c|c|}
\hline $\begin{array}{l}\text { Climate } \\
\text { Region }\end{array}$ & $\begin{array}{c}\text { Air Filter } \\
\text { Maintenance } \\
\text { ( } \sim 9 \% \text { savings }) \\
(\sim \$ 10 \text { cost }) \\
\text { Cooling Saving } \\
\text { kWh, } \\
\text { \$/yr } \\
\text { SIR cool }\end{array}$ & $\begin{array}{c}\text { Clean Evaporator } \\
\text { Coils } \\
(\sim 8 \% \text { savings }) \\
(\sim \$ 150 \text { cost }) \\
\text { Cooling Savings } \\
\text { kWh, } \\
\$ / y x \\
\text { SIR cool }\end{array}$ & $\begin{array}{c}\text { Correct Refrigerant } \\
\text { Charge } \\
(\sim 11.5 \% \text { savings }) \\
(\sim \$ 40 \text { cost }) \\
\text { Cooling Savings } \\
\text { kWh, } \\
\$ / y r \\
\text { SIR cool }\end{array}$ & $\begin{array}{c}\text { Total Cooling Savings } \\
\text { kWh, } \\
\$ / y r, \\
\text { SIR cool }\end{array}$ \\
\hline Humid & $\begin{array}{c}122 \mathrm{kWh} \\
\$ 10 \\
4.3\end{array}$ & $\begin{array}{c}108 \mathrm{kWh} \\
\$ 9 \\
0.3\end{array}$ & $\begin{array}{c}155 \mathrm{kWh} \\
\$ 12 \\
1.4\end{array}$ & $\begin{array}{c}385 \mathrm{kWh} \\
\$ 31 \\
0.7\end{array}$ \\
\hline Gulf & $\begin{array}{c}250 \mathrm{kWh} \\
\$ 20 \\
8.9\end{array}$ & $\begin{array}{c}222 \mathrm{kWh} \\
\$ 18 \\
0.5\end{array}$ & $\begin{array}{c}320 \mathrm{kWh} \\
\$ 26 \\
2.8\end{array}$ & $\begin{array}{c}792 \mathrm{kWh} \\
\$ 64 \\
1.4\end{array}$ \\
\hline Dry & $\begin{array}{c}144 \mathrm{kWh} \\
\$ 11 \\
5.1\end{array}$ & $\begin{array}{c}128 \mathrm{kWh} \\
\$ 10 \\
0.3\end{array}$ & $\begin{array}{c}184 \mathrm{kWh} \\
\$ 15 \\
1.6\end{array}$ & $\begin{array}{c}456 \mathrm{kWh} \\
\$ 36 \\
0.8\end{array}$ \\
\hline Central & $\begin{array}{c}144 \mathrm{kWh} \\
\$ 11 \\
5.1\end{array}$ & $\begin{array}{c}128 \mathrm{kWh} \\
\$ 10 \\
0.3\end{array}$ & $\begin{array}{c}184 \mathrm{kWh} \\
\$ 15 \\
1.6\end{array}$ & $\begin{array}{c}456 \mathrm{kWh} \\
\$ 36 \\
0.8\end{array}$ \\
\hline Pacific & $\begin{array}{c}29 \mathrm{kWh} \\
\$ 2 \\
1.0 \\
\end{array}$ & $\begin{array}{c}26 \mathrm{kWh} \\
\$ 2 \\
0.1\end{array}$ & $\begin{array}{c}37 \mathrm{kWh} \\
\$ 3 \\
0.3\end{array}$ & $\begin{array}{c}92 \mathrm{kWh} \\
\$ 7 \\
0.2\end{array}$ \\
\hline
\end{tabular}

1) Cost savings are based on electrical energy costs of $8 \dot{c} / \mathrm{kWh}$

2) Extrapolated from literature references, and EIA A/C consumption data

3) Tune-up measure lifetime estimated at 5 years

\section{References}

Burns, R. and Hough, R.E. Monitoring and Evaluation of Replacing Low-Efficiency Air Conditioners with HighEfficiency Air Conditioners in Single-Family Detached Houses in Austin. Texas, ORNL/Sub/86-SA566/V, Oak Ridge National Laboratories, Oak Ridge, TN, August, 1991.

EIA, 1993, Household Energy Consumption and Expenditures 1990, Energy Information Administration, DOE/EIA0321 (90), February 1993. 
Hammerlund, J., Proctor, J., Kast, G. and Ward, T., 1992. "Enhancing the Performance of HVAC and Distribution Systems in Residential New Construction," 1992 ACEEE Summer Study on Energy Efficiency in Buildings, Vol. 2, American Council for an Energy Efficient Economy, Washington D.C.

Henderson, H.I., 1990. "A Side by Side Field Test of Variable Speed and Constant Speed Air Conditioners," ASHRAE Transactions, Vol. 96, Pt. 1, American Society of Heating, Refrigerating and Air Conditioning Engineers, Atlanta, GA.

Hough, R, Burns, P., 1990. "Effectiveness of an Air Conditioner Replacement Program in Austin, Texas," ASHRAE Transactions, Vol. 96, Pt. 2, American Society of Heating, Refrigerating and Air Conditioning Engineers, Atlanta, GA.

Houghton, D.J., Bishop, R.C., Lovins, A.B. and Stickney, B.L., 1992. Space Cooling and Air Handling, Technology Atlas, E-Source, Inc., Boulder, CO.

Jenkins, V., 1991. “Heat Pump Study: Tricks of the Trade That Can Pump Up Efficiency," Home Energy Magazine, Vol. 8, No. 2, March/April.

Khattar, M., Ramanan, N. and Swami, M., 1985. "Fan Cycling Effects on Air Conditioner Moisture Removal Performance in Warm, Humid Climates," International Symposium on Moisture and Humidity, FSEC-PF-75-85, Florida Solar Energy Center, Cape Canaveral, FL.

Krigger, J., 1994. Residential Energv: Cost Savings and Comfort for Existing Buildings, Saturn Resource Management, Helena, MT.

Neal, L., 1992. "Air-Conditioner Efficiency in the Real World," Home Energy Magazine, Vol. 9, No. 3, May/June.

Parker, D., Fairey, P., Gueymard, C., McCluney, R., McIlvaine, J. and Stedman, T., 1992. Rebuilding for Efficiency: Improving the Energy Use of Reconstructed Residences in South Florida, FSEC-CR-562-92, Florida Solar Energy Center, Cape Canaveral, FL.

Proctor, J. and Pernick, R.K, 1992. "Getting it Right the Second Time: Measured Savings and Peak Reduction from Duct and Appliance Repairs," 1992 ACEEE Summer Studv on Energy Efficiency in Buildings, Vol. 2, American Council for an Energy Efficient Economy, Washington D.C.

Sharp, T., 1992. The North Carolina Field Test: Field Performance of the Preliminary Version of an Advanced Weatherization Audit for the Department of Energy's Weatherization Assistance Program, ORNL/CON-362, Oak Ridge National Laboratory, Oak Ridge, TN, June, 1994.

Ternes, M. P. and Levins, W. P. Oklahoma Field Test: Air Conditioning Electricity Savings from Standard Energy Conservation Measures, Radiant Barriers and High-Efficiency Window Air Conditioners, ORNL/CON-317, Oak Ridge National Laboratory, Oak Ridge, TN, August, 1992.

VTEC Laboratories, Inc. "Hydrophilic Membrane Air Conditioning," Technical Proposal to the New York State Energy Research and Development Authority, October 17, 1994.

Wynn, S., 1994. "The Most Energy-Efficient Room Air Conditioners for 1994," FSEC-GP-56-94, Florida Solar Energy Center, Cape Canaveral, FL. 


\section{DOOR REPLACEMENT}

\section{Technology Description}

Replacing existing inefficient exterior doors (such as hollow core doors) with energy efficient models (solid core wood doors, insulating metal doors, etc.) saves energy by reducing conduction losses. Replacement doors can also save energy by reducing infiltration if the condition of the existing door and frame are significantly deteriorated. Ratings for the thermal performance of residential entry doors became available in 1994 through the National Fenestration Rating Council. These unbiased ratings should standardize manufacturers' reporting of door performance and eliminate inaccurate and unreasonable claims (Nisson 1994).

Screen doors will contribute to energy savings by allowing natural ventilation of the house to displace mechanical air-conditioning. Client education should be an integral part of screen door and insect screening installation to ensure occupants utilize natural ventilation to the fullest extent possible.

\section{Performance/Field Studies}

Little information could be located on the energy benefits of exterior door replacement or storm doors. Figure A.1 provides actual R-values for some common door/lite configurations (Nisson 1994). Notice that the inclusion of a small window may reduce door R-value by approximately $10 \%$, in steel and fiberglass doors. Replacement of a door solely on the grounds of decreased conduction losses is not likely to be cost-effective as new doors may cost over $\$ 200$ (Cummings 1989). Field tests in Central Florida on slab-on-grade homes have found that windows and doors account for approximately $16 \%-20 \%$ of all air leakage (Tooley 1989). Door replacement may be justified if the door and its frame are deteriorated to the point at which they become major contributors to air-leakage and no less costly means of reducing this air-leakage is available. Other benefits of door replacement include improved home security and customer satisfaction.

Savings from installation of screen doors rely highly on occupants using the natural ventilation in place of existing airconditioning.

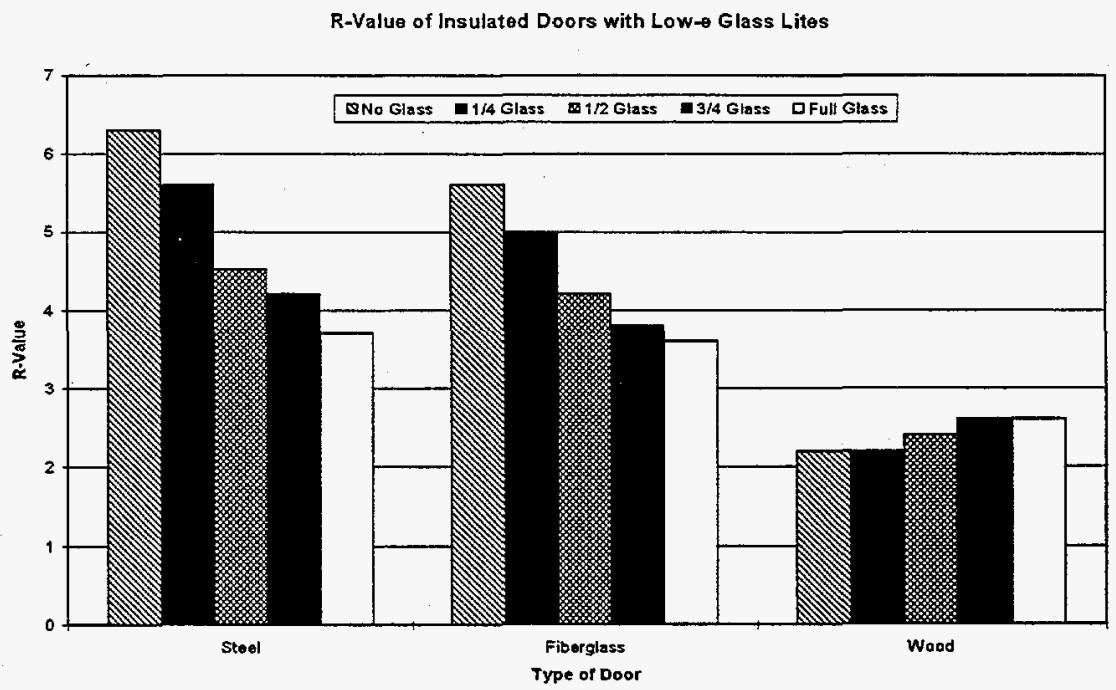

Figure A.1. R-values for common residential doors 


\section{Other Considerations}

- While it is difficult to estimate savings due to installation of screen doors, in homes without air-conditioning the additional natural ventilation provided through screen doors could greatly increase the comfort, and possibly even the health, of the occupants

\section{References}

Cummings, J.B., J. J. Tooley, and N. A. Moyer, Florida Fix Weatherization Training Manual, Florida Solar Energy Center, FSEC-GP-42-89, October 1989.

Nisson, J.D., "Door Energy Labels Readied for Market," Energy Design Update, August, 1994.

Nisson, J.D., “Overall Unit R-Value of Entry Doors," Energy Design Update, August 1994.

Tooley, J.J., and N.A. Moyer, "Air Handler Fan: A Driving Force for Air Infiltration," Home Energy Magazine, Vol. 6, No. 6, Nov/Dec 1989. 


\section{DUCT REPAIR AND INSULATION}

\section{Technology Description}

Recent research findings across the U.S. suggest that leaks and conduction problems in single-family residential distribution systems are a major source of reduced space conditioning system efficiency (Cummings et al. 1990, Modera 1993). Overall cooling energy savings from sealing efforts may range from $5-30 \%$ depending on pre-existing duct system location, leakage sites and the magnitude of initial system leakage (Cummings et al. 1991). Penetration of this option will be limited by the number of low-income homes having central systems (approximately $22 \%$ ) and by accessibility of the ducts requiring repair.

As an example of the potential for energy savings, a detailed simulation of typical Florida homes has shown that those with attic mounted duct systems use up to $30 \%$ more space cooling energy than those with ductwork mountid within other unconditioned spaces (Parker et al. 1993). Duct leakage can lead to highly variable increases in cooling and heating energy use depending upon the location and source of air leakage. The simulation also showed that conduction losses from ducts, alone, increased cooling energy use by approximately $8 \%$. Based on typical duct leakage observed in Florida homes, cooling energy use is increased by about $25 \%$.

Nearly $70 \%$ of this energy lost to leaks and conduction may be eliminated by repairs to the ductwork. Potential repair activities include duct system leakage repair using mastic, high quality tape, caulking and other appropriate materials, and the external insulation of duct systems located within unconditioned spaces. Diagnostic tests used for measuring duct leakage are: blower door subtraction, flow hood, smoke stick, pressure pan, and duct blasting. In order to effectively reduce duct problems, auditors need to be able to understand and to use the diagnostic methods and tocis to quickly determine leakage magnitude and location.

In addition to understanding duct diagnostic methods and tools, auditors must be aware of health and safety issues. Duct repair has important implications for health and safety since elimination of duct leakage can substantially lower home ventilation rates. Also, negative pressure caused by duct leakage and even duct repair, can cause spillage of combustion by-products from combustion appliances. Programs and training must take these important issues into account.

\section{Performance/Field Studies}

In Phoenix, Arizona, repairs were made to the air-distribution systems in 51 homes (Kolb 1995). The average floor area for the sample was $1,600 \mathrm{ft}^{2}$ and the average age of the sample was 13 years. The original average duct leakage of $249 \mathrm{CFM}_{50}$ was reduced by $88 \mathrm{CFM}_{50}$, or $30 \%$. With an average pre-retrofit cooling consumption of $4,890 \mathrm{kWh}$, duct repair reduced cooling consumption by $780 \mathrm{kWh}$, or $18 \%$. Based on the cost of energy in Phoenix, at $10 \mathrm{c} / \mathrm{kWh}$ annually savings were $\$ 79$. (If energy costs were $8 \mathrm{c} / \mathrm{kWh}$, savings would be $\$ 63$.) The cost of labor to perform the duct sealing work was $\$ 130$, the materials cost $\$ 10$, and Phoenix travel costs were $\$ 70$, for a combined installation cost of $\$ 210$. If repairs are done properly, and if settling and system degradation are not encountered, the lifetime of this measure should be equivalent to that remaining for the installed air-conditioner (5-10 years).

Field testing was performed on 160 Central Florida homes to identify the extent and characteristics of duct leakage. These tests were performed by the Florida Solar Energy Center (FSEC). Blower door tests found that about 13\% of total house leakage area was located in the duct system. However, because leakage sites in the duct system are under much greater operating pressure than those of the house envelope, duct leaks were found to account for $70 \%$ of building air leakage when the air handler was operating. Testing concluded that approximately $80 \%$ of Florida homes were in need of duct leakage repair. 
Fifty of the 160 homes in the FSEC study had duct leakage repair at mid-cooling season. Monitored air conditioning energy use was reduced by an average of $17 \%$ after the duct repairs were complete. The FSEC study estimated that the duct repairs could reduce winter peak electrical demand by $1.65 \mathrm{~kW}$ and summer peak demand by $1.0 \mathrm{~kW}$. In a similar study done under PG\&E's Appliance Doctor Pilot project, an $18 \%$ reduction in cooling energy consumption was achieved through duct repair and sealing efforts.

One field study has been performed on the potential of external duct insulation in reducing space conditioning energy use. It suggests that conduction losses can be reduced by $33 \%$ (Jump and Modera; 1994). However, this result and simulation studies suggest that the impact is substantially less than that from duct air leakage repair (Parker et al. 1993). A recent study by the same researchers indicates that cooling savings from installation of R-2 insulation on basement supply ducts in Atlanta would be no more than $52 \mathrm{kWh} / \mathrm{yr}$, with no savings for basement return duct insulation (Treidler 1996). The study also found a cooling consumption savings of only $16 \mathrm{kWh}$ for homes in Riverside, CA, with the installation of R-6 insulation on attic ductwork.

Effective, efficient duct leakage repair can be estimated to cost approximately $\$ 200$ per home. A cost estimate for external insulation of duct systems is only available from a study of 11 retrofitted homes in Sacramento which showed a cost averaging $\$ 448$ per house to add R-6 foil faced insulation, not including fixed or overhead expenses (Jump and Modera 1994). Duct sealing expenses averaged $\$ 350$ in the same project. Energy cost savings from these two measures will be enhanced with the additional savings provided by the heating system.

\section{Estimates of Potential Savings}

Table A.7 provides estimates for cooling energy savings based on savings reported in the literature. The term SIRcool represents the SIR strictly due to cooling energy savings, while the term SIRheat, required is the minimum SIR required from heating savings to make the overall SIR for this measure equivalent to 1.0.

Table A.7. Approximate cooling energy and cost savings, and SIR's for duct sealing and insulation

\begin{tabular}{|c|c|c|c|c|}
\hline \multirow[b]{2}{*}{ Climate Region } & \multicolumn{2}{|c|}{$\begin{array}{l}\text { Duct Sealing } \\
(-18 \% \text { savings })\end{array}$} & \multicolumn{2}{|c|}{$\begin{array}{c}\text { Duct Insulation } \\
(-2 \% \text { savings })\end{array}$} \\
\hline & $\begin{array}{c}\text { Cooling } \\
\text { Savings, } \\
\mathbf{k W h} \\
\mathbf{\$} / \mathbf{y r}\end{array}$ & $\begin{array}{l}\text { SIR cool, } \\
\text { SIR heat, } \\
\text { required }\end{array}$ & $\begin{array}{c}\text { Cooling } \\
\text { Savings, } \\
\text { kWh } \\
\text { \$/yr }\end{array}$ & $\begin{array}{l}\text { SIR cool, } \\
\text { SIR heat, } \\
\text { required }\end{array}$ \\
\hline Humid & $\begin{array}{c}243 \mathrm{kWh} \\
\$ 19\end{array}$ & $\begin{array}{l}0.77 \\
0.23\end{array}$ & $\begin{array}{c}27 \mathrm{kWh} \\
\$ 2\end{array}$ & low \\
\hline Gulf & $\begin{array}{c}500 \mathrm{kWh} \\
\$ 40\end{array}$ & $\begin{array}{c}1.63 \\
0\end{array}$ & $\begin{array}{c}55 \mathrm{kWh} \\
\$ 4\end{array}$ & low \\
\hline Dry & $\begin{array}{c}288 \mathrm{kWh} \\
\$ 23\end{array}$ & $\begin{array}{l}0.93 \\
0.07\end{array}$ & $\begin{array}{c}32 \mathrm{kWh} \\
\$ 9\end{array}$ & low \\
\hline Central & $\begin{array}{c}288 \mathrm{kWh} \\
\$ 23\end{array}$ & $\begin{array}{l}0.93 \\
0.07\end{array}$ & $\begin{array}{c}32 \mathrm{kWh} \\
\$ 9\end{array}$ & low \\
\hline Pacific & $\begin{array}{c}58 \mathrm{kWh} \\
\$ 4\end{array}$ & $\begin{array}{l}0.16 \\
0.84\end{array}$ & $\begin{array}{c}6 \mathrm{kWh} \\
\$ 1\end{array}$ & low \\
\hline
\end{tabular}

1) Cost savings are based on electrical energy costs of $8 \notin / \mathrm{kWh}$

2) Extrapolated from literature references, and EIA A/C consumption data

3) Duct sealing lifetime: 10 years and average cost: $\$ 200$; Duct insulation lifetime: 30 years, average cost $\$ 450$ 


\section{References}

Cummings, J.B., Tooley, J.J. and Dunsmore, R., 1990. "Impacts of Duct Leakage on Infiltration Rates, Space Conditioning Energy Use and Peak Electrical Demand in Florida Homes," Proceedings of the 1990 Summer Studv on Energy Efficiency in Buildings, American Council for an Energy Efficient Economy, Washington D.C.

Cummings, J.B., Tooley, J.J. and Moyer, N., 1991. Investigation of Air Distribution Svstem Leakage and its Impact in Central Florida Homes, FSEC-CR-397-91, Florida Solar Energy Center, Cape Canaveral, FL.

Jump, D.A. and Modera, M., 1994. "Energy Impacts of Attic Duct Retrofits in Sacramento Houses," Proceedings of the 1994 Summer Studv on Energy Efficiencv in Buildings, Vol. 9, American Council for an Energy Efficient Econorny, Washington D.C.

Kolb, J.O., Ternes, M.P., 1995. "Investigation of Air-Distribution System Deficiencies and Repair Benefits in Phoerix, Arizona," Proceedings of the Thermal Performance of the Exterior Envelopes of Buildings VI, ASHRAE, Atlanta, CA.

Modera, M.P., 1993. "Characterizing the Performance of Residential Air Distribution Systems," Energy and Buildings, Vol. 20, No. 1, Elsevier Sequoia, Netherlands.

Parker, D.S., Fairey, P. and Gu, L., 1993. "Simulation of the Effects of Duct Leakage and Heat Transfer on Residential Space Cooling Energy Use," Energy and Buildings, \#20, Elsevier Sequoia, Netherlands.

Proctor, J., 1991. "An Ounce of Prevention: Residential Cooling Repairs," Home Energy, Vol. 8, No. 3, May/June 1991.

Treidler, B., Modera, M., Lucas, R., Miller, J., 1996. "Impacts of Residential Duct Insulation on HVAC Energy Use and Life-Cycle Costs to Consumers," LBL-37441, Lawrence Berkeley National Laboratory, Berkeley, CA. 


\section{EVAPORATIVE COOLERS}

\section{Technology Description}

Evaporative coolers, also referred to as 'swamp coolers', produce cool air by passing hot, dry outside air through wood or synthetic pads saturated with water. The evaporation of the water cools the air, which is then forced into the house, replacing warm air, which is discharged through open windows or vents. Because the only mechanical parts are a fan and a small pump to supply the pads with water, cooling is performed very economically. Though common even in the 1930's, recent advances in materials and design, increasing costs for energy, and concern over the environment have increased interest in their use. The cost of an evaporative cooler is about $\$ 500$, and installation costs are about $\$ 500$ as well (O'Hanlon 1995). Window units will cost less. Existing coolers may be candidates for the replacement of motors with efficient, two-speed motors.

If the humidity of the outside air is already high, little cooling due to evaporation will occur. A suggested criterion for acceptable performance is an ambient air dew point of $55^{\circ} \mathrm{F}$. The systems are appropriate primarily for climates as found in the west, particularly the southwest (the dry/central climate region defined for this study). Figure A.2 illustrates these regions in which evaporative cooling is most effective. Note that regions identified as 1 and 2 in Figure A. 2 are those in which evaporative cooling is most effective.

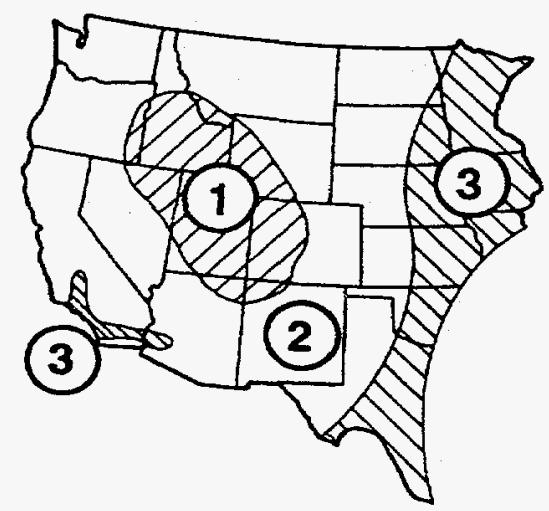

Figure A.2. Suggested regions for evaporative cooling: Regions 1 and 2 are considered effective, region 3 is considered ineffective (Krigger 1991).

While evaporative systems provide cooling in a more efficient manner, the thermodynamics of the process require a larger supply air-flow then necessary with conventional cooling. Typical evaporative coolers have SEER's of 30 40, compared to air-conditioners with SEER's from 12-15. Cooling is provided by evaporating water into a hot incoming air-stream, thus lowering the temperature of the supply air. However, in order to achieve cooling comparable to conventional systems, additional air-flow is required. For example, standard residential air-conditioners providing supply air at 1,200 to $1,500 \mathrm{cfm}$ would be fitted with evaporative systems delivering air at about 5,200 cfm (McLain 1991). Thus, while more energy efficient, evaporative systems will require the ability to open windows in order to provide adequate exhaust of the displaced inside air.

Two-stage evaporative coolers are currently being designed and tested to extend the effectiveness of the systems under extreme conditions. The most common type of two-stage system employs a pre-cooling stage to sensibly cool the air using a heat exchanger before final cooling using evaporative techniques. The cooling source for the first (pre- 
cooling) stage is an evaporatively cooled secondary air stream. One company is currently manufacturing two-stage coolers in three sizes. Two-stage systems cost about twice as much as single stage systems ( $\$ 1000$ compared to $\$ 500)$ ), with installation costs being about the same $(\$ 500)$.

\section{Performance/Field Studies}

Evaporative coolers require regular maintenance to ensure proper operation. Major cleaning should be performed every season and routine maintenance should be performed several times each season to replace pads and examine filters, the water reservoir, and pump (Krigger 1991). Pad replacement can be done by tenants, at a cost of approximately $\$ 25$ per pad (McLain 1991).

Field testing and simulation shows that evaporative coolers may reduce cooling consumption and costs by $50 \%$ to $70 \%$ compared to 'direct-expansion' air conditioners. A computer simulation predicted that a two-stage system in Phoenix would increase the number of hours an evaporative system could operate from $63 \%$ of the total number of cooling hours to $96 \%$, for a house with recommended levels of insulation and acceptable air infiltration (Huang 1992). For most California climates, the total cooling demand could also be met using the two-stage system. The greatest savings estimated by Huang (1992) for use of an evaporative cooler was $1,283 \mathrm{kWh} / \mathrm{yr}$, or about $\$ 103$ per year, in Riverside California. Although, the cooling demand could not be met with an evaporative cooler for $18 \%$ of the cooling hours. Savings may be higher in ideal climates.

Air conditioners were replaced with two-stage evaporative coolers in a field test involving six Sacramento homes. The occupants in five of the six houses relied solely on the evaporative system with satisfaction even during a two-day hot spell with temperatures of $105^{\circ} \mathrm{F}$ and $109^{\circ} \mathrm{F}$ (Hoeschele, 1994). Based on the average cooling energy consumption for the dry/central climate region (1,641 kWh per year), an annual savings of $1,172 \mathrm{kWh}(70 \%)$ was estimated for a two-stage evaporative cooler with effective EER of 35 when compared to an air-conditioner with EER of 10 . This amounts to an annual dollar savings of about $\$ 94$, assuming an electric cost of $\$ .08 / \mathrm{kWh}$.

An important issue to consider when evaluating the feasibility of evaporative cooling is the additional cost incurred by water consumption. The energy cost savings may be partially offset by the cost of water. Added daily water consumption may range from as little as 4 gallons per day to 70 gallons per day for the two-stage system in the hottest climates. This equates to a cost of $\$ 2$ to $\$ 35$ per year assuming a water cost of $\$ 4 / 1000$ gallons and 120 days of operation. Water prices tend to be the highest, though, in dry areas where the evaporative cooler is most applicable.

\section{Other Considerations}

Evaporative coolers have the potential for saving significant amounts of energy cost effectively given the correct climate and housing situation. These systems will only save energy if they are used by the occupants to displace cooling provided previously by mechanical air conditioners. To ensure a successful installation, the proper application of this measure should be addressed as well as issues concerning maintenance concerns and water supply. This measure should include a client education component to ensure occupants will be happy with these systems and thus use them, and to ensure that systems will be properly maintained.

\section{Estimates of Potential Savings}

Based on an estimated average cooling savings of $60 \%$, actual savings in the appropriate regions are estimated in Table A.8. These savings are extrapolated from the 1990 EIA cooling consumption data for low-income homes. 
Table A.8. Estimated cooling and cost savings, and SIR for single-stage evaporative cooling

\begin{tabular}{|c|c|c||}
\hline & \multicolumn{2}{|c|}{$\begin{array}{r}\text { Evaporative Cooling } \\
\text { ( 60\% savings) }\end{array}$} \\
Climate Region & $\begin{array}{r}\text { Cooling Savings, } \\
\mathrm{kWh}, \$ / \mathrm{yr}\end{array}$ & SIR cool \\
\hline Humid & not recommended & low \\
\hline Gulf & not recommended & low \\
\hline Dry & $\begin{array}{r}962 \mathrm{kWh} \\
\$ 77\end{array}$ & 0.72 \\
\hline Central & $\begin{array}{r}962 \mathrm{kWh} \\
\$ 77\end{array}$ & 0.72 \\
\hline Pacific & not recommended & low \\
\hline
\end{tabular}

1) Cost savings are based on electrical energy costs of $8 \notin / \mathrm{kWh}$

2) Savings extrapolated from literature references and EIA $A / C$ consumption data

3) Evaporative cooler lifetime: 20 years, Average cost: $\$ 1,000$ (\$500 equipment and $\$ 500$ labor), annual maintenance cost: $\$ 25$

\section{References}

Hoeschele, Marc A., "Residential Indirect/Direct Evaporative Cooler Performance in Sacramento," Proceedings of the ACEEE 1994 Summer Study on Energy Efficiency in Buildings, Vol. 9 p. 175.

Huang, Joe and Hofu Wu, "Measurements and Computer Modeling of the Energy Usage and Water Consumption of Direct and Two-Stage Evaporative Coolers," Proceedings of the ACEEE 1992 Summer Study on Energy Efficiency in Buildings, Vol. 2 p. 89.

Krigger, John T., Your Home Cooling Energy Guide, Saturn Resource Management, 1991.

McLain, H., 1991. Internal technical assessment of direct evaporative coolers, ORNL 1991.

O'Hanlon, Roger, Webb Distributors, Glendale, AZ, Personal Communication, January 1995.

Watt, J. R, "Power Cost Comparisons: Evaporative v.s. Refrigerative Cooling," ASHRAE Transactions, Vol. 94, Part 2,1988, p. 1108.

Watt, J. R, Evaporative Cooling Handbook, 2nd Ed., Chapman and Hall, 1986.

Wu, H., "Performance Monitoring of a Two-Stage Evaporative Cooler," ASHRAE Transactions, Vol. 95, Part 1, 1989, p.718. 


\section{FOUNDATION AND FLOOR INSULATION}

\section{Technology Description}

Insulating foundation spaces saves energy by reducing the heat flow between the conditioned living area and the crawlspace, basement, or slab below. In most cases, foundation insulation retrofits should be performed only after the attic and walls have been insulated (Penn 1992). Energy and cost savings will be most prevalent during the heating season, for all climates. Insulating foundations and living area floors in warm climates will produce only small, and possibly negative, cooling energy savings. The same materials and installation methods can be used in southern houses as are used in other parts of the country. Major differences between southern and northern applications involve the amount of insulation to add, and the prevalence of crawlspace and slab foundations in the south.

\section{Performance/Field Studies}

Department of Energy guidelines for new crawlspace and basement construction (also generally applicable to retrofits when no insulation is currently present) suggest installing R-19 floor insulation in homes with electric resistance heat. Exceptions include Florida and the southern most portions of Georgia, Alabama, Mississippi, Louisiana, Texas, Arizona, and California, where none is recommended. The recommendation to exclude floor insulation is extended to the majority of South Carolina, Georgia, Alabama, and Mississippi if fossil-fuel heating systems or heat pumps are present. Florida weatherization experts highly recommend R-11 floor insulation in northern Florida (Cummings 1989). Care should be taken to consider the potential for freezing pipes if the floor is insulated in homes located in cooler climates (DOE 1988).

R-19 insulation may be installed on the crawl space walls only if the crawl space is dry all year, the floor is not insulated, and all ventilation to the crawl space is blocked (DOE 1988). A moisture barrier should also be installed to prevent moisture migration into the crawlspace through walls and floors.

Unvented, unheated basements with significant sources of waste heat (from furnaces, water heaters, clothes dryers, etc.) will benefit more from wall insulation than floor insulation. Installation can be cost-effective if less expensive techniques are used which do not require wall framing (Brook 1992). Interior basement wall insulation may require a moisture barrier to be located adjacent to the foundation wall, in addition to an interior vapor barrier, to prevent moisture damage from internal and external sources. Full-height wall insulation is recommended for hollow-core block walls, in order to reduce the effects of convection between the hollow cores of the blocks (Nisson 1993).

The Building Foundation Design Handbook (Labs 1988) provides valuable insight into cooling energy savings associated with foundation insulation retrofits. Simulations were performed using a $1,500 \mathrm{ft}^{2}$ model, located in cities across the U.S., including Atlanta, Ft. Worth, Phoenix, Los Angeles and Miami. Table A.9 summarizes the results of an analysis of cooling energy savings associated with insulation retrofits to unheated basements, crawlspaces and slab-on-grade foundations. The table indicates the maximum amount of cooling energy savings possible, and the corresponding amount and configuration of insulation. In most of the cities studied, increases in cooling energy consumption were experienced. Phoenix, however, did experience some savings, with maximum savings occurring for a slab-on-grade home with R-5 insulation added to a $2 \mathrm{ft}$. foundation wall. These savings are $2.16 \mathrm{kWh} / \mathrm{ft}$, or for a $1000 \mathrm{ft}^{2}$ home with a $134 \mathrm{ft}$. perimeter, $290 \mathrm{kWh} / \mathrm{yr}$. At $8 c / \mathrm{kWh}$, this results in an annual savings of only $\$ 23$. Unfortunately, the installation cost for insulating an existing slab foundation is usually too high to be considered a cost effective retrofit. 
Table A.9. Maximum cooling energy savings, per lineal foot of foundation perimeter, and corresponding optimal insulation configuration

\begin{tabular}{|c|c|c|c|}
\hline Location & $\begin{array}{c}\text { Unconditioned Basement } \\
\text { Cooling Savings (kWh/ft), } \\
\text { Optimal Configuration }\end{array}$ & $\begin{array}{c}\text { Crawl Space } \\
\text { Cooling Savings (kWh/ft), } \\
\text { Optimal Configuration }\end{array}$ & $\begin{array}{c}\text { Slab-On-Grade } \\
\text { Cooling Savings (kWh/ft), } \\
\text { Optimal Configuration }\end{array}$ \\
\hline Atlanta, $\mathbf{G A}$ & 0, none & 0 , none & $0.66, \mathrm{R}-5 \mathrm{ext} / \mathrm{hor}$ ( $2 \mathrm{ft}$ walls) \\
\hline Ft. Worth, TX & 0, none & 0, none & $0.35, \mathrm{R}-5$ ext/hor ( $2 \mathrm{ft}$ walls) \\
\hline Phoenix, AZ & $1.41, \mathrm{R}-20 \mathrm{ext}$ & $\begin{array}{l}1.30, R-10 \text { ext/vert }(2 \mathrm{ft} \text { walls }) \\
1.70, \mathrm{R}-20 \text { ext/vert ( } 4 \mathrm{ft} \text { walls) }\end{array}$ & $\begin{array}{l}2.16, \mathrm{R}-5 \text { ext/hor ( } \mathrm{ft} \text { walls) } \\
1.47, \mathrm{R}-20 \text { ext/ver }(4 \mathrm{ft} \text { walls) }\end{array}$ \\
\hline Los Angeles, CA & 0, none & 0, none & 0 , none \\
\hline Miami, FL & 0 , none & 0, none & 0 , none \\
\hline
\end{tabular}

ext $=$ insulation located on external surface of foundation

vert $=$ insulation oriented in vertical direction

hor $=$ insulation oriented in horizontal direction

Installation costs of foundation and floor insulation will vary depending on configuration. According to Means 1996 cost data, R-11 and R-19 floor insulation cost $52 \notin / \mathrm{ft}^{2}$ and $64 \notin / \mathrm{ft}^{2}$, respectively. For a $1,000 \mathrm{ft}^{2}$ home, total floor insulation costs would be $\$ 520$ and $\$ 640$ for R-11 and R-19 levels. Similarly, Means (1996) estimates installation of $\mathrm{R}-19$ wall insulation at $45 \mathrm{\varepsilon} / \mathrm{ft}^{2}$, not including the stud framework often required. Again, for a $1,000 \mathrm{ft}^{2}$ home with $8 \mathrm{ft}$ basement walls, this would cost $\$ 483$. Weatherization work reported for homes in Minneapolis, cost $\$ 2 / \mathrm{ft}^{2}$ for interior framework, vapor barriers, and wall insulation, and $\$ 2.95 / \mathrm{ft}^{2}$ for external foundation insulation (Quaid 1989). The approximate lifetime of this measure is 25 years.

\section{Other Considerations}

- Recommendations for foundation insulation should be based on the amount of heating energy conserved, since cooling savings seems to be insignificant. Proper levels of insulation for reducing heat loss in crawlspaces and basements should be based on DOE guidelines (only if no insulation is present), sound engineering calculation procedures such as NEAT, and/or field testing. Slab insulation (typically along the slab edge) is not recommended because it is too expensive to install as a retrofit measure.

- Prior to installing insulation in crawlspaces and basements, infiltration sealing, especially at the floor/foundation wall connection, should be performed. As was discussed in the section on attic insulation, overall R-value will be diminished when air flow through the insulation exists.

- Foundation and floor insulation may increase the risk of termite infestation.

\section{Estimates of Potential Savings}

Based on the optimal insulation levels listed in Table A.9, Table A.10 lists the associated energy and cost savings, and SIR's by climate region. The term SIRcool represents the SIR strictly due to cooling energy savings, while the term SIRheat, required is the minimum SIR required from heating savings to make the overall SIR for this measure equivalent to 1.0 . 
Table A.10. Energy and cost savings, and SIR's for optimal foundation insulation levels

\begin{tabular}{|c|c|c|c|c|c|c|}
\hline \multirow[b]{2}{*}{$\begin{array}{l}\text { Climate } \\
\text { Region }\end{array}$} & \multicolumn{2}{|c|}{$\begin{array}{l}\text { Unconditioned Basement } \\
\text { Cooling Savings } \\
\text { (Optimal Insulation) }\end{array}$} & \multicolumn{2}{|c|}{$\begin{array}{c}\text { Crawl Space } \\
\text { Cooling Savings } \\
\text { (Optimal Insulation) }\end{array}$} & \multicolumn{2}{|c|}{$\begin{array}{l}\text { Slab-on-Grade Cooling Savings } \\
\text { (Optimal Insulation) }\end{array}$} \\
\hline & $\begin{array}{c}\text { Cooling } \\
\text { Savings, } \\
\text { kWh } \\
\text { \$/yr }\end{array}$ & $\begin{array}{l}\text { SIR cool, } \\
\text { SIR heat, req. }\end{array}$ & $\begin{array}{l}\text { Cooling } \\
\text { Savings, } \\
\text { kWh } \\
\text { \$/yr }\end{array}$ & $\begin{array}{l}\text { SIR cool, } \\
\text { SIR heat, req. }\end{array}$ & $\begin{array}{l}\text { Cooling } \\
\text { Savings, } \\
\mathbf{k W h} \\
\mathbf{S / y \mathbf { r }}\end{array}$ & $\begin{array}{l}\text { SIR cool, } \\
\text { SIR heat, req. }\end{array}$ \\
\hline Humid & not available & not available & not available & not available & not available & not available \\
\hline Gulf & not available & not available & not available & not available & not available & not available \\
\hline Dry & $\begin{array}{c}189 \mathrm{kWh}, \$ 15 \\
\text { (R-20 ins.) }\end{array}$ & $\begin{array}{l}0.38 \\
0.62\end{array}$ & $\begin{array}{c}200 \mathrm{kWh}, \$ 16 \\
(\mathrm{R}-10 / \mathrm{R}-20 \mathrm{avg})\end{array}$ & $\begin{array}{l}0.45 \\
0.55\end{array}$ & $\begin{array}{l}243 \mathrm{kWh}, \$ 20 \\
\text { (R-5/R-20 avg) }\end{array}$ & $\begin{array}{l}0.19 \\
0.81\end{array}$ \\
\hline Central & not available & not available & not available & not available & $\begin{array}{c}68 \mathrm{kWh}, \$ 5 \\
\text { (R-5 ins.) }\end{array}$ & $\begin{array}{l}0.05 \\
0.95\end{array}$ \\
\hline Pacific & not available & not available & not available & not available & not available & not available \\
\hline
\end{tabular}

1) Based on optimal levels for cooling savings as reported by the Building Foundation Design Guide

2) Wall/Floor R-20 cost: $\$ 640$ (w/o framing), Wall/Floor R-10 cost: $\$ 520$ (w/o framing), Slab R-5 $\$ 1,600$, all have approximate lifetimes of 25 years

3) Cost savings based on electricity costs of $8 \mathrm{e} / \mathrm{kWh}$

\section{References}

Brook, Dave, "Letters: Insulation - Caveats," Home Energy, May/June 1992, p.4.

Cummings, James B., John J. Tooley Jr., and Neil A. Moyer, Florida Fix Weatherization Training Manual, Florida Solar Energy Center, FSEC-GP-42-89, October 1989.

Greely, Kathy, John Randolph, and Bill Hill, "A Warm Wind Blows South: Virginia's Weatherization Evaluation," Home Energy, Jan/Feb 1992, p.15.

DOE, "Insulation Fact Sheet," DOE/CE-0180, January 1988.

Labs, K., Carmody, J., Sterling, R., Shen, L., Huang, Y., Parker, D., 1988. Building Foundation Design Handbook, ORNL/Sub/86-72143/1, Oak Ridge National Laboratory, Oak Ridge, TN, May 1988.

Means, 1996. Means Repair \& Remodeling Cost Data, 17th Edition, R.S. Means Co., Kingston, MA.

Nisson, J.D., Ed., "The Case Against Half-Height Foundation Wall Insulation," Energy Design Update, January 1993, p. 6.

Penn, C., 1992. "A Cozier and Cheaper Home: Home Energy's Guide to Insulation," Home Energy Magazine, January/February 1992, Vol. 9, No. 1.

Quaid, M, 1989. “To Insulate a Basement," Home Energy Magazine, Vol. 6, No. 3, May/June 1989. 


\section{HEAT PUMP WATER HEATERS AND DE-SUPERHEATERS}

\section{Technology Description}

Heat pump water heaters are dedicated heat pumps designed to heat domestic water rather than heating with resistance coils. Conventional installation uses heat from the conditioned air to heat the water, but other sources of heat may be the ambient air or waste heat from another system, such as an air-conditioner. A similar but different technology is the air conditioner/heat pump de-superheater. De-superheaters are heat exchangers installed on house air conditioners or heat pumps. They are designed to heat domestic water using the superheated refrigerant of operating air conditioners and heat pumps.

\section{Performance/Field Studies}

Heat pump water heaters have not yet penetrated the market. Reports of tests for various configured systems occur frequently (Nisson 1994, 1993). Initial estimates of the cost-effectiveness of one such system gave a simple payback of 6 to 16 years for the Pacific Northwest (Nisson 1994). A comparison of manufacturers' data indicates that heat pump water heaters may consume up to $50 \%$ less energy annually than the most efficient, equivalent-sized, conventional water heaters (Wilson 1995, Crispaire 1996). Reports of actual operation under more normal conditions indicate that savings may be $20 \%$ lower than manufacturer's claims. A Florida field study of eighty homes showed a reduction of $27 \%$ ( 8.3 to $6.1 \mathrm{kWh} /$ day) in annual water heating energy consumption from use of heat pump water heaters over conventional electric resistance units (Merrigan and Parker 1990). One vendor quote for the cost of an appropriately sized unit for a small single family home was approximately $\$ 750^{4}$ (Crispaire 1996). Professional installation costs may range from $\$ 50$ to $\$ 100$ (Means 1996).

Laboratory testing performed by Ontario Hydro found that annual energy savings up to $50 \%$ were possible when add-on units were installed with existing storage tanks (Perlman 1984). This report noted a reduction in savings when the units were used in heating-dominant homes. This occurs as the heat that is removed from the living space to heat the water increases the load on the houses' main heating system. The report also states that heat pump water heaters should have a greater impact in warmer climates because they are capable of removing some of the heat from the living space in order to heat the water. The size of this impact, however, was not determined in the report.

A study showed that heat pump water heaters are "viable and underutilized" for commercial use, but their "economics are tenuous for residential use" (George 1994). The study indicated they might be cost-effective replacing electric water heaters in residences with high hot water use in warm climates. However, the study further indicated that "conventional hot water efficiency measures - tank and pipe wraps, anti-convection valves, thermostat setbacks, and efficient shower heads and faucets - can save so much water heating energy at moderate cost, that if applied first, they will potentially render heat pump water heaters less economically desirable."

Little data exist to document the energy savings associated with de-superheaters. A Florida field showed a reduction of $11 \%$ ( 8.3 to $7.4 \mathrm{kWh} /$ day) in annual water heating energy consumption from use of desuperheater water heaters over conventional electric resistance units (Merrigan and Parker 1990). One major setback for the technology is the dependence on a heat source that is not always available. High quality waste heat is only available to the water heating system while the primary provider is operating. Thus, if an air conditioner is used

\footnotetext{
${ }^{4}$ This estimate was supplied by Crispaire and was based on a bulk purchase cost.
} 
to provide waste heat to heat water, this energy will only be available while the air-conditioner is running. A. well insulated oversized storage tank may alleviate this problem.

While the technology is available, market penetration has been relatively low. Savings are estimated to be up to $60 \%$, but will be highly dependent on the equipment accessorized and run time (Perlman 1986). The low use of de-superheaters may be due to higher costs and a lack of familiarity by field technicians. The latter may also lead to improper installation. Equipment costs, including installation, may be higher than $\$ 500-\$ 600$ (Olszewski 1986).

\section{Other Considerations}

- Consideration should be given to economics for residential applications, especially if other water heating measures are performed or major plumbing changes are needed to relocate the water heater.

- Repair costs for heat pump water heaters are typically greater than for electric resistance heaters.

- Progress in the technology should be monitored, particularly if driven by changes in appliance efficiency standards.

- The technology may evolve more quickly if and when the proposed new appliance efficiency standards take effect (Federal Register 1994; Nisson 1994). These standards require all new water heaters to have a COP greater than 1 , a specification that is inherently impossible to meet with an electric resistance water heater.

\section{Estimates of Potential Savings}

No field studies were located that could adequately predict potential savings for heat pump water heaters and de-superheaters in low-income homes. The following table estimates savings based on laboratory tests and literature claims for heat pump water heaters.

Table A.11. Estimated energy savings for replacement of conventional gas or electric water heaters with heat pump water heaters

\begin{tabular}{|c|c|c||}
\hline Climate & \multicolumn{2}{|c|}{$\begin{array}{c}\text { Energy Savings for Heat Pump Water Heaters } \\
\text { (based on original hot water equipment) } \\
\text { Energy, \$/yr, SIR }\end{array}$} \\
& $\begin{array}{c}\text { Electric } \\
40 \% \text { savings }\end{array}$ & $\begin{array}{c}\text { Gas } \\
40 \% \text { savings }\end{array}$ \\
\hline Gulf & $1,876 \mathrm{kWh}, \$ 150,2.0$ & $16 \mathrm{MBtu}, \$ 40,0.6$ \\
\hline Humid & $1,266 \mathrm{kWh}, \$ 101,1.4$ & $10.8 \mathrm{MBtu}, \$ 27,0.4$ \\
\hline Dry & $1,911 \mathrm{kWh}, \$ 153,2.0$ & $16.3 \mathrm{MBtu}, \$ 40,0.6$ \\
\hline Central & $1,911 \mathrm{kWh}, \$ 153,2.0$ & $16.3 \mathrm{MBtu}, \$ 40,0.6$ \\
\hline Pacific & $2,110 \mathrm{kWh}, \$ 169,2.3$ & $18 \mathrm{MBtu}, \$ 45,0.7$ \\
\hline
\end{tabular}

1) Based on extrapolation of literature estimates of $40 \%$ to EIA regional end-use consumption data

2) Installed cost estimated at $\$ 825$, expected lifetime is 20 years

3) Cost savings based on electricity costs of $8 € / \mathrm{kWh}$ and gas costs of $\$ 6.20 / \mathrm{MBtu}$. 


\section{References}

Crispaire, 1996. Product data and pricing from Crispaire Corp. sales associate, February, 1996.

E-Source, "Heat Pump Water Heaters: A Technology Assessment and Market Survey," E Source Inc., TU-94-9; December 1994.

Federal Register, "Notice of Proposed Rule Making," March 4, 1994.

Federal Register, 10 CFR Part 440, Vol. 58, No. 41, March 3, 1993.

George, Karen L., Ed., "E Source Study Shows Heat Pump Water Heaters Most Cost Effective in Commercial Buildings," E News, December 1994.

Means, 1996. Means Repair \& Remodeling Cost Data, 17th Edition, R.S. Means Co., Kingston, MA.

Merrigan, Tim and Danny Parker, 1990, "Electrical Use, Efficiency, and Peak Demand of Electric Resistance, Heat Pump, Desuperheaters, and Solar Hot Water Systems," 1990 ACEEE Summer Study on Energy Efficiency in Buildings, Vol. 9, p. 221, American Council for an Energy Efficient Economy, D.C.

Nisson, J. D., Ed., "Proposed Federal Rule Would Ban Electric Resistance Water Heaters," Energy Design Update, March 1994, p. 1.

Nisson, J. D., Ed., "Exhaust-Air Heat Pump Water Heaters - Good News and Bad News," Energy Design Update, November, 1994, p. 1.

Nisson, J. D., Ed., "Next Generation' (?) Heat Pump Water Heater," Energy Design Update, December 1993, p. 7.

Olszewski, M., 1984. "Economic Viability of Heat Pump De-superheaters for Supplying Domestic Hot Water," ASHRAE Transactions, Vol. 90, Part 1B, American Society of Heating, Refrigerating and Air-Conditioning Engineers, Atlanta, GA.

Perlman, M., 1984. "Heat Pump Water Heaters--A Better Water Heating Approach?," ASHRAE Transactions, Vol. 90, Part 1B, American Society of Heating, Refrigerating and Air-Conditioning Engineers, Atlanta, GA

Perlman, M., 1986. "Residential Water Heating Energy Conservation Alternatives," 1986 ACEEE Summer Studv on Energy Efficiency in Buildings, Vol. 1, American Council for an Energy Efficient Economy, Washington D.C.

Wilson, A., Morrill, J., 1995. Consumer Guide to Home Energy Savings, ACEEE, Washington, D.C. 


\section{HEAT PUMPS}

\section{Technology Description}

Heat pumps are a unique piece of equipment in that they can provide both heating and cooling for a home. They operate like a typical mechanical air-conditioner in the cooling mode. In the heating mode, they operate in reverse, pumping heat into the house from the outside. Heat pumps are typically equipped with electric resistance heaters to provide additional heating capacity. This supplemental heating is used when cold outdoor temperatures are too low for the vapor compression cycle to operate effectively.

Energy savings can be realized by replacing old heat pumps having inefficient designs with new, higherefficiency units. Energy savings can also be realized by installing high-efficiency heat pumps in houses with old air-conditioners and forced-air electric furnaces or baseboard heating. Currently available advanced air-to-air heat pumps can have seasonal energy efficiency ratios (SEER) up to 14 and heating seasonal performance factors (HSPF) up to 9 (Neal 1994). Smaller heat pumps may be installed for $\$ 2,200-\$ 3,600$ (Means 1996 ).

The actual operating efficiency of a heat pump may not always match the rated value due to differences in operating conditions and maintenance issues. The rated efficiency of a heat pump is evaluated for a single designated condition and will not precisely reflect actual behavior. Additionally, heat pumps are just as susceptible to problems concerning refrigerant charge, and distribution and equipment air-flow, as airconditioners. However, the penalties will be higher as heat pumps are used all year in meeting both heating and cooling needs. Also, if the controls for the auxiliary resistance heat are set improperly, savings will be negligible. A field study performed by PG\&E found that poor air-distribution and improper refrigerant charge increased energy consumption by $7 \%$ and $18 \%$, respectively (Jenkins 1991). For these reasons, selection based on rated efficiencies may not accurately predict results.

Considerable advances are being made in heat pump design, increasing their efficiency and use. Variablespeed heat pumps were first introduced in the U.S. in the late 1980's. Savings from their use were significant, but their high cost prevented acceptance. Recently, two-capacity air-source heat pumps and ground-source heat pumps (GSHP) have become available. Two-capacity systems, featuring either dual compressors or a single twospeed compressor, are less costly to implement than fully variable-speed compressors and their associated controls. One two-capacity air-source heat pump has a rated SEER of 16.7 (Nisson 1994).

Ground-source heat pumps are generally more efficient than air-source units of equivalent technology levels (similar compressors, heat exchangers, etc.). They are designed to extract or dump heat from or to the ground rather than outside air. They are more efficient because the ground is at a steadier, higher temperature than outside air during the winter, and at a cooler temperature during the summer. This allows the units to operate more efficiently while eliminating the use of back-up resistance heaters to supplement capacity.

Ground-source heat pumps are also more costly than air-source units due to the cost of the ground loop (about $\$ 1,000$ for horizontal loops and \$3,000 or more for vertical loops). Many electric utilities have programs to work with installers, home builders, and others to reduce the ground loop cost penalty to the consumer. A recent innovation, dual-source heat pumps, use both a ground loop and an outdoor air coil (Nisson 1994). Their ground loop costs are much lower $(\$ 150$ to $\$ 500)$ and installed costs are estimated by the manufacturer to be about the same as that for the highest efficiency air-source heat pumps available $(\$ 5,000-\$ 6,000)$. In general, the efficiency ratio of ground source heat pumps remains relatively high even at high outdoor temperatures. For instance, the dual source heat pump is reported to have and energy efficiency ratio of 15.5 at $95{ }^{\circ} \mathrm{F}$ and still over 12 at $125^{\circ} \mathrm{F}$. 


\section{Performance/Field Studies}

High cooling and heating efficiencies ( $S E E R=13.01$ and $\mathrm{HSPF}=9.05$, respectively) were measured in a field trial of an advanced air-source heat pump (ASHP) installed in Wilmington, North Carolina (Neal 1994). These units also provided essentially all of the hot water required for the family of five. The report concluded that a family in that area with an average house, a ten-year-old heat pump, and an electric water heater could expect minimum monthly electric cost savings of $\$ 50$ if the old equipment were replaced with the advanced unit. The old equipment was operating with an SEER of 3 and an HSPF of 5.6. Annual cooling energy savings were 4,955 $\mathrm{kWh}(70 \%)$ and heating savings were $2,140 \mathrm{kWh}(50 \%)$. No installed costs for the advanced system were given, however, and no cost-effectiveness tests were applied.

A study performed in the early 1980's did a side-by-side comparison of heating and cooling alternatives, for over 100 cities (Nephew 1982). These comparisons were based on simulation results for an $1,800 \mathrm{ft}^{2}$, wellinsulated house. Of specific interest, in this analysis, is the energy and cost savings associated with replacing airconditioners with electric resistance furnaces, or those with gas furnaces, with heat pumps. The efficiencies of these heat pumps were low, compared to today's technology, but savings were still obtained. Heating COP's were 2.8, while cooling EER's were 7.5.

Table A.12 lists savings for replacement of electric resistance heating units with heatpumps having a seasonal efficiency, HSPF, of 8.65. No change in the efficiency for delivery of cooling is assumed. The results reflect modified heating degree-day calculations using peak heating load and temperature data from the report by Nephew (1982). Values are averages over results obtained from heat pump installation if 39 cities within the warm climate regions. Variation of these results even within each region indicate that savings are not ensured. An audit tool, such as NEAT, would be most appropriate in the determination of feasibility of this measure.

Table A.12. Estimated annual energy savings for resistance heat replacement, cost savings, and SIR's based on present-day energy and installation costs.

\begin{tabular}{|c|c|c|c||}
\hline $\begin{array}{c}\text { Climate } \\
\text { Region }\end{array}$ & \multicolumn{3}{|c|}{ Annual Savings for Electric Resistance Heating } \\
\hline & $(\mathrm{kWh})$ & $\$$ & SIR \\
\hline Gulf & 2408 & $\$ 193$ & 0.61 \\
\hline Humid & 5238 & $\$ 419$ & 1.32 \\
\hline Dry & 4300 & $\$ 344$ & 1.09 \\
\hline Central & 5016 & $\$ 401$ & 1.27 \\
\hline Pacific & 3094 & $\$ 248$ & 0.78 \\
\hline
\end{tabular}

1) Based on simulated energy savings reported from replacement of resistance heat with heat pumps

2) Average present day installation cost is $\$ 3,500$, expected lifetime is a maximum of 15 years

3) Cost savings based on present day electricity costs of $8 \notin / \mathrm{kWh}$

Although energy savings did occur with the replacement of gas furnaces with heat pumps, the low cost of natural gas prevented this option from being cost-effective.

A study in Seattle used simulation models to track the operating performance (using HSPF's) of heat pumps over a range of temperatures (Heidell 1988). The simulation models were calibrated using actual data from 20 homes. As outdoor temperatures increased from $20^{\circ} \mathrm{F}$, performance factors increased and peaked at $32^{\circ} \mathrm{F}$. $40^{\circ} \mathrm{F}$. When outdoor temperatures rose above $45^{\circ} \mathrm{F}$, HSPF's dropped again, by nearly $12 \%$. Decreased 
performance at lower temperatures is due to the use of auxiliary resistance heat, whereas the large reduction in HSPF at higher temperatures is a direct result of heat pump cycling losses.

\section{Other Considerations}

- No significant field tests have been performed on this measure. It is highly recommended that a detailed analysis, possibly using NEAT, be performed to determine feasibility. The Electric Power Research Institute (EPRI) offers a heat pump manual which describes some calculation methods for determining the energy savings and economic benefits associated with heat pump retrofits (EPRI 1989).

\section{References}

EPRI, Heat Pump Manual, Electric Power Research Institute, EPRI EM-4110-SR, September 1989.

Heidell, J., King, M., 1988. "An Analysis of Heat Pump Performance in Seattle," Proceedings of the ACEEE 1988 Summer Studv on Energy Efficiency in Buildings, Vol. 4, p. 38.

Jenkins, V., 1991. "Heat Pump Study: Tricks of the Trade That Can Pump Up Efficiency," Home Energy, March/April 1991, Vol. 8, No. 2.

Means, 1996. Means Repair \& Remodeling Cost Data, 17th Edition, R.S. Means Co., Kingston, MA.

Neal, C. Leon., "Advanced Heat Pump Cooling and Heating Energy Savings," Proceedings of the ACEEE 1994 Summer Study on Energy Efficiency in Buildings, Vol. 3, p. 159.

Nephew, E., Abbatiello, L., 1982. Performance and Economics of Eight Alternative Systems for Residential Heating, Cooling, and Water Heating in 115 U.S. Cities, ORNL/CON-89, Oak Ridge National Laboratory, Oak Ridge, TN.

Nisson, J.D., "Dual-Compressor, Multi-capacity Heat Pumps," Energy Design Update, June, 1994.

Nisson, J.D., "Ingenious New Dual-Source Heat Pump," Energy Design Update, October, 1994. 


\section{HEAT TRAPS}

\section{Technology Description}

Heat traps installed in both the hot and cold (outlet and inlet) water pipes of a water heater will prevent standby pipe heat loss. This is done by reducing the convection from hot water rising and cold water falling, within the pipes of the water heater. Different types of traps are available or can be fabricated on site, ranging from a simple loop or elbow in the pipe to plastic lined tubes with ball and seat valves. Material costs for the devices range from $\$ 8-\$ 12$ per pair.

\section{Performance/Field Studies}

Actual energy savings from use of the devices is not well substantiated. Based on DOE's water heater test procedure, (using a mean temperature difference between ambient and tank temperatures of $77^{\circ} \mathrm{F}$ ), annual energy savings associated with locating a heat trap on the hot water outlet were $0.411 \mathrm{MBtu}$. Similarly, annual energy savings on the cold water inlet were $0.308 \mathrm{MBtu}$. For electrical water heaters, the combination of hot and cold water heat traps would provide an annual cost savings of $\$ 17$ (at $8 \phi / \mathrm{kWh}$ ). Savings with gas water heaters will be lower, at $\$ 4.50$ per year, (at $\$ 6.20 / \mathrm{MBtu}$ ). According to these estimates, heat traps should be installed on both sides of all new water heaters. As a retrofit measure, traps will probably only be cost effective when installed on electric water heaters, and not on gas systems. The estimated lifetime of this measure is equivalent to the lifetime of the water heater on which it is installed (13 year maximum).

\section{Other Considerations}

- A Florida project to build low-income housing for victims of Hurricane Andrew specifies that the hot water systems will have traps installed.

- Systems with heat traps installed on both inlet and outlet lines should also have pipe insulation located on the first few feet of both lines leaving the tank (Wilson 1995).

\section{Estimates of Potential Savings}

Table A.13. Estimated energy and cost savings, and SIR's from heat trap installation

\begin{tabular}{|c|c|c|c|c|}
\hline & \multicolumn{2}{|c|}{ Heat Trap Electrical Energy Savings } & \multicolumn{2}{|c|}{ Heat Trap Gas Energy Savings } \\
Climate & $\begin{array}{c}\text { Savings, } \\
\mathbf{k W h} \\
\text { Region }\end{array}$ & SI/ & $\begin{array}{c}\text { Savings, } \\
\text { MBtu } \\
\$ / y r\end{array}$ & SIR \\
\hline All & 211 & 5.73 & $\begin{array}{c}0.72 \\
\$ 5\end{array}$ & 0.57 \\
\hline
\end{tabular}

1) Based on reported savings

2) Average cost is $\$ 30$ ( $\$ 10$ for traps, $\$ 20$ for labor), expected lifetime is a maximum of 13 years

3) Cost savings based on electricity costs of $8 \mathrm{k} / \mathrm{kWh}$ and natural gas costs of $\$ 6.20 / \mathrm{MBtu}$ 


\section{References}

Nisson, J. D. Ned, Ed., Energy Design Update, Vol. 13, No. 4, April 1993, p. 12.

Nisson, J. D. Ned, Ed., Energy Design Update, Vol. 14, No. 10, October 1994, p. 14.

BDAC (Building Design Assistance Center) Energy Files, Florida Solar Energy Center, Vol 2 No. 2, 1994.

Meier, Alan, Ed., Home Energy, Vol. 9, No. 1, January/February 1992, p. 4.

Wilson, A., Morrill, J., 1995. Consumer Guide to Home Energy Savings, ACEEE, Washington, D.C. 


\section{WATER HEATER TANK AND PIPE INSULATION}

\section{Technology Description}

Efforts to insulate water heaters and their inlet/outlet pipes are relatively common and inexpensive energy efficiency options. Insulating bare tanks with levels ranging from R-7 to R-11 will reduce heat loss through the tank walls by $25 \%$ to $40 \%$ while saving $4 \%-9 \%$ of water heating consumption and costs (Wilson 1995). Additionally, both hot and cold water pipes should be insulated 3 to 5 feet from the water heater with pipe insulation. Most of the energy saved with these measures directly translates to a reduction in the heating load placed on the heating components within the tank. Any additional cooling energy savings are obtainable only if the tank is located within a conditioned space.

\section{Performance/Field Studies}

Energy savings will vary depending on the location of the hot water heater, and dollar savings will vary additionally based on the cost of the fuel (gas versus electric). Reported savings estimates range from 360 to $1,000 \mathrm{kWh}$ per year $(\$ 30$ to $\$ 80$ per year at $\$ .08 / \mathrm{kWh}$ ) for the tank wrap. With an installed cost between $\$ 20$ and $\$ 30$, the cost-effectiveness of the option, when applied to electric water heaters, appears well founded.

Estimates of savings for the pipe insulation alone are under $\$ 10$ per year, with one study unable to demonstrate any savings. With installation costs estimated at between $\$ 10$ and $\$ 25$, the cost-effectiveness of pipe insulation, alone, is not as well established.

The estimated lifetime of these measures is equivalent to the remaining lifetime of the water heater on which they are installed (13. year maximum).

\section{Other Considerations}

- Care must be exercised during installation on gas water heaters to observe local fire codes. It is important to keep all insulation away from the drain, the combustion air entrance at the bottom of the tank and the exhaust gas flue at the top.

- The wiring on electric heaters should always be checked before installing the insulation. Also, make sure that pressure relief valves are not disturbed by insulation.

- In some cases, newer more efficient units may already be insulated to at least R-24, and may not require additional insulation. Additionally, some manufacturers may recommend against additional insulation.

- Installation costs for pipe insulation can likely be reduced if performed at the same time as tank insulation.

\section{Estimates of Potential Savings}

Using the ELA 1990 residential energy data for hot water consumption in low-income homes, the following table estimates savings from tank wrapping, based on a $4 \%-9 \%$ reduction in consumption. According to these estimates, while energy savings are the same for both types of water heaters, cost savings are larger for electric water heaters due to the higher cost of electricity. 
Table A.14. Estimated consumption and cost savings, and SIR associated with tank insulation, for electric and gas-fired water heaters.

\begin{tabular}{|c|c|c|c|c|}
\hline \multirow[t]{2}{*}{ Climate } & \multicolumn{2}{|c|}{$\begin{array}{l}\text { Annual Savings for Electric Water Heaters } \\
\text { (kWh, S, SIR) }\end{array}$} & \multicolumn{2}{|c|}{$\begin{array}{c}\text { Annual Savings for Gas Water Heaters } \\
\text { (MBtu, S,SIR) }\end{array}$} \\
\hline & $4 \%$ reduction & $9 \%$ reduction & $4 \%$ reduction & $9 \%$ reduction \\
\hline Gulf & $187 \mathrm{kWh}, \$ 15,6$ & $422 \mathrm{kWh}, \$ 34,14$ & $0.64 \mathrm{MBtu}, \$ 4,1.9$ & $1.44 \mathrm{MBtu}, \$ 9,4.2$ \\
\hline Humid & $126 \mathrm{kWh}, \$ 10,4$ & $284 \mathrm{kWh}, \$ 23,9$ & 0.43 MBtu, $\$ 3,1.4$ & 0.97 MBtu, \$6, 2.8 \\
\hline Dry & $190 \mathrm{kWh}, \$ 15,6$ & $430 \mathrm{kWh}, \$ 34,14$ & 0.65 MBtu, \$4, 1.9 & $1.47 \mathrm{MBtu}, \$ 9,4.2$ \\
\hline Central & $190 \mathrm{kWh}, \$ 15,6$ & $430 \mathrm{kWh}, \$ 34,14$ & 0.65 MBtu, $\$ 4,1.9$ & $1.47 \mathrm{MBtu}, \$ 9,4.2$ \\
\hline Pacific & $211 \mathrm{kWh}, \$ 17,7$ & $475 \mathrm{kWh}, \$ 38,15$ & $0.72 \mathrm{MBtu}, \$ 4,1.9$ & $1.62 \mathrm{MBtu}, \$ 10,4.6$ \\
\hline
\end{tabular}

1) Based on extrapolation of reported savings to EIA regional hot water consumption data

2) Average cost is $\$ 25$, expected lifetime is a maximum of 13 years

3) Cost savings based on electricity costs of $8 \% / \mathrm{kWh}$ and natural gas costs of $\$ 6.20 / \mathrm{MBtu}$

\section{References}

Brown, Marilyn A., et al., "Impact of the Hood River Conservation Project on Electricity Use for Residential Water Heating," ORNL/CON-238, October 1987.

Cohen, Sam, "Fifty Million Retrofits Later," Home Energy, May/June 1990, p. 16.

Cowell, Stephen, et al., "Energy Fitness: Canvassing Urban Neighborhoods," Home Energy, Mar/Apr 1992, pgs. 27-33.

Cummings, James B., John J. Tooley Jr., and Neil A. Moyer, Florida Fix Weatherization Training Manual, Florida Solar Energy Center, FSEC-GP-42-89, October 1989.

Goeltz, Richard and Eric Hirst, "Residential Retrofit Measures in the Hood River Conservation Project: Recommendations, Installations, and Barriers," ORNL/CON-208, June 1986.

Greely, Kathy, John Randolph, and Bill Hill, "A Warm Wind Blows South: Virginia's Weatherization Evaluation," Home Energy, Jan/Feb 1992, p.15.

Wilson, A., Morrill, J., 1995. Consumer Guide to Home Energy Savings, ACEEE, Washington, D.C. 


\section{WATER HEATER TEMPERATURE SETBACK}

\section{Technology Description}

Lowering the temperature of a water heater saves energy by reducing tank heat loss. The need to reduce the temperature can be easily determined by an auditor through measurement of the exit temperature at the faucet closest to the water heater. Yet, there remains some uncertainty as to the minimum temperature that heaters should be set. The correct setting will be dependent on the needs and configuration of the hot water system as a whole. Thus careful consideration should be given to dishwashing, shower, and laundry requirements.

Dishwashers will have the highest temperature requirements of all of the components within the hot water loop. Manufacturers prefer that older dishwashers be supplied with hot water at a minimum temperature of $140^{\circ} \mathrm{F}$, with the sole purpose to prevent spotting on glasses (Brook 1994). However, new enzymatic detergents may reduce the problems associated with lower temperatures. Newer models that are equipped with booster heaters can also handle lower, more efficient temperatures. If the customer is indifferent to the possible spotting problems found with older units, or if a newer unit is installed, temperatures below $120^{\circ} \mathrm{F}$ would be acceptable for systems with dishwashers.

The temperature requirements for laundry and showers are generally lower than that for dishwashers. According to ASHRAE, showers and baths need water at $110^{\circ} \mathrm{F}$. Experience at Veterans Administration Hospitals has found that a maximum temperature of $110^{\circ} \mathrm{F}$ is required for laundry, and that sufficient disinfection and stain removal occur at temperatures of $72^{\circ} \mathrm{F}$ (Casebolt 1993). In this same report, Casebolt recommends that hot water temperatures be set as low as $111^{\circ} \mathrm{F}$ if (1) pipe runs are relatively short and insulated, (2) the hot water heater is equipped with a new aquastat with $\pm 2^{\circ} \mathrm{F}$ accuracy, (3) if a dish washer (if present) has a booster heater, and (4) the household does not have occupants at risk of Legionella infection, otherwise, a setting of $120^{\circ} \mathrm{F}$ is suggested.

Temperature settings should not be so low as to allow for the possibility for growth of Legionella bacteria. Middle-aged and older-occupants, particularly smokers, have an increased chance of contracting the disease when it is inhaled through an atomized water source. Additionally, persons with suppressed immune systems, such as those with cancer, kidney failure, diabetes or AIDS are also at a greater risk. Information from the CDC indicates that the bacteria will reproduce at high rates in warm, stagnant water at temperatures of $95^{\circ} \mathrm{F}-115^{\circ} \mathrm{F}(\mathrm{CDC}$ 1996). Potential growth sites include plumbing systems and hot water tanks. A recent paper describes concerns regarding bacterial growth at lower temperatures and references several studies regarding the temperature this growth occurs. A minimum setting of $135^{\circ} \mathrm{F}$ is indicated from this latter study.

If large temperature reductions are possible, gradually decreasing the temperature would allow the occupants to more comfortably adjust their lifestyles to a lower setpoint. For example, incremental temperature adjustments might be performed at the time of the initial audit, and then during the final inspection, rather than making just one large adjustment.

\section{Performance/Field Studies}

Energy savings depend on the location and insulation level of the storage tank; length, location, and insulation of pipes; the amount of hot water used; and the previous and new hot water temperature settings. According to ACEEE, each $10^{\circ} \mathrm{F}$ decrease in temperature will save 3\% - 5\% in water consumption and costs (Wilson 1995). Savings have been reported as high as $635 \mathrm{kWh}$ per year $(\$ 51$ per year at $\$ .08 / \mathrm{kWh}$ ) (Cowell 1992). Adjustment costs for this measure are negligible and the estimated lifetime is equivalent to the remaining lifetime of the water heater (13 year maximum). 


\section{Other Considerations}

- This measure should be accompanied by client education to help ensure that the setpoint is not raised back to higher values.

- When reducing temperatures to values lower than $135^{\circ} \mathrm{F}$ in homes with elderly and chronically ill occupants, the possible health effects on should be considered.

\section{Estimates of Potential Savings}

Table A.15. Estimates of savings associated with setpoint reduction of water heaters

\begin{tabular}{|c|c|c|c|c|}
\hline \multirow[t]{2}{*}{ Climate } & \multicolumn{2}{|c|}{$\begin{array}{l}\text { Annual Savings for Electric Water Heaters } \\
\qquad(\mathbf{k W h}, \mathbf{S}, \mathbf{S I R})\end{array}$} & \multicolumn{2}{|c|}{$\begin{array}{l}\text { Annual Savings for Gas Water Heaters } \\
\text { (MBtu, S, SIR) }\end{array}$} \\
\hline & $10^{\circ} \mathrm{F}$ reduction $(4 \%)$ & $20^{\circ} \mathrm{F}$ reduction $(8 \%)$ & $10^{\circ} \mathrm{F}$ reduction $(4 \%)$ & $20^{\circ} \mathrm{F}$ reduction $(8 \%)$ \\
\hline Gulf & $187 \mathrm{kWh}, \$ 15$, high & $374 \mathrm{kWh}, \$ 30$, high & $0.64 \mathrm{MBtu}, \$ 4$, high & 1.28 MBtu, \$8, high \\
\hline Humid & $126 \mathrm{kWh}, \$ 10$, high & $253 \mathrm{kWh}, \$ 20$, high & $0.43 \mathrm{MBtu}, \$ 3$, high & $0.86 \mathrm{MBtu}, \$ 5$, high \\
\hline Dry & $191 \mathrm{kWh}, \$ 15$, high & $381 \mathrm{kWh}, \$ 30$, high & $0.65 \mathrm{MBtu}, \$ 4$, high & 1.30 MBtu, \$8, high \\
\hline Central & $191 \mathrm{kWh}, \$ 15$, high & $381 \mathrm{kWh}, \$ 30$, high & $0.65 \mathrm{MBtu}, \$ 4$, high & $1.30 \mathrm{MBtu}, \$ 8$, high \\
\hline Pacific & $211 \mathrm{kWh}, \$ 17$, high & $422 \mathrm{kWh}, \$ 34$, high & $0.72 \mathrm{MBtu}, \$ 4$, high & 1.44 MBtu, \$9, high \\
\hline
\end{tabular}

1) Based on extrapolation of reported savings to EIA regional end-use consumption data

2) Average cost is minimal, expected lifetime is a maximum of 13 years

3) Cost savings based on electricity costs of $8 \notin / \mathrm{kWh}$ and natural gas costs of $\$ 6.20 \mathrm{MBtu}$

4) $\mathrm{SIR}=$ 'high' indicates minimal installation cost and immediate payback

\section{References}

Brook, D., "Water-Heater Temperature Settings," Home Energy, Vol. 11, No. 4, July/Aug 1994.

Casebolt, Cathleen, "Ready, Get Set, Heat Water!" Home Energy, Jan/Feb 1993, p. 7.

Cowell, Stephen, et al., "Energy Fitness: Canvassing Urban Neighborhoods," Home Energy, Mar/Apr 1992, pgs. 27-33.

CDC, 1996. "Legionellosis," Centers for Disease Control and National Center for Infectious Diseases web-site: (http://www.cdc.gov).

Wilson, A., Morrill, J., 1995. Consumer Guide to Home Energy Savings, ACEEE, Washington, D.C. 


\section{WATER HEATER TIMERS AND TANKLESS WATER HEATERS}

\section{Hot-Water Timers: Technology Description and Performance}

A timer can be installed on an electric hot water heater to discontinue heating during unoccupied or night hours, allowing residual heat in the tank to supply what little hot water might be needed during that time. Timers are most effective on un-insulated water heaters operating at high-temperatures without pipe insulation or heat traps. Additionally, this measure could require occupant lifestyle changes. Unhappy clients could easily dismantle the timer and eliminate its usefulness. See cautions regarding growth of Legionella bacteria discussed under "Water Heater Temperature Setback."

The Florida Weatherization Program feels this measure is "generally recommended and cost-effective." Savings are estimated as $\$ 10 /$ year while costing $\$ 30$ to install (Cummings 1989).

\section{Tankless Water Heaters: Technology Description and Performance}

Tankless water heaters are installed in line with water piping to heat water directly as it is needed. Both electric and gas models are available. Energy savings on the order of $10 \%-15 \%$ are realized as tank heat loss is eliminated (Wilson 1995). Additional energy may be saved by locating the heaters close to hot water outlets such as showers, washing machines or sinks. Energy savings may be reduced with a gas-fired heater, as the pilot light consumes an added amount of energy.

Tankless water heaters are limited by their individual capacity. More than one tankless heater may be needed, depending on the simultaneous demand for hot water. Even the largest electric tankless water heater is only capable of delivering hot water at a rate of $1.0 \mathrm{gpm}$, which is below the $2.5 \mathrm{gpm}$ flow rate of new efficient shower heads. In addition, utilities would probably discourage the additional $3 \mathrm{~kW}-5 \mathrm{~kW}$ in demand associated with operating a tankless water heater. The largest gas-fired systems can provide hot water at a rate of $3.0 \mathrm{gpm}$, which may be more appropriate for very conservative consumers. According to manufacturer's information, electric tankless heaters have retail prices of $\$ 265$, while the gas-fired units cost $\$ 1,174$ (Controlled Energy Corp. 1996).

The Department of Housing and Urban Development and the Federal Housing Authority have listed guidelines for minimum hot water capacities in single-family homes (ASHRAE 1995). Both require that tankless systems installed in single-family homes must have a minimal capacity of $3.0 \mathrm{gpm}$. This would necessitate the use of three electric tankless heaters, or one large gas heater. Thus, according to these guidelines and the small amount of savings associated with tankless heaters, their use would probably not be cost effective.

\section{Estimates of Potential Savings}

Table A.16 lists the estimated savings for water heater timers, and tankless water heaters. Theses estimates are based on extrapolation of savings discussed in the literature to EIA data (1993) on low-income hot water consumption for each warm climate region. 
Table A.16. Estimates of savings and SIR's for water heater timers and tankless water heaters

\begin{tabular}{|c|c|c|c|c|c|}
\hline \multirow[t]{2}{*}{ Climate } & \multirow{2}{*}{$\begin{array}{l}\text { Annual Savings for } \\
\text { Electric Water } \\
\text { Heater Timers } \\
\text { (kWh, \$, SIR) } \\
10 \text { \$/yr (all climates) }\end{array}$} & \multicolumn{4}{|c|}{$\begin{array}{l}\text { Annual Savings for Tankless Water Heaters } \\
\text { (kWh or MBtu, S, SIR) }\end{array}$} \\
\hline & & $\begin{array}{l}\text { Electric } \\
10 \% \text { savings }\end{array}$ & $\begin{array}{c}\text { Electric } \\
15 \% \text { savings }\end{array}$ & $\begin{array}{l}\text { Gas } \\
10 \% \text { savings }\end{array}$ & $\begin{array}{l}\text { Gas } \\
15 \% \text { savings }\end{array}$ \\
\hline Gulf & $125 \mathrm{kWh}, \$ 10,3.4$ & $\begin{array}{l}469 \mathrm{kWh}, \\
\$ 37,0.47\end{array}$ & $\begin{array}{l}703 \mathrm{kWh} \\
\$ 56,0.71\end{array}$ & $\begin{array}{l}1.6 \mathrm{MBtu} \\
\$ 10,0.1\end{array}$ & $\begin{array}{l}2.4 \mathrm{MBtu} \\
\$ 10,0.15\end{array}$ \\
\hline Humid & $125 \mathrm{kWh}, \$ 10,3.4$ & $\begin{array}{l}316 \mathrm{kWh} \\
\$ 25,0.32\end{array}$ & $\begin{array}{l}475 \mathrm{kWh} \\
\$ 38,0.48\end{array}$ & $\begin{array}{l}1.08 \mathrm{MBtu} \\
\$ 7,0.07\end{array}$ & $\begin{array}{l}1.62 \mathrm{MBtu} \\
\$ 10,0.10\end{array}$ \\
\hline Dry & $125 \mathrm{kWh}, \$ 10,3.4$ & $\begin{array}{l}477 \mathrm{kWh}, \\
\$ 38,0.48\end{array}$ & $\begin{array}{l}716 \mathrm{kWh} \\
\$ 57,0.73\end{array}$ & $\begin{array}{l}1.63 \mathrm{MBtu} \\
\$ 10,0.1\end{array}$ & $\begin{array}{l}2.4 \mathrm{MBtu} \\
\$ 15,0.15\end{array}$ \\
\hline Central & $125 \mathrm{kWh}, \$ 10,3.4$ & $\begin{array}{l}477 \mathrm{kWh} \\
\$ 38,0.48\end{array}$ & $\begin{array}{l}716 \mathrm{kWh} \\
\$ 57,0.73\end{array}$ & $\begin{array}{l}1.63 \mathrm{MBtu} \\
\$ 10,0.1\end{array}$ & $\begin{array}{l}2.4 \mathrm{MBtu} \\
\$ 15,0.15\end{array}$ \\
\hline Pacific & $125 \mathrm{kWh}, \$ 10,3.4$ & $\begin{array}{l}527 \mathrm{kWh} \\
\$ 42,0.53\end{array}$ & $\begin{array}{c}791 \mathrm{kWh} \\
\$ 63,0.8\end{array}$ & $\begin{array}{l}1.8 \mathrm{MBtu}, \\
\$ 11,0.11\end{array}$ & $\begin{array}{l}2.7 \mathrm{MBtu}, \\
\$ 17,0.17\end{array}$ \\
\hline
\end{tabular}

1) Timer savings based on reported savings

2) Tankless water heater savings based on extrapolation of reported savings to EIA regional end-use consumption data

3) Timer cost: $\$ 30$, Electric tanks (3) cost: $\$ 795$, Gas tank (1) cost: $\$ 1,174$. Lifetime is a maximum of 13 years

4) Cost Savings based on electricity costs of $8 \mathrm{k} / \mathrm{kWh}$ and natural gas costs of $\$ 6.20 / \mathrm{MBtu}$

\section{References}

ASHRAE, 1995. HVAC Applications, ASHRAE, Atlanta, GA.

Cummings, James B., John J. Tooley Jr., and Neil A. Moyer, Florida Fix Weatherization Training Manual, Florida Solar Energy Center, FSEC-GP-42-89, October 1989.

Controlled Energy Corporation, 1996. Pricing information obtained through phone conversation, 1-800-6423111.

EIA, 1993, Household Energy Consumption and Expenditures 1990, Energy Information Administration, DOE/ELA-0321 (90), February 1993.

Meier, Alan, Ed., Home Energy, "Letters: Tankless," Mar/Apr 1990, pg. 3-4.

Wilson, A., Morrill, J., 1995. Consumer Guide to Home Energy Savings, ACEEE, Washington, D.C. 


\section{INFILTRATION REDUCTION}

\section{Technology Description}

Reducing the amount of unconditioned air which leaks into a house reduces the heating and cooling loads which must be met by the conditioning systems in providing a comfortable environment. Ambient air is forced into a house by pressure differences across the building envelope created by wind, indoor-outdoor temperature differences, and pressures from forced air-conditioning systems. Application of caulking and weatherstripping around doors and windows was an early approach to reducing infiltration. More current approaches use blowerdoor-directed techniques to identify the leaks, track progress, and determine when further work would no longer be cost effective. Guidelines for determining the cost-effectiveness of work are based on the potential to reduce heating energy consumption and do not generally take into consideration the possible effects on cooling.

Studies in Florida and Washington State (Nisson 1993) have shown significant links between infiltration and duct leakage in forced air distribution systems. Forced air distribution systems can increase air leakage rates substantially. Special consideration should be given to air leakage from the attic space to ductwork since the attic air temperature during the cooling season is substantially higher than the outdoor air. Air sealing in humid climates can also reduce the indoor relative humidity, reducing latent air-conditioning loads and the likelihood for mold and mildew growth, while increasing occupant comfort.

Building materials other than caulks and weatherstripping may provide reduction in air-leakage. Research findings at the National Association of Home Builders (NAHB) Research Center and the National Research Council Canada (NRC) indicate that use of ordinary paint rather than polyethylene vapor retarders provide adequate resistance to moisture diffusion through walls and ceilings (Nisson 1994). Other tests at NAHB have shown that use of a self-adhering tape specifically made for patching seams and cracks in buildings works as well in new construction as wrapping the entire house (Nisson 1993). The potential application of this as a retrofit measure exists. Strategies for using high-density blown cellulose wall insulation also take into account potential air leakage sites (Greely 1992 and Lutz 1992).

Guidelines dictating minimum infiltration rates based on traditional theories generally indicate higher minimums in southern climates $\left(1,500-2,500 \mathrm{cfm}_{50}\right)$ than in northern climates (Tsongas 1993). The basis of these guidelines (e.g. ASHRAE Standard 62, 1989) are primarily control of odors and four specific pollutants (Nisson 1993). Current thought is shifting away from minimum rates and focusing on occupancy comfort, controlling the source of pollutants, and cleaning and filtering indoor air to insure indoor air quality (Nisson 1994 and 1993). This reflects the consensus opinion of workshop attendees at the 1994 Affordable Comfort Conference where emphasis was placed on control of pollutants, not minimum air exchange rates, to insure indoor air quality. However, "natural air infiltration alone cannot be relied upon to consistently maintain recommended levels of ventilation, even in leaky houses" (Nisson 1994).

\section{Performance/Field Studies}

Infiltration reduction work has essentially concentrated on the reduction of winter heating loads. Unfortunately, no real documentation exists to quantify the potential for cooling energy (sensible and latent) or peak load savings associated with this measure. Field tests might be appropriate, however the little documentation that is available suggests that sensible cooling energy savings are negligible.

Air-sealing techniques emphasized under Virginia's Weatherization Program used a blower door to locate major leaks in the attic, basement/crawlspace, bypasses, ducts, and registers. Sealing efforts have been more effective when concentrated away from the neutral pressure plane, where stack-effect infiltration is greater. The 
program recommended, for the Virginia climate, setting a maximum cost for sealing work at $\$ 32$ per $100 \mathrm{cfm}_{50}$ of desired reduction in leakage. For a $30 \%$ reduction in infiltration, $\$ 300$ was spent on each home for air-sealing. No results for cooling energy savings were reported.

Similarly, a study performed in Oklahoma on low-income homes examined the effect of air-sealing measures installed under the Weatherization Program (Ternes 1992). Typical air-sealing efforts, including caulking and weatherstripping, were improved through the use of a blower door to locate major leaks. Resulting air leakage was reduced by an average of $1,200 \mathrm{cfm}_{50}$ (or $35 \%$ ), at an average cost of $\$ 340$. The study concluded that airsealing was justified by space-heating energy savings alone and that no savings in cooling energy consumption were detected.

Florida weatherization experts recognize that many of the factors (large indoor-outdoor temperature differences, strong winds, and multi-story buildings) contributing to the adverse effects of air infiltration are less prevalent in their climate. For this reason, air infiltration reduction is "strongly recommended" in northern Florida, "recommended" in central Florida, but "not highly recommended" in southern Florida, though large leaks should always be repaired (Cummings 1989).

\section{Other Considerations}

- Weatherization experts agree that air sealing should not be performed, or at least put off, until corrective action can be taken when problems with indoor air-quality are present. Such problems include homes with unvented space heaters, existing carbon monoxide levels above $50 \mathrm{ppm}$, questionable exhausting of combustion appliances, or the possibility of a cracked heat exchanger.

- A primary goal for weatherization work should be to ensure that all infiltration reduction efforts, if performed, use blower-door directed procedures. Additional issues that should be considered include limitations on tightening levels of houses, how to include cooling and humidity into the guidelines, and how to address health and safety concerns found during the work.

- Minimum infiltration work may be warranted in the hottest climates such as the southern most parts of Florida and Texas.

\section{Estimates of Potential Savings}

According to initial literature reviews, sensible cooling savings associated with this measure tend to be negligible. No savings will be estimated for the warm climate regions until additional information, from literature or field testing, is obtained.

\section{References}

Cummings, James B., John J. Tooley Jr., and Neil A. Moyer, Florida Fix Weatherization Training Manual, Florida Solar Energy Center, FSEC-GP-42-89, October 1989.

Greely, Kathy, John Randolph, and Bill Hill, "A Warm Wind Blows South: Virginia's Weatherization Evaluation," Home Energy, Jan/Feb 1992, p.15.

Lutz, Karina, "Air Sealing Before and After," Home Energy, Jan/Feb 1992, p.18. 
Nisson, J.D., Energy Design Update, "Workshop on 'Too Tight' Houses Declares 'No Such Thing'," and "Housetape," April 1994, pg. 1.

Nisson, J.D., Energy Design Update, "Ordinary Paint as Replacement for Poly Vapor Retarder," May 1994, pg. 5.

Nisson, J.D., Energy Design Update, "The Effect of Duct Leakage on House Air Infiltration Rate," October 1993, pg. 7.

Nisson, J.D., Energy Design Update, "The Advantage of Housewrap on a Totally Airtight Wall," October 1993, pg. 5.

Nisson, J.D., Energy Design Update, "The Ventilation Rate Myth," September 1993, pg. 10.

Ternes, M. P. and Levins, W. P. Oklahoma Field Test: Air Conditioning Electricity Savings from Standard Energy Conservation Measures, Radiant Barriers and High-Efficiency Window Air Conditioners, ORNL/CON317, Oak Ridge National Laboratory, Oak Ridge, TN, August, 1992

Tsongas, George, "Building Tightness Guidelines: When Is A House Too Tight," Home Energy, March/April 1993,pg. 18. 


\section{LIGHTING}

\section{Technology Description}

Replacing indoor incandescent lights with compact fluorescents (CFL's) is a easy way to save energy in the home. Old incandescent bulbs with wattages from $40 \mathrm{~W}$ to $100 \mathrm{~W}$ may be replaced by fluorescent lamps that cut energy consumption by $20 \%-75 \%$. This is due to the higher lighting efficiency, or efficacy, associated with compact fluorescents. While less expensive to operate, compact fluorescents cost up to 20 times more than incandescents, however their life expectancy is 10 times greater. As a result, the replacement of a $75-\mathrm{W}$ incandescent lamp with a 20-W CFL will pay for itself in 3 years, if used for 4 hours per day (Wilson 1995). Cost-effectiveness is highest when replacement occurs in fixtures that are most often used; such as those on porches, in family rooms, and in kitchens.

There are several options available when selecting the appropriate combination of CFL's for a home (Byrne 1994). Unlike incandescent lamps, CFL's require ballasts to operate. Two configurations are available: integral and modular. An integral CFL is a one-piece, self-ballasted lamp, which relies on an electronic ballast for power control. Conversely, the larger modular CFL allows the lamp to be removed from a magnetic ballast, for replacement. Since magnetic ballasts last 50,000 hours, replacement of the fluorescent tube every 10,000 hours is more economically attractive (Wilson 1995). Some disadvantages of the modular CFL include: size, humming from the magnetic ballast, and delayed start-up (Leslie 1993). Both types have choices of twin-, triple-, or quadtube lamps. The triple- and quad-tube lamps are smaller and tend to be more compatible with existing fixtures.

In order to ensure maximum and effective replacement, and tenant satisfaction, several issues must be considered. A rule-of-thumb for determining equivalent CFL wattage is to divide the wattage of the existing incandescent lamp by 3 , and select the CFL with the closest rating (Leslie 1993). For instance, a 75-W lamp may be replaced by a $26-\mathrm{W}$ or a $20-\mathrm{W}$ CFL, and a $60-\mathrm{W}$ lamp, with a $15-\mathrm{W}$ CFL. The CFL ratings include lamp and ballast power. In situations were existing fixtures won't easily allow for installation of CFL's, adaptive hardware such as replacement harps, harp adaptors and socket extenders may be used to aid in the transition. Rated performance may be slightly reduced when the CFL's are installed in a base-down position. Finally, most CFL's are not dimmable and for the purpose of safety, should not be installed in dimmer circuits.

Average costs for ballasted CFL's are $\$ 10$ - \$20 and replacement lamps for modular CFL's cost \$6-\$14 (Leslie 1993). Bulb lifetimes can be up to seven years, while ballasts may last 28 years (Cowell 1992).

\section{Performance/Field Studies}

Conservation work performed for the Spectrum Neighborhood Program in Boston, found $80 \%$ of reported energy savings to be a direct result of CFL retrofits (Cowell 1992) ${ }^{5}$. Using adaptive hardware, installers were able to replace an average of 6 bulbs per home, in low- and mid-income houses. The majority of these included 18-W and 15-W integral CFL's, with minimum daily burn-times of $2 \mathrm{hrs.} \mathrm{Resulting} \mathrm{annual} \mathrm{energy} \mathrm{savings} \mathrm{was}$ $321 \mathrm{kWh}$.

A study performed for a New England utility found similar results in low-income homes (Granda 1992). The Energy Fitness Program targeted low-income customers in Massachusetts, Rhode Island, and New Hampshire for CFL replacements in both 1990 and 1991. The study reflects a sample taken from a population of over

\footnotetext{
${ }^{5}$ The Spectrum Neighborhood Program addressed measures covering hot water, lighting, cleaning of refrigerator coils, and airconditioning filters.
} 
37,000 homes. An average of 5.3 lamps were replaced with CFL's, at no charge to the customer. Average savings of $295 \mathrm{kWh}$ and $143 \mathrm{kWh}$ where reported for 1990 and 1991. A problem often encountered was removal of the CFL's due to insufficient lighting level. In fact, the average removal rate for the CFL's installed was over $30 \%$. The results of this study suggest that CFL retrofits should be matched to pre-retrofit incandescent illumination levels and that tenant dissatisfaction will quickly result in removal.

\section{Other Considerations}

- Cheap electronic ballasts may cause interference with television controls, timers, or other appliances.

- Care should be taken to select CFL's with a high CRI, or color rendition index. This is a measure of the ability of the lamp to illuminate colors in an accurate manner. Incandescent lamps are rated at $95+$, while the better CFL's are rated at 82 . Additionally, color temperatures of $2,700 \mathrm{~K}$ to $3,000 \mathrm{~K}$ will best replicate the color provided with incandescent lamps (Leslie 1993).

\section{Estimates of Potential Savings}

Based on average savings reported from the Boston and New England programs, Table A.17 summarizes savings estimated for the replacement of 5 and 6 incandescent bulbs with CFL's.

Table A.17. Estimate of energy and cost savings from replacement of incandescent lamps with CFL's

\begin{tabular}{|c|c|c|}
\hline $\begin{array}{l}\text { Climate } \\
\text { Region }\end{array}$ & $\begin{array}{c}\text { Savings with replacement } \\
\text { of } 5 \text { bulbs per home with } \\
\text { CFL's } \\
\text { (kWh, } \$ / y r, \text { SIR }) \\
(1990,1991 \text { average) }\end{array}$ & $\begin{array}{c}\text { Savings with replacement } \\
\text { of } 6 \text { bulbs per home with } \\
\text { CFL's } \\
(\mathrm{kWh}, \$ / \mathrm{yr}, \mathrm{SIR})\end{array}$ \\
\hline All & $\begin{array}{l}219 \mathrm{kWh}, \\
\$ 18,1.2\end{array}$ & $\begin{array}{c}321 \mathrm{kWh}, \\
\$ 26,1.4\end{array}$ \\
\hline
\end{tabular}

1) Savings based on field tests

2) Average lamp cost: $\$ 18$, lifetime is 7 years

\section{References}

3) Cost savings based on electricity costs of $8 \notin / \mathrm{kWh}$

Byme, J., "Energy-Efficient Lighting for the Home," Home Energy, Nov/Dec 1994.

Cowell, Stephen, et al., "Energy Fitness: Canvassing Urban Neighborhoods," Home Energy, Mar/Apr 1992, pgs. 27-33.

Granda, C., 1992. "A Statistically Based Impact Evaluation of a Direct Install Compact Fluorescent Distribution Program," Proceedings of the ACEEE 1992 Summer Studv on Energy Efficiency in Buildings, Vol. 4.

Leslie, R., Conway, K., 1993. The Lighting Pattern Book for Homes, Lighting Research Center, Rensselaer Polytechnic Institute, Troy New York.

Wilson, A., Morrill, J., 1995. Consumer Guide to Home Energy Savings, ACEEE, Washington, D.C. 


\section{LOW-FLOW SHOWERHEADS AND FAUCET AERATORS}

\section{Technology Description}

As part of the 1992 National Energy Policy Act, all showerheads and faucets sold in the U.S. after January 1994, must have low-flow ( $<2.5 \mathrm{gpm}$ ) capacities. Low-flow showerheads and aerators installed on kitchen and bathroom faucets save energy by reducing the flow rate of water (and hence use of hot water) while maintaining rinsing action. Low-flow showerheads usually limit flow to less than $2.5 \mathrm{gpm}$, a rate nearly half of that found in existing showerheads ( 3.5 to $5 \mathrm{gpm}$ ). A study performed by the state of Oregon found 413 models of low-ilow showerheads from 24 different manufacturers. Costs for low-flow showerheads range from $\$ 2.00$ to $\$ 60.00$ depending on the features.

\section{Performance/Field Studies}

Lowest cost flow reduction (2-3 gpm) can be achieved by placing a small restricting disk into the existing shower head. New showerheads can be purchased which offer constricted flow. Aerating showerheads attempt to simulate the sensation of conventional showerheads by reducing the droplet size by mixing air with the water. Unfortunately, aeration imposes a 'cooling-tower effect' which lowers the temperature of the water by the time it reaches the user. One study has indicated a $7^{\circ} \mathrm{F}$ difference, while another found no essential temperature difference between aerating and non-aerating showerheads. However, as a result, many users may increase the temperature by $1^{\circ} \mathrm{F}$ to $10^{\circ} \mathrm{F}$ (Meier 1990). This, along with increased shower-times corresponding to lower flows, are two take-back effects that may reduce the effectiveness of this measure.

Savings estimates for low-flow showerheads vary from 230 to $450 \mathrm{kWh}$ per year $(\$ 18-\$ 36$ per year at $\$ .08 / \mathrm{kWh}$ ). A method of incorporating regional differences in the savings estimate is available in Hickman's "Clearing Up: An Efficient Approach for Estimating Showerhead Savings" (Hickman 1994). In Oregon, savings from these measures are expected to be about $25 \%$ of the space heating consumption savings resulting from improvements in that state's residential energy code. Low-flow showerheads are specified in plans for construction of low-income homes to be built for victims of Hurricane Andrew in Florida (BDAC 1994).

Savings from installing aerators on the kitchen and bathroom faucets have been estimated at about $150 \mathrm{kWh}$ per year $(\$ 12$ per year at $\$ .08 / \mathrm{kWh})$ at a cost of $\$ 2.00$. Actual savings could vary widely depending on habits of the occupants.

\section{Estimates of Potential Savings}

Table A.18. Estimates of savings and SIR's for water heater timers and tankless water heaters

\begin{tabular}{|c|c|c|c|c|}
\hline \multirow{2}{*}{$\begin{array}{l}\text { Climate } \\
\text { Region }\end{array}$} & \multicolumn{2}{|c|}{$\begin{array}{c}\text { Average Faucet Aerator } \\
\text { Savings }\end{array}$} & \multicolumn{2}{|c|}{$\begin{array}{c}\text { Average Low-Flow Showerhead } \\
\text { Savings }\end{array}$} \\
\hline & $\begin{array}{c}\text { Electric } \\
\text { kWh, \$, SIR }\end{array}$ & $\begin{array}{c}\text { Gas } \\
\text { MBtu, \$, SIR }\end{array}$ & $\begin{array}{c}\text { Electric } \\
\text { kWh, S, SIR }\end{array}$ & $\begin{array}{c}\text { Gas } \\
\text { MBtu, \$, SIR }\end{array}$ \\
\hline All & $\begin{array}{l}150 \mathrm{kWh}, \\
\$ 12,60\end{array}$ & $\begin{array}{c}0.5 \mathrm{MBtu} \\
\$ 3,17\end{array}$ & $\begin{array}{c}340 \mathrm{kWh}, \$ 27, \\
8.8\end{array}$ & $\begin{array}{l}1.2 \mathrm{MBtu}, \\
\$ 7,2.6\end{array}$ \\
\hline
\end{tabular}

1) Estimates based on reported savings

2) Faucet aerator cost: $\$ 2$, low-flow showerhead average cost: $\$ 31$; lifetime is a maximum of 13 years

3) Cost savings based on electricity costs of $8 \mathfrak{e} / \mathrm{kWh}$ and natural gas costs of $\$ 6.20 \mathrm{MBtu}$ 


\section{References}

BDAC (Building Design Assistance Center) Energy Files, Florida Solar Energy Center, Vol 2 No. 2, 1994.

Carver, Phil and David Siefarth, "Showerhead Codes -- with Teeth," Home Energy, Mar/Apr 1992, pgs. 34-37.

Hickman, Curtis, et al., "Clearing Up: An Efficient Approach for Estimating Showerhead Savings," Transactions of ACEEE, 1994, Vol. 8 , p. 8.89.

Meier, Alan, Ed., "Letters: Quality Showerhead Manufacturer Takes Exception," Home Energy, Jul/Aug 1990, pg. 3-4.

Meier, Alan, "Low-Flow Showerheads, Family Strife, and Cold Feet," Home Energy, Jan/Feb 1990, p. 37.

Nisson, J. D. Ned, Ed., "On Doubts about Low-Flow Showerheads," Energy Design Update, Vol. 13, No. 9, September 1993, p. 5.

Nisson, J.D., "After the Hurricane: Energy-Retrofitting South Florida," Energy Design Update, April, 1993. 


\section{RADIANT BARRIER SYSTEMS}

\section{Technology Description}

Attic radiant barriers provide summer heat relief by reducing the loads in attic spaces. An attic radiant barrier system (RBS) consists of a layer of aluminum foil placed in the attic air space to block radiant heat transfer between the roof surface and the attic insulation below. Ceiling heat gain may be reduced by $17 \%-42 \%$, depending on pre-existing insulation levels and ventilation rates (Al-Asmar 1996). According to DOE (1991), this reduction in cooling load translates into a potential reduction in cooling energy consumption of $2 \%-10 \%$. Experimental data indicates that cooling savings will be larger when used with lower amounts of attic insulation and/or when ductwork is located within the attic. Little information is available on the impacts of RBS on heating loads, however the percentage reduction in winter heat losses appear to be lower than those for summer heat gains (DOE 1991).

The success of radiant barriers in reducing cooling loads is highly dependent on proper selection and installation. High performance radiant barriers will have low emissivity ratings, at $0.03-0.06$, and high reflectivity ratings, at $95 \%-97 \%$. Installation in existing homes may be either on the attic floor, or on the bottom of the roof rafters. Roof mounting substantially reduces the potential for dust collection and extends the service life of the measure (Fairey et al. 1988; Levins et al. 1990). Proper installation of RBS is covered in design notes from Florida Solar Energy Center (Fairey 1984) and from ASTM standard C-1158.

Radiant barriers can be applied in most roofing systems. However, attic geometry may limit the number of homes that can use the technology. The requirements for an effective air space for adequate radiant barrier performance and the need for ready access will limit the ability to use RBS in homes with very low slope roofs (poor access) and for those with cathedral ceilings. In homes with feasible, but very poor attic access, additional labor costs may make such applications economically unattractive. Perhaps two thirds of existing homes in the south could feasibly have an RBS installed.

An installed radiant barrier can be assumed to cost approximately $\$ 0.15-\$ 0.35 /$ square of roof area. This cost was estimated through contacts with several vendors in Florida and Texas (Parker et al. 1991; Medina et al. 1994). The range of the costs is also in general agreement with the costs encountered in a recent residential retrofit program in Oklahoma (Ternes and Levins 1992). Since space heating energy savings are likely to be lower, the economics of RBS will be greatest in climates with extreme cooling needs, or in homes with high summer utility bills.

\section{Performance/Field Studies}

Radiant barriers are a well documented means to reduce the rate of heat transfer through the ceiling of residential buildings (Fairey et al. 1988). For instance, field measurement of the retrofit of ceiling insulation from R-11 to R-30 in a test home in Tennessee showed a 16\% drop in the measured cooling energy use (Levins and Karnitz 1987). Addition of RBS in these tests also showed a level of cooling energy savings similar to that of the R-30 insulation. However, these measurements were made in a home with the air distribution system in the crawlspace. Larger savings from the RBS would be expected were the ducts located in the attic, which is common in homes with slab on grade construction (Parker et al. 1991; Medina 1994). Generally, previous research in the Southeast has shown that roof mounted radiant barriers can reduce ceiling heat flux by $30-50 \%$ with annual cooling electricity savings of $7-10 \%$ (Fairey et al. 1988, 1989; Wilkes 1991; Ober 1991; Ashley et al. 1994). Reduction of peak cooling loads is generally higher. 
Although isolated field studies abound, the performance of radiant barriers as an effective weatherization measure remains largely undemonstrated. For instance, a series of retrofits in homes in Oklahoma showed no measurable savings (Ternes and Levins 1992). The reasons for this result are largely unexplained, but may have to do with changing use habits for the room air conditioners, the small sample size of the RBS weatherization group against the large variances, and low pre-retrofit estimates of potential savings. It is likely that savings for RBS retrofits would be much more robust when used in centrally air conditioned households. Careful testing of two unoccupied side-by-side centrally air conditioned homes in Gainesville Florida showed an $8 \%$ reduction in peak day air-conditioning with R-19 ceiling insulation (Fairey et al. 1988).

The Department of Energy offers additional technical assistance on radiant barriers through the Radiant Barrier Fact Sheet (DOE 1991). This report provides details on installation, material costs, and lifetime expected total energy savings. Table A.19 lists these savings for homes located in cities throughout the warm climate region. These data are based on energy simulations and are presented here for a $965 \mathrm{ft}^{2}$ home (the average floor area for low-income homes in the region). The results of the simulations indicate that cost effectiveness is greater in attics with lower levels of insulation.

Table A.19. Present value of lifetime total energy savings associated with installation of roof rafter radiant barriers in homes with existing levels of insulation. (DOE 1991)

\begin{tabular}{|c|c|c|c|c|c|c|}
\hline Location & ducts in attic & $\begin{array}{l}\text { Present V } \\
-11 \\
\text { ducts not in attic }\end{array}$ & e of Lifetime & $\begin{array}{l}\text { ergy Savings (in } \\
19 \\
\text { ducts not in attic }\end{array}$ & $5 \mathrm{ft}^{2}$ home) & $\begin{array}{l}30 \\
\text { ducts not in attic }\end{array}$ \\
\hline Albuquerque & $\$ 261$ & $\$ 232$ & $\$ 145$ & $\$ 116$ & $\$ 96$ & $\$ 77$ \\
\hline Atlanta & $\$ 241$ & $\$ 203$ & $\$ 125$ & $\$ 96$ & $\$ 77$ & $\$ 58$ \\
\hline El Toro & $\$ 212$ & $\$ 183$ & $\$ 116$ & $\$ 96$ & $\$ 77$ & $\$ 58$ \\
\hline Houston & $\$ 270$ & $\$ 222$ & $\$ 145$ & $\$ 116$ & $\$ 96$ & $\$ 68$ \\
\hline Knoxville & $\$ 241$ & $\$ 212$ & $\$ 125$ & $\$ 106$ & $\$ 87$ & $\$ 68$ \\
\hline Los Angeles & $\$ 116$ & $\$ 106$ & $\$ 68$ & $\$ 58$ & $\$ 48$ & $\$ 39$ \\
\hline Memphis & $\$ 261$ & $\$ 222$ & $\$ 135$ & $\$ 106$ & $\$ 87$ & $\$ 68$ \\
\hline Miami & $\$ 347$ & $\$ 270$ & $\$ 193$ & $\$ 145$ & $\$ 125$ & $\$ 87$ \\
\hline Orlando & $\$ 309$ & $\$ 251$ & $\$ 164$ & $\$ 125$ & $\$ 116$ & $\$ 77$ \\
\hline Phoenix & $\$ 415$ & $\$ 347$ & $\$ 222$ & $\$ 164$ & $\$ 135$ & $\$ 96$ \\
\hline Raleigh & $\$ 232$ & $\$ 193$ & $\$ 116$ & $\$ 96$ & $\$ 77$ & $\$ 58$ \\
\hline Riverside & $\$ 357$ & $\$ 261$ & $\$ 164$ & $\$ 125$ & $\$ 96$ & $\$ 68$ \\
\hline Sacramento & $\$ 251$ & $\$ 222$ & $\$ 135$ & $\$ 116$ & $\$ 96$ & $\$ 68$ \\
\hline Waco & $\$ 299$ & $\$ 251$ & $\$ 164$ & $\$ 125$ & $\$ 106$ & $\$ 77$ \\
\hline
\end{tabular}

1) Cost savings are based on electrical energy costs of $0.0786 \$ / \mathrm{kWh}$, heating costs of $\$ 5.27 / \mathrm{MBtu}$, and a lifetime of 25 years

2) Model assumes cooling set point of $78^{\circ} \mathrm{F}$, heating set point of $70^{\circ} \mathrm{F}$, furnace efficiency of $65 \%$, A/C COP of 2.34 


\section{Other Considerations}

- Additional details regarding the use of radiant barriers and comparison with the benefit of installing additional insulation may be obtained from the "Radiant Barrier Attic Fact Sheet" DOE/CE-0335P, (DOE 1991).

- Radiant barriers should receive more emphasis in the future as a weatherization measure in extreme cooling climates such as those in the southern parts of Florida, Texas, Louisiana, Alabama, Mississippi and Georgia. Economics are most attractive in households using considerable air-conditioning and in centrally cooled homes. High cooling use households may be identified through analysis of existing billing data.

- In most of the moderately warm climates, attic insulation may be a more cost effective alternative.

\section{Estimates of Potential Savings}

Table A.20 provides estimates of SIR's associated with installation of radiant barriers in attics with preexisting levels of insulation. SIR's are calculated using the net present values given in the Radiant Barrier Fact sheet (listed in Table A.19), along with current installation costs for roof mounted barriers.

Table A.20. SIR's for total energy savings associated with installation of roof rafter radiant barriers in homes with existing levels of attic insulation

\begin{tabular}{||c|c|c|c|c|c|c||}
\hline \multirow{2}{*}{ Location } & \multicolumn{5}{|c|}{ SIR's from Total Energy Savings (in 965 $\mathrm{ft}^{2}$ home) } \\
& \multicolumn{2}{|c|}{ w/ R-11 attic insulation } & \multicolumn{2}{|c|}{ w/ R-19 attic insulation } & \multicolumn{2}{c|}{ w/ R-30 attic insulation } \\
& ducts in attic & ducts not in attic & ducts in attic & ducts not in attic & ducts in attic & ducts not in attic \\
\hline Gulf & 0.86 & 0.69 & 0.46 & 0.36 & 0.31 & 0.21 \\
\hline Humid & 0.68 & 0.58 & 0.35 & 0.28 & 0.23 & 0.17 \\
\hline Dry & 0.82 & 0.71 & 0.45 & 0.35 & 0.29 & 0.22 \\
\hline Central & 0.83 & 0.70 & 0.45 & 0.35 & 0.29 & 0.21 \\
\hline Pacific & 0.63 & 0.51 & 0.32 & 0.26 & 0.21 & 0.15 \\
\hline
\end{tabular}

1) Cost savings are based on electrical energy costs of $0.0786 \$ / \mathrm{kWh}$, heating costs of $\$ 5.27 / \mathrm{MBtu}$, and a lifetime of 25 years

2) Model assumes cooling set point of $78^{\circ} \mathrm{F}$, heating set point of $70^{\circ} \mathrm{F}$, furnace efficiency of $65 \%, \mathrm{~A} / \mathrm{C} \mathrm{COP}$ of 2.34

3) Installation cost of $32.5 \% / \mathrm{ft}^{2}$

\section{References}

Al-Asmar, H.R., Jones, B.W., Matteson, D.K., 1996. “Experimental Evaluation of Attic Radiant Barriers," ASHRAE Transactions, Vol. 102, Part 1, American Society of Heating, Refrigerating and Air-Conditioning Engineers, Atlanta, GA.

Ashley, R., Garcia, O., Medina, M.A. and Turner, W.D., 1994. "The Effect of Radiant Barrier Technology on Summer Attic Heat Load in South Texas," Proceedings of the Ninth Symposium on Improving Building Systems in Hot and Humid Climates, Arlington, TX.

Department of Energy (DOE), "Radiant Barrier Attic Fact Sheet," DOE/CE-0335P, June 1991. 
Fairey, P. Swami, M. and Beal, D., 1988. Radiant Barrier Systems Technology: Task 3 Report, Florida Solar Energy Center, FSEC-CR-211-88, Cape Canaveral, FL.

Fairey, P., 1984. "Designing and Installing Radiant Barrier Systems," Florida Solar Energy Center, FSEC-DN-784, Cape Canaveral, FL.

Levins, W. P. and Karnitz, M. A. Cooling Energy Measurements of Single-Family Houses with Attics Containing Radiant Barriers in Combination with R-11 and R-30 Insulation, ORNL/CON-226, Oak Ridge National Laboratories, Oak Ridge, TN.

Levins, W. P. and Karnitz, M. A. and Hall, J.A., 1990. Cooling Season Energy Measurements of Dust and Ventilation Effects on Radiant Barriers, ORNL/CON-271, Oak Ridge National Laboratories, Oak Ridge, TN.

Medina, M.A., Turner, W.D. and O'Neal, D.L., 1994. "Economic Evaluation of Insulation/Radiant Barrier Systems for the State of Texas," Proceedings of the Ninth Symposium on Improving Building Systems in Hot and Humid Climates, Arlington, TX.

Ober, D.G. Attic Insulation Performance: Full Scale Tests of Conventional Insulation and Radiant Barriers, Mineral Insulation Manufacturer's Association, Final Report, Denver, CO, July, 1990.

Parker, D.S., Fairey, P. and Gu, L., 1993. "Simulation of the Effects of Duct Leakage and Heat Transfer on Residential Space Cooling Energy Use," Energy and Buildings, \#20, Elsevier Sequoia, Netherlands

Ternes, M.P. and Levins, W.P. 1992. The Oklahoma Field Test: Air-Conditioning Electricity Savings from Standard Energy Conservation Measures, Radiant Barriers and High Efficiency Air-Conditioners, ORNL/CON317, Oak Ridge National Laboratories, Oak Ridge, TN.

Wilkes, K.E. 1991. Analysis of Annual Thermal and Moisture Performance of Radiant Barrier Systems, ORNL/CON-319, Oak Ridge National Laboratories, Oak Ridge, TN. 


\section{REFLECTIVE ROOFING AND WALL FINISHES}

\section{Technology Description}

Reflective roofing and wall materials consist of roofing and/or wall finishes that are reflective in the solar spectrum. They have the potential to significantly reduce building cooling loads. Typically these materials are white in order to yield the highest overall solar reflectance. As a weatherization measure, reflective roofing would consist of white reflective paints for metal roofs and other reflective coatings, either elastomeric, ceramic or cementitious for other roofing types. Reflective wall systems can be achieved through the use of conventional white latex paints.

Reflective roofing should be applicable to a number of roofing types. Most readily applicable would be existing homes with metal or tile roofs which can easily be painted white at a fairly low cost. Gravel roofs can be inexpensively coated with a conventional white cementitious slurry. Use of reflective coating for manufactured homes is also common practice. For other roofing types, aesthetic concerns are likely to limit potential applications. Roofing systems offering the poorest chance of successful application are also the most numerous: asphalt shingle roofs.

Although reflective building surfaces have been used in hot climates since ancient times, adaptation to modern buildings to reduce mechanical cooling is a relatively recent development (Anderson et al., 1991; Bansal, 1992). Even though a number of products are available which have a high solar reflectance, innovations may focus on materials that are resistant to reflectance degradation. Materials research may develop colored materials with spectrally-selective properties that possess a high reflectance in the near infrared portion of the spectrum.

\section{Performance/ Field Studies}

\section{Florida Solar Energy Center Studies (FSEC)}

Reflective roofing materials have been demonstrated to be an effective means to reduce cooling loads in residential buildings. Experiments in Florida have examined the impact of reflective roof coatings on air conditioning energy use in a series of tests on occupied homes (Parker et al., 1995). The experiments were conducted on nine residential buildings from 1991 to 1994 using a before and after test protocol where the roofs were whitened at mid-summer. Measured air conditioning electrical savings in the buildings during similar pre and post weather periods averaged $19 \%$ with average utility peak coincident peak savings of $22 \%$. Cooling energy reductions were dependent on the level of ceiling insulation initially present, with averages for homes with R- 0, R-11, and R-19/25 attic insulation of $34 \%, 21 \%$, and $8 \%$, respectively. Other factors affecting savings were roof solar reflectance, air duct system location, and air conditioner sizing.

Recent research results indicate that reflective roofing may also significantly reduce cooling energy use in manufacture homes. Testing of a reflective coating added to a manufactured home with $\mathrm{R}-11$ ceiling insulation in the summer of 1995 showed a $22 \%$ reduction in air conditioning consumption.

\section{Lawrence Berkeley Laboratory Study}

The reflectivity of roofs surfaced with either an acrylic elastomeric coating, a polymer coating with an acrylic base, or a cementitious coating, were measured over a period of several years (Bretz et al. 1993). For homes with R-11 attic insulation located in California, first year cooling energy savings ranged from $40 \%$ to $69 \%$. Second year savings were reduced approximately $20 \%$ due to dirt accumulation. Further reduction in reflectivity is small. Washing of the roof surfaces returned the reflectivity to $90-100 \%$ of the estimated original value, but the benefit 
was short term since dirt accumulation can occur during the first few months. Other factors found to affect the reflectivity degradation include the roofing system geometry and smoothness, roof slope, and ambient relative humidities.

\section{Oak Ridge National Laboratory Study}

In tests performed at the Oak Ridge National Laboratory, designed primarily to examine the effects of reflectivity on the temperature of commercial low-sloped roofs, a reduction of $26 \%$ in reflectivity was measured over a 3.5 year period. Use of the Laboratory's Roof Thermal Research Facility allowed monitoring of the roof's thermal performance under actual climate conditions over an extended period of time. It was found that "for this East Tennessee location with an R-2 roof section, the ratio of the cooling-load savings to heating-load penalty was approximately 2.1 to I" (Byerley 1994). This ratio would likely be higher for a residential sloped roof, particularly above a ventilated attic. The study suggested that the building owner consider washing the roof each spring.

\section{Other Considerations}

Although field studies yielding good results have been performed in Florida and California, the performance of reflective surfaces as an effective weatherization measure remains undemonstrated. The use of reflective roof coating has become common practice, however, with manufactured homes in the southeast as well as homes with gravel or tiles roofs. Some coating systems will readily increase the life of a roofing system, aiding the project economics.

Savings associated with whitening of wall surfaces have not been studied in any empirical investigation in the U.S. Simulation analysis, however, indicates that the savings will be less than half that from changing roof reflectance (Parker et al., 1992). However, this limitation is partly offset by the fact that the finish on the vertical walls does not appear to weather as rapidly as roof surfaces.

\section{Estimates of Savings Potential}

The table below provides estimates of the cost effectiveness for application of reflective roof coatings to reduce cooling energy consumption. The estimates assume a $40 \%$ reduction in cooling energy for an uninsulated attic and a $10 \%$ for one insulated, an $\$ 0.08 / \mathrm{kWh}$ electric rate, and annual cooling energies as prescribed in the Warm Climate Situation Analysis (Situation Analysis 1995). The cost for implementing the measure varies widely. Painting with a reflective white finish may cost as little as $\$ 0.20$ per square foot whereas reflective coating systems will often cost five times as much. For the analysis below, a $\$ 0.40$ per square foot cost for a $1000 \mathrm{ft}^{2}$ roof has been assumed. The life of the coating is assumed to be 7 years, in light of the long term degradation of the reflectivity. 
Table A.21. Energy and cost savings, and SIR's for application of reflective roof coating

\begin{tabular}{||c|c|c|c|c|}
\hline \hline \multirow{2}{*}{$\begin{array}{c}\text { Climate } \\
\text { Region }\end{array}$} & $\begin{array}{c}\text { Uninsulated Attic } \\
\begin{array}{c}\text { Cooling } \\
\text { Savings, } \\
\text { kWh } \\
\text { \$/yr }\end{array}\end{array}$ & SIR cool & $\begin{array}{c}\text { Insulated Attic } \\
\text { Cooling } \\
\text { Savings, } \\
\mathbf{k W h} \\
\mathbf{S / y r}\end{array}$ & SIR cool \\
\hline Humid & $539 \mathrm{kWh}, \$ 43$ & 0.65 & $135 \mathrm{kWh}, \$ 11$ & 0.16 \\
\hline Gulf & $1113 \mathrm{kWh}, \$ 89$ & 1.34 & $278 \mathrm{kWh}, \$ 22$ & 0.33 \\
\hline $\begin{array}{c}\text { Dry/ } \\
\text { Central }\end{array}$ & $644 \mathrm{kWh}, \$ 52$ & 0.77 & $161 \mathrm{kWh}, \$ 13$ & 0.19 \\
\hline Pacific & $117 \mathrm{kWh}, \$ 9$ & 0.14 & $29 \mathrm{kWh}, \$ 2.34$ & 0.04 \\
\hline
\end{tabular}

Gross estimates for cost-effectiveness of reflective wall coatings can be taken as half those indicated in the table above.

\section{References}

Anderson, R.W., Yarbrough, D.W., Graves, R.S. and Wendt, R.L. "Preliminary Assessment of Radiation Control Coatings for Buildings," Insulation Materials: Testing and Applications, 2nd Volume, ASTM STP 1116, RS. Graves and D.C. Wysocki, Eds., American Society for Testing and Materials, Philadelphia, 1991.

Bansal, N.K, Garg, S.N. and Kothari, S., 1992. "Effect of Exterior Surface Color on the Thermal Performance of Buildings," Building and Environment, Permagon Press, Vol. 27, No. 1, p. 31-37, Great Britain.

Bretz, S. and Akbari, H., 1993. Durability of High Albedo Coatings, LBL-34974, Lawrence Berkeley Laboratory, Berkeley, CA.

Byerley, A.R and Christian, J.E., 1994. "The Long Term Performance of Radiation Control Coatings," Proceedings of the 1994 Summer Study on Energy Efficiency in Buildings, Vol. 5., p. 59, American Council for an Energy Efficient Economy, Washington D.C.

Parker, D., Fairey, P., Gueymard, C., McCluney, R., Mcllvaine, J. and Stedman, T., 1992. Rebuilding for Efficiency: Improving the Energy Use of Reconstructed Residences in South Florida, FSEC-CR-562-92, Florida Solar Energy Center, Cape Canaveral, FL.

Parker, D.S., Barkaszi, S.F., Chandra, S, and Beal, D.J., 1995. "Measured Energy Savings from Reflective Roofing Systems in Florida: Field and Laboratory Research Results," Proceedings from Thermal Performance of the Exterior Envelopes of Buildings VI, U. S. DOE, ORNL, ASHRAE, BETEC, Clearwater, FL.

Situation Analysis, 1995, “U.S. DOE Warm Climate Initiative: Situation Analysis,” DRAFT, February 1995. 


\section{REFRIGERATOR REPLACEMENT AND TUNE-UP}

\section{Technology Description}

Replacing existing refrigerators with higher efficiency models can save energy and reduce electricity demand. Today, refrigerators consume just over half of the energy $(\sim 700 \mathrm{kWh} / \mathrm{yr})$ consumed by their predecessors $(\sim 1,300$ $\mathrm{kWh} / \mathrm{yr}) 15$ years ago (George 1994). According to the EIA residential consumption data (1993), the average annual energy consumption by refrigerators located in low-income homes is $1,400 \mathrm{kWh}$, indicating the broad existence of older units. The most efficient refrigerators available now on the market consume only $500 \mathrm{kWh} / \mathrm{yr}$. These improvements in efficiency over the years have been attributed to increased insulation, tighter seals, larger coil surface areas, and improvements in compressors. The most simplistic models are most often the most efficient since energy penalties always accompany additional features. For example, side-by-side models will boost energy consumption by 7-13\% and automatic ice-makers will increase consumption by $14-20 \%$ (RMI 1996). Proper selection, including simplicity of design, should increase the resulting energy savings associated with refrigerator replacement.

Proper refrigerator maintenance, primarily through cleaning the coils and replacing leaky door seals, offers a limited potential to save energy. A dirty coil may reduce the overall efficiency by $3 \%$ per month (Cowell 1992). Experts recommend cleaning coils every 6 months (Krigger 1994), but are unable to show significant savings. Leaky door seals may be replaced, however if the leaks are a result of age, consideration should be given to a complete refrigerator replacement.

\section{Performance/Field Studies}

An examination of average energy consumption for refrigerators indicates that newer refrigerators will use $25 \%$ to $50 \%$ less energy ( $700 \mathrm{kWh} /$ year compared to $950-1400 \mathrm{kWh} /$ year) than those purchased 5 to 15 years ago, saving anywhere from $\$ 20$ to $\$ 60$ per year in electricity assuming $\$ .0825 / \mathrm{kWh}$ (George 1994). Twice this savings is predicted for units purchased 10 to 20 years ago (Meier 1993). Certain high efficiency models demonstrate even lower energy consumption, $500 \mathrm{kWh} /$ year for a standard size unit $\left(20 \mathrm{ft}^{3}\right)$, resulting in a cost savings ranging from $\$ 40$ to $\$ 75$. Savings of $1,300 \mathrm{kWh} /$ year, or $60 \%$, were demonstrated in a field trial in 27 homes (Meier 1993), and a three-year payback for refrigerator replacement was estimated for the Florida Weatherization Program (Cummings 1989). These latter two results are much greater than the other referenced estimates and appear to be overly optimistic.

Energy efficient refrigerators may be more economically attractive when used to replace older units at the end of their lifetime. The average cost of replacement units is $\$ 500$, with a lifetime of 15 years.

Field tests on maintenance-related efforts are sparse. Two trials attempting to show energy savings associated with this option were inconclusive, and a third estimated a 3\% savings (Meier 1993 and Cowell 1992). Based on the estimate of a $3 \%$ increase in monthly consumption associated with dirty coils, average annual savings resulting from regular cleaning would be $36 \mathrm{kWh}$ (Cowell 1992). Florida Solar Energy Center (FSEC) estimates tune-up costs at $\$ 20-\$ 50$ (Cummings 1989). Further data would be required to accurately evaluate the impact of maintenance tune-ups on refrigerator energy consumption.

\section{Other Considerations}

- Refrigerator replacement programs, sponsored mainly by electric utilities, are ongoing in Florida, Michigan, and California. These utility programs benefit from both the energy savings achieved from replacement units as well as associated demand reductions. 
- Programs which implement refrigerator replacement must consider the issues of disposal or recycling of the old units. Chlorofluorocarbons (CFCs) used as refrigerants must be recovered and some locations prohibit disposal of large appliances in landfills.

\section{Estimates of Potential Savings}

According to the EIA (1993) data on low-income refrigerator energy consumption, an average savings of $54 \%$ for replacement refrigerators is possible. This savings may be achieved by replacing old inefficient units with new units that consume only $700 \mathrm{kWh} /$ year. Table A.22 highlights these savings, along with estimated savings for tune-ups, for the warm climate regions.

Table A.22. Estimated consumption and cost savings, and SIR associated with refrigerator replacement and tune-up.

\begin{tabular}{|c|c|c|}
\hline Climate & $\begin{array}{c}\text { Energy Savings for } \\
\text { Refrigerator Tune-Up* } \\
\text { (3\% savings) } \\
\text { (kWh, S/yr, SIR) }\end{array}$ & $\begin{array}{l}\text { Energy Savings for } \\
\text { Replacement of } \\
\text { Refrigerators ** } \\
\text { (kWh, \$/yr, SIR) }\end{array}$ \\
\hline Gulf & $\begin{array}{l}59 \mathrm{kWh} \\
\$ 5,0.27\end{array}$ & $\begin{array}{l}1,264 \mathrm{kWh} \\
\$ 101,2.27\end{array}$ \\
\hline Humid & $\begin{array}{l}45 \mathrm{kWh}, \\
\$ 4,0.21\end{array}$ & $\begin{array}{l}795 \mathrm{kWh}, \\
\$ 64,1.45\end{array}$ \\
\hline Dry & $\begin{array}{l}51 \mathrm{kWh} \\
\$ 4,0.21\end{array}$ & $\begin{array}{c}1,000 \mathrm{kWh}, \\
\$ 80,1.81\end{array}$ \\
\hline Central & $\begin{array}{l}51 \mathrm{kWh}, \\
\$ 4,0.21\end{array}$ & $\begin{array}{c}1,000 \mathrm{kWh}, \\
\$ 80,1.81\end{array}$ \\
\hline Pacific & $\begin{array}{l}32 \mathrm{kWh} \\
\$ 3,0.16\end{array}$ & $\begin{array}{l}355 \mathrm{kWh}, \\
\$ 28,0.63\end{array}$ \\
\hline
\end{tabular}

* Savings of $3 \%$ based on literature estimates

** Savings based on a $700 \mathrm{kWh} / \mathrm{yr}$ consumption level of refrigerators presently on the market

1) Using EIA regional end-use consumption data to estimate savings

2) Average replacement cost is $\$ 500$, with a lifetime of 15 years, average tune-up cost is $\$ 35$, with a maximum lifetime every 2 years.

3) Cost savings based on electricity costs of $8 \mathrm{c} / \mathrm{kWh}$

\section{References}

Cowell, Stephen, et al., "Energy Fitness: Canvassing Urban Neighborhoods," Home Energy, Mar/Apr 1992, pgs. 27-33.

Cummings, James B., John J. Tooley Jr., and Neil A. Moyer, Florida Fix Weatherization Training Manual, Florida Solar Energy Center, FSEC-GP-42-89, October 1989.

EIA, 1993, Household Energy Consumption and Expenditures 1990, Energy Information Administration, DOE/EIA-0321 (90), February 1993.

George, Karen L., Ed., "Agreement Reached on Refrigerator Standards," E News, December 1994.

Krigger, J., 1994. Residential Energy: Cost Savings and Comfort for Existing Buildings, Saturn Resource 
Management, Helena, MT.

Meier, Alan, "Is That Old Refrigerator Worth Saving," Home Energy, Jan/Feb 1993, p. 16 - 38.

RMI, 1996. "Home Energy Brief: Refrigerators \& Freezers," Rocky Mountain Institute web site: (http://www.solstice.crest.org/efficiency/rmi). 


\section{REPLACEMENT WASHERS, DRYERS, AND DRYER VENTS}

\section{Replacement Washers}

Horizontal-axis clothes washers are expected to appear in the U.S. marketplace in 1996. They are reported to use 30-60\% less water and 50-70\% less energy than conventional models (RMI 1996 and George 1994). Savings result from reduced electricity consumption by pumps, motors and hot-water heating. Such units will probably command a premium of about $\$ 200$ over conventional washers. Some manufacturers presently have horizontal-axis units on the market, however, these units are based on European models that are not totally suitable for the U.S. market (George 1994 and Sabin 1994).

\section{Replacement Dryers}

Manufacturers are now producing and testing prototypes of microwave clothes dryers that are expected to be $10 \%-15 \%$ more efficient than conventional dryers, while also decreasing drying time. As the technology is still in a research phase, no cost or cost-effectiveness studies of this option have been performed to date (Nisson 1993 and 1994).

\section{Dryer Vents}

In warm climate regions, conventional clothes dryers must be properly vented to ensure that the warm air is exhausted outside and not to the inside of the house or crawlspace. Improper venting can increase cooling energy consumption with the introduction of additional latent and sensible heat into the house. Additionally, the potential for moisture damage and occupant discomfort are increased when warm, moist air is permitted to enter the living environment. An outside dryer vent may be installed for \$15-\$20 (RMI 1996). Existing vents should also be checked to ensure that proper sealing occurs when the dryer is not in use.

\section{Estimates of Potential Savings}

Table A.23 summarizes the limited data available on washer and dryer measures. Additional research and/or field testing is required to more accurately determine savings potential for homes in the weatherization program.

Table A.23. Estimate of energy and cost savings from replacement of washers, dryers, and dryer vents

\begin{tabular}{||c|c|c|c||}
\hline $\begin{array}{c}\text { Climate } \\
\text { Region }\end{array}$ & $\begin{array}{c}\text { Replacement Washers } \\
\text { Replacement Energy } \\
\text { Savings, Cost }\end{array}$ & $\begin{array}{c}\text { Replacement Dryers } \\
\text { Replacement Energy } \\
\text { Savings, Cost }\end{array}$ & $\begin{array}{c}\text { Dryer Vents } \\
\text { Installed Energy } \\
\text { Savings, Cost }\end{array}$ \\
\hline All & $\begin{array}{c}50 \%-70 \%, \\
\text { \$200 abe conventional } \\
\text { washers }\end{array}$ & $\begin{array}{c}10 \%-15 \%, \\
\text { not available }\end{array}$ & $\begin{array}{c}\text { not available, } \\
\$ 15-\$ 20\end{array}$ \\
\hline
\end{tabular}

1) Savings based on literature claims 


\section{References}

Benenson, Peter, et al., "Household Appliance Replacement Program - Impact and Tradeoffs," Proceedings of the ACEEE 1994 Summer Studv on Energy Efficiencv in Buildings, Vol. 8, p. 1.

George, Karen L., Ed., "H-Axis Washer Shows 73\% Energy Savings in Field Trial," ENews, December 1994.

Nisson, J.D., Ed., "Microwave Clothes Dryers - Still Coming," Energy Design Update, May, 1993.

Nisson, J.D., Ed., "Microwave Dryer Wins Popular Science Grand Award," Energy Design Update, November, 1994.

RMI, 1996. "Home Energy Brief: Refrigerators \& Freezers," Rocky Mountain Institute web site: (http://www.solstice.crest.org/efficiency/rmi).

Sabin, Bob, "H-Axis Issue Splits Laundry Vendors," Appliance Manufacturer, 1994. 


\section{SHADING}

\section{Technology Description}

Proper shading of homes, particularly windows, is an effective means of reducing energy consumption and increasing thermal comfort in cooling climates. Most of the various shading methods balance the benefit of reducing solar loads during the cooling season with decreased visibility, a loss in beneficial solar heating in the heating season, and possibly an increase in the electricity use for internal lighting.

Several shading strategies are available and selection should be done on an individual basis. Table A.24 shows the amount of solar heat gain blocked through the use of various shading devices. Efforts to reduce cooling energy consumption using shading are normally most effective when concentrated on the east and west windows of a home. Due to the elevation of the sun, south facing windows "allow the greatest and potentially most beneficial solar heat gain during the heating season, while allowing relatively little of the solar heat gain that contributes to cooling requirements during the cooling season" (Warner 1990). Moveable shading devices respond better to the dynamics of the weather by adjusting shading to meet the thermal needs of the house (Lechner 1991). Occupants, however, must be willing to remove or adjust these in order to achieve full benefits. Building characteristics and orientation, and occupant preference and participation are strong influences on performance.

Table A.24. Shading potentials for various shading devices (Krigger 1991).

\begin{tabular}{|c|c|}
\hline Shading Device & $\begin{array}{c}\text { Percent } \\
\text { Reduction in } \\
\text { Solar Heat Gain }\end{array}$ \\
\hline Solar Screen - indoors & $20 \%-30 \%$ \\
\hline Colored Venetian Blinds & $25 \%-40 \%$ \\
\hline Draperies (light colored) & $40 \%-55 \%$ \\
\hline Opaque Rolling Shade (dark) & $45 \%-50 \%$ \\
\hline White Venetian Blind & $45 \%-50 \%$ \\
\hline Window Films & $40 \%-75 \%$ \\
\hline Light-Transmitting Rolling Shade & $60 \%-70 \%$ \\
\hline Solar Screen (outdoors) & $65 \%-75 \%$ \\
\hline Opaque Rolling Shade (white) & $75 \%-80 \%$ \\
\hline Aluminum Louvered Sun Screen & $80 \%-85 \%$ \\
\hline Awnings & $50 \%-90 \%$ \\
\hline
\end{tabular}

Although interior shades, blinds and drapes can provide effective shading if they have reflective or light surfaces facing the window, it is normally a more effective strategy to prevent the sun light from ever reaching the window. Awnings are popular in hot climates and effective if sized and shaped properly for the orientation and size of the window. However, at costs as high as $\$ 125-\$ 160$ a piece, they are normally more expensive than alternative means of shading (Means 1996). Various types of shutters may be less expensive (\$60-\$90), depending on their construction, but they may also be less effective, requiring occupants to open and close them, 
or restricting visibility. Some types of external shading devices can be constructed by weatherization crews, further reducing their cost.

Solar screens and films applied directly to the window are an alternative means of reducing cooling loads by blocking solar radiation. Normally relatively inexpensive ( $\$ 7$ - $\$ 25$ per window), they can be quite cost effective. However, solar screens can significantly reduce visibility while films can alter the hue of light passing through them or, over time, develop air bubbles or become scratched, further obscuring the view. Films with a shading coefficient (SC) as low as 0.25 exist, but would darken a room and appear unattractive from the exterior. Cummings (1989) suggests using films with a shading coefficient between 0.5 and 0.7 . Solar screens offer an advantage over films in that, depending on their installation, they can be removed during the heating season whereas films applied directly to the glazing cannot.

Shading of east and west windows with vegetation can be very effective, though time is required for vegetation to grow to sufficient size. Though not particularly applicable to retrofit, deciduous trees provide excellent shading, not only on the sides of a house, but also on the roof. Also, by loosing their leaves during the heating season, these trees allow the sun to help reduce heating loads.

The best choice of strategy for shading in any particular situation will depend on the local relative costs of the strategies, the climate, physical location of the house, and the preferences of the occupants. Because of the potential to affect the view out windows, occupants should always be consulted before installing shading.

\section{Performance/Field Studies}

The Florida Program ranks window films and solar screens as "very cost-effective" in the southern third of the state and "generally cost-effective" elsewhere in the state. Shutters and landscaping are seen as "generally cost-effective" in the southern third of the state but only "somewhat" in the rest of the state. Due primarily to their cost, metal awnings are only "generally cost-effective" in the southern two-thirds of the Florida. Estimates of annual savings for films, solar screens, and awnings range from $\$ 13$ to $\$ 39$ per $60 \mathrm{ft}^{2}$ of window shaded. Cost estimates per $60 \mathrm{ft}^{2}$ of window area are given as $\$ 90, \$ 120$, and $\$ 350$ for films, solar screens, and awnings, respectively (Cummings 1989).

In Louisiana, solar screens and films are recommended by a residential energy education program. The program claims that cooling loads may be reduced by $10 \%-20 \%$. Savings were estimated at $5.6 \mathrm{kWh} / \mathrm{ft}^{2}$ for west facing windows, and $3.7 \mathrm{kWh} / \mathrm{ft}^{2}$ for east or north facing windows. (For comparison with the Florida results and those in Table A.25, these savings are equivalent to $\$ 27$ and $\$ 18$ for $60 \mathrm{ft}^{2}$ of window area, using an electric rate of $\$ 0.08 / \mathrm{kWh}$.) Average per house savings were $900 \mathrm{kWh}$ per year (Audette 1992). Only a slight increase in lighting use by tenants, $3 \%-5 \%$, was necessary to accommodate for the reduction in indoor lighting levels.

Several studies on the results of shade trees have reported positive results. In the southwest, plentiful landscaping was found to reduce cooling energy as much as $30 \%$ and proved to be cost-effective, despite the need for water conservation. Reports that cooling consumption has been reduced by $27 \%$ with shrubbery in Tucson, by $58 \%$ with shrubs and trees in Miami, and by $37 \%$ with trees in Sacramento, suggest that the savings can be significant (McPherson 1995). Computer simulations performed found that energy savings were higher for buildings with little or no insulation. A Florida program constructing low-income housing for victims of Hurricane Andrew will use landscaping to reduce cooling loads. 


\section{Other Considerations}

- Solar screens and films should be the material of choice for most applications, although awnings are an acceptable alternative if cost effectiveness can be clearly demonstrated.

- Occupants should always be consulted before installing shading which would affect their view out of windows. Shading should be an important component of occupant education in southern programs, especially if moveable shading materials are being installed.

- Savings are only achieved if air conditioners are present and used, or it can be demonstrated that the installation of shading will displace the future use of air conditioners. Shading will make indoor conditions more tolerable in homes that are not air conditioned, although no "energy savings" will occur.

\section{Estimates of Potential Savings}

NEAT, a variable-base, degree-day method (Sharp 1995) was used to expand the above results reported for Florida and Louisiana. Savings from installation of films, solar screens, and awnings were determined for two Florida cities and one Louisiana city to compare with those reported in the literature. Fair agreement lent confidence to the extension to other climates. Table A.25 shows the results for 16 U.S. cities in the southern states. The analysis assumed costs of $\$ 2$ and $\$ 3$ per square foot of window area for films and solar screens, respectively, and $\$ 87.50$ for installation of awnings over a $15 \mathrm{ft}^{2}$ window. Films were assumed left on the entire year, while solar screens were modeled with and without their removal in the winter. Heating was assumed supplied by a natural gas furnace at $70 \%$ efficiency. Results for use of heat pumps would be similar, but electric resistance heat would further penalize films and shade screens if left on during the winter. An electric price of $\$ 0.08 / \mathrm{kWh}$ was assumed. 
Table A.25. Annual dollar savings ${ }^{1}$ and savings-to investment ratios for window shading devices

\begin{tabular}{|l|c|c|c|c|}
\hline \multicolumn{1}{|c|}{ City } & Films & \multicolumn{2}{|c}{ Solar screens (\$/yr, SIR) } & Awnings \\
& $(\$ / y r$, SIR) & On in winter & Off in winter & (\$/yr, SIR) \\
\hline Miami & $\$ 42.49,1.98$ & $\$ 35.38,1.84$ & $\$ 37.55,1.97$ & $\$ 29.51,0.68$ \\
\hline Tallahassee & $\$ 15.79,0.69$ & $\$ 23.59,0.75$ & $\$ 38.11,1.34$ & $\$ 29.46,0.44$ \\
\hline New Orleans & $\$ 17.49,0.77$ & $\$ 16.37,0.78$ & $\$ 25.55,1.34$ & $\$ 19.55,0.44$ \\
\hline Houston & $\$ 16.41,0.72$ & $\$ 15.39,0.74$ & $\$ 24.40,1.28$ & $\$ 18.62,0.42$ \\
\hline Atlanta & $\$ 0.58,0.05$ & $\$ 4.79,0.14$ & $\$ 18.29,0.96$ & $\$ 11.01,0.23$ \\
\hline Charleston & $\$ 7.48,0.29$ & $\$ 9.36,0.40$ & $\$ 20.85,1.10$ & $\$ 14.37,0.32$ \\
\hline Raleigh & $\$-2.79,-0.21$ & $\$ 2.46,0.01$ & $\$ 16.83,0.88$ & $\$ 8.57,0.17$ \\
\hline Memphis & $\$ 7.28,0.27$ & $\$ 9.64,0.40$ & $\$ 22.57,1.19$ & $\$ 15.29,0.33$ \\
\hline Montgomery & $\$ 8.83,0.35$ & $\$ 10.80,0.47$ & $\$ 22.52,1.18$ & $\$ 16.19,0.36$ \\
\hline Shreveport & $\$ 11.03,0.45$ & $\$ 12.15,0.54$ & $\$ 24.23,1.27$ & $\$ 17.67,0.39$ \\
\hline OK City & $\$ 1.15,0.04$ & $\$ 5.64,0.16$ & $\$ 21.94,1.15$ & $\$ 12.75,0.27$ \\
\hline Dallas & $\$ 10.81,0.44$ & $\$ 12.06,0.53$ & $\$ 25.18,1.32$ & $\$ 17.77,0.39$ \\
\hline Albuquerque & $\$-3.86,-0.17$ & $\$ 0.89,-0.13$ & $\$ 22.58,1.19$ & $\$ 11.23,0.22$ \\
\hline Phoenix & $\$ 33.61,1.52$ & $\$ 29.67,1.47$ & $\$ 40.84,2.15$ & $\$ 37.53,0.73$ \\
\hline Las Vegas & $\$ 18.67,0.79$ & $\$ 18.33,0.82$ & $\$ 35.44,1.86$ & $\$ 27.05,0.60$ \\
\hline Los Angeles & $\$-8.61,-0.49$ & $\$ 4.57,-0.37$ & $\$ 10.79,0.57$ & $\$ 1.65,0.01$ \\
\hline
\end{tabular}

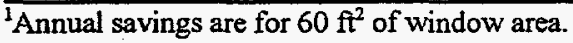

Leaving the shading devices on all year round prevents most measures from being cost effective except in the hottest or sunniest climates, like Miami and Phoenix. However, permitting removal of the shading device in the winter months allows cost-effectiveness in most climates except Los Angeles.

\section{References}

Audette, J., "Trends: Residential Education Program," Home Energy," July/Aug 1992 p.12.

Cummings, James B., John J. Tooley Jr., and Neil A. Moyer, Florida Fix Weatherization Training Manual, Florida Solar Energy Center, FSEC-GP-42-89, October 1989.

Krigger, John T., Your Home Cooling Energy Guide, Saturn Resource Management, 1991.

Lechner, Norbert, 1991. Heating, Cooling, Lighting: Design Methods for Architects, John Wiley \& Sons, NY, NY.

McPherson, G., Simpson, J., "Shade Trees as a Demand-Side Resource," Home Energy, Mar/Apr 1995. 
Means, 1996. Means Repair \& Remodeling Cost Data, 17th Edition, R.S. Means Co., Kingston, MA.

Meier, Alan, "Using Water to Save Energy," Home Energy, Jul/Aug 1989, pgs 23-27.

Nisson, J.D., "After the Hurricane: Energy-Retrofitting South Florida," Energy Design Update, April, 1993.

Sharp, Terry, "Measuring the Performance of the National Energy Audit," Home Energy, May/June 1995.

Warner, J.L., "Consumer Guide to Energy-Saving Windows," Home Energy, July/August 1990, pg. 20. 


\section{SKIRTING}

\section{Technology Description}

Homes which stand on pillars or stilts having their underside (floor) open to the outdoors, such as manufactured housing (mobile homes), can have the area between their floor and the ground enclosed by the installation of a skirting around the perimeter of the home. The skirting may be metal or plastic and sometimes insulated, possibly with bead-board (polystyrene).

Although the placement of skirting (insulated or otherwise) is more commonly applied to manufactured housing, the existence of site-built homes in warm climates with exposed floors makes this option potentially applicable for these homes as well.

Key to any energy savings from this option is how well the skirting fits in preventing air from leaking into the area it encloses. Without a tight fit, the only energy-related benefit possible would be the reduction in the heat transfer coefficient of the structure's floor due to the decreased wind speed it experiences. Counter to allowing such a tight fit are local codes which can require crawlspaces to be vented.

Factors mentioned by auditors related to the need for insulated skirting include the placement of water pipes and their potential for freezing if floor insulation is installed instead of insulated skirting. Increased customer satisfaction from the visibility of the skirting once installed has also been indicated. Pest control can also be an advantage of skirting.

\section{Performance / Field Studies}

Tests performed by the National Renewable Energy Laboratory (NREL) (Judkoff 1988 \& 1991) provide estimates of the effectiveness of adding skirting. The tests were performed on mobile homes in a controlled environment test facility. The chamber allows controlling the temperature surrounding the home and the monitoring of heat loss from the structure. The facility was used to test the difference in heat loss from the structure with and without tight-fitting insulated skirting under still air conditions and with a simulated $3.5 \mathrm{mph}$ wind speed. Results show decreases in heat loss of 46 and $53 \mathrm{Btu} / \mathrm{h}-{ }^{\circ} \mathrm{F}$ respectively for the two cases. In comparison, addition of belly insulation (similar to adding floor insulation to a site-built home) had decreases of 47 and $75 \mathrm{Btu} / \mathrm{hr}-\mathrm{F}$, respectively.

The conclusions of the study were that "belly insulation is much more cost-effective than skirting in calm or windy conditions" since "the installed cost for insulated or uninsulated skirting in the Denver area is greater than that for a belly blow." However, the same conclusion may not directly apply for site-built homes because the cost of floor insulation may be greater than for blowing insulation into the belly of a mobile home.

The test described looked at the effect of skirting under heating conditions. This is the case where the majority of savings would accrue. As the climate becomes warmer, this savings would decrease. Nevertheless, an argument can be presented to attribute some additional cooling energy savings stemming from further isolation of the floor from the hot outdoor air with more direct coupling to the cooler ground during the cooling season. No tests or data could be found quantifying this savings, though. Ground coupling is one of the weakest areas in modeling techniques making computational efforts questionable. In addition, it can be assumed that the reduction in heating savings as the climate becomes warmer would more than compensate for this possible increase in cooling savings. 


\section{Estimates of Savings Potential}

The above indicated reduction in heat loss reported for skirting can be used to estimate the savings resulting from addition of skirting in other climates. The results of Table A.26 use a modified heating degree-day method to compute the approximate savings from installing skirting. They assume a $50 \mathrm{Btu} / \mathrm{hr}-{ }^{\circ} \mathrm{F}$ reduction in the heat loss; 70\% efficient furnace or a heat pump with heating seasonal performance factor (HSPF) of 6.5; fuel prices of $\$ 5.95 / \mathrm{MBtu}$ and $\$ .08 / \mathrm{kWh}$ for gas and electric, respectively; and a measure life of 7 years. The average cost of $\$ 300$ per home for installing skirting, as reported by a weatherization agency in the southeast, will be used to compute the SIR below.

Table A.26. Energy and cost savings, and SIR's for skirting

\begin{tabular}{|c|c|c|c|c|c|c|}
\hline \multirow[b]{2}{*}{ City } & \multicolumn{2}{|c|}{ Natural Gas Heat } & \multicolumn{2}{|c|}{ Electric Resistance Heat } & \multicolumn{2}{|c|}{ Heat Pump Heat } \\
\hline & $\begin{array}{c}\text { Heating Savings, } \\
\text { MBtu, } \\
\text { S/yr }\end{array}$ & SIR & $\begin{array}{c}\text { Heating Savings, } \\
\mathbf{k W h} \\
\mathbf{\$} / \mathbf{y r}\end{array}$ & SIR & $\begin{array}{c}\text { Heating Savings, } \\
\mathbf{k W h} \\
\mathbf{S / y r}\end{array}$ & SIR \\
\hline Miami & $0.22 \mathrm{MBtu}, \$ 1$ & 0.03 & $45 \mathrm{kWh}, \$ 4$ & 0.07 & $24 \mathrm{kWh}, \$ 2$ & 0.04 \\
\hline New Orleans & 1.42 MBtu, \$8 & 0.18 & $292 \mathrm{kWh}, \$ 23$ & 0.47 & $154 \mathrm{kWh}, \$ 12$ & 0.25 \\
\hline Houston & 1.44 MBtu, \$9 & 0.19 & $294 \mathrm{kWh}, \$ 24$ & 0.47 & $155 \mathrm{kWh}, \$ 12$ & 0.25 \\
\hline Atlanta & 3.05 MBtu, \$18 & 0.39 & $625 \mathrm{kWh}, \$ 50$ & 1.00 & $329 \mathrm{kWh}, \$ 26$ & 0.53 \\
\hline Charleston & $2.09 \mathrm{MBtu}, \$ 12$ & 0.27 & $429 \mathrm{kWh}, \$ 34$ & 0.69 & $226 \mathrm{kWh}, \$ 18$ & 0.36 \\
\hline Raleigh & $3.49 \mathrm{MBtu}, \$ 21$ & 0.45 & $716 \mathrm{kWh}, \$ 57$ & 1.15 & $377 \mathrm{kWh}, \$ 30$ & 0.60 \\
\hline Memphis & $3.32 \mathrm{MBtu}, \$ 20$ & 0.43 & $682 \mathrm{kWh}, \$ 55$ & 1.09 & $359 \mathrm{kWh}, \$ 29$ & 0.57 \\
\hline Montgomery & $2.36 \mathrm{MBtu}, \$ 14$ & 0.31 & $483 \mathrm{kWh}, \$ 39$ & 0.77 & $254 \mathrm{kWh}, \$ 20$ & 0.41 \\
\hline Shreveport & $2.25 \mathrm{MBtu}, \$ 13$ & 0.29 & $461 \mathrm{kWh}, \$ 37$ & 0.74 & $242 \mathrm{kWh}, \$ 19$ & 0.39 \\
\hline Oklahoma City & 3.83 MBtu, \$23 & 0.50 & $786 \mathrm{kWh}, \$ 63$ & 1.26 & $414 \mathrm{kWh}, \$ 33$ & 0.66 \\
\hline Dallas & 2.43 MBtu, \$14 & 0.32 & $499 \mathrm{kWh}, \$ 40$ & 0.80 & $262 \mathrm{kWh}, \$ 21$ & 0.42 \\
\hline Albuquerque & 4.47 MBtu, \$27 & 0.58 & $917 \mathrm{kWh}, \$ 73$ & 1.47 & $483 \mathrm{kWh}, \$ 39$ & 0.77 \\
\hline Phoenix & $1.82 \mathrm{MBtu}, \$ 11$ & 0.24 & $372 \mathrm{kWh}, \$ 30$ & 0.60 & $196 \mathrm{kWh}, \$ 16$ & 0.31 \\
\hline La s Vegas & 2.79 MBtu, \$17 & 0.36 & $571 \mathrm{kWh}, \$ 46$ & 0.91 & $301 \mathrm{kWh}, \$ 24$ & 0.48 \\
\hline Los Angeles & $2.12 \mathrm{MBtu}, \$ 13$ & 0.27 & $435 \mathrm{kWh}, \$ 35$ & 0.70 & $229 \mathrm{kWh}, \mathrm{S18}$ & 0.37 \\
\hline
\end{tabular}




\section{References}

Judkoff, Ron, et al., "Mobile Home Weatherization Measures: A Study of Their Effectiveness," SERI/TR-2543440, December 1988.

Judkoff, Ron; "Mobile Home Retrofits Revisited: CMFERT Phase II," Home Energy, Jan/Feb 1991, pgs. 21-24.

Palmer, Larry, Arkansas Weatherization Program, Personal communication. 


\section{SOLAR WATER HEATING}

\section{Technology Description}

Water heating is estimated to account for approximately $14 \%$ of all residential energy use in Florida (SRC 1992) and is likely of a similar magnitude in other southeastern states. However, data from a submetered low income development in South Florida suggests that the fraction of overall energy end use for water heating in low income homes may be significantly greater than average due to a higher occupant density leading to increased hot water consumption (Parker et al. 1994). According to EIA residential energy consumption data (1993), water heating accounts for $17 \%-39 \%$ of the end-use energy consumed within the five warm climate subregions studied.

Solar water heating is a proven means of reducing energy use related to water heating. Passive and active solar collectors use sunlight to heat water to suitable temperatures to provide domestic hot water. Passive systems do not require external energy for operation and some may take advantage of thermosiphoning for water circulation. Active systems utilize small pumps, sensors and heat exchangers to heat and circulate the water. Both systems are technically feasible on most homes with an unobstructed southern exposure; and have: an expected lifetime of 20 years. Some limitations may include roof geometry and conditions, attic access for plumbing and age of auxiliary water tank if to be used by the solar system.

Solar water heating is a mature alternative energy technology. The newest generation of water heating systems are more simple and reliable than earlier equipment. Innovative advanced passive designs may use highefficiency evacuated tube, heat pipe or closed-loop phase change systems (Bancroft et al. 1991). However, much of recent innovation efforts have centered on reducing cost and improving reliability rather than centering on thermal performance alone. Photovoltaic pumped active systems can both increase system reliability while cutting auxiliary pumping energy. In locations where freezing weather is not a problem, open systems without a heat exchanger can be utilized.

Considerable attention in Florida has focused on development of lower cost solar water heating systems to make solar more attractive. For instance, organizers of the Solar Weatherization Assistance Program (SWAP) in Florida anticipate installed systems costing generally less than $\$ 1,600$ each which will use $20-24$ square foot collectors while utilizing existing 40 or 50 gallon electric water heater tanks (SRC 1994). Similar low-cost systems with a heat exchanger and freeze protection have been proposed and are feasible (Quillen 1992). Regardless, a comparison done by ACEEE estimates that over a 13 year period, including material, installation and energy costs, a $\$ 2,500$ solar heater with an electric backup would cost $40 \%$ less to own and operate than a conventional electrical storage system (Wilson 1995).

An economic assessment is a fundamental part of potential acceptance of solar water heating as a weatherization measure. Since installed solar systems typically cost in excess of $\$ 1,200$, economics will depend to a large extent on the competing auxiliary fuel price. Typically, solar systems cannot compete in life cycle cost with natural gas fueled installations. However, it can be quite competitive for those with higher priced electricity, propane or fuel oil. Installations should be individually cost-justified with assurance that occupants can provide necessary maintenance.

\section{Performance/Field Studies}

The savings potential of solar water heaters in Florida has been well researched. Merrigan's study of 20 Florida solar water heating systems in 1982 found an average coefficient of performance of 2.35 relative to 0.82 for 18 electrical resistance systems. This implies a $65 \%$ reduction in electrical use relative to standard water heaters, which were measured to use approximately $3,000 \mathrm{kWh}$ annually in Florida (Merrigan 1983). Twenty- 
four monitored systems in North Carolina had an estimated annual savings of $52 \%$ or $2,270 \mathrm{kWh}$. The Tennessee Valley Authority (TVA) initiated a major solar water heating project in 1978 (Chaffin et al. 1982). Measured average savings varied from 2,100 - 2,698 kWh in 25 measured systems in the Nashville and Memphis areas, respectively. In Texas, the City of Austin monitored the performance of 15 solar systems against 15 conventional electric resistance water heaters beginning in 1981 (Askey and Vliet 1984). Solar water heaters in that study saved $2,813 \mathrm{kWh}$, or $52 \%$ of the energy consumed by the conventional electric heaters.

More modern units may offer improved reliability and performance at a lower expense. Smaller, more cost effective solar water heating systems have the potential to provide half of the energy necessary for water heating. One unit, which won the Florida Governor's challenge to build a low-cost water heating system, sells for only about $\$ 700$, is designed to provide $95 \%$ of water heating for a household of two and $50 \%$ for a home with four members. Although it can be self-installed, professional installation is assumed to add $\$ 350$ to the price. Savings should average approximately $70 \%$ in a three person household. Preliminary results indicated an annual savings of $\$ 165$, or $2,062 \mathrm{kWh}$ assuming an energy cost of $\$ 0.08 / \mathrm{kWh}$ (Kelsey 1993).

\section{Other Considerations}

- Experience adding solar water heating systems to residences has been extensive in the southeastern U.S. although not mainly as a weatherization measure. The SWAP project in Florida (SRC 1994) is installing 1,000 solar water heaters over the next three years and should provide considerable experience with solar as an energy efficiency measure.

- Some concern rests in the ability for low-income families to provide any required maintenance of the systems necessary to retain predicted performance.

- Addition of solar water heating systems should be combined with measures to improve existing hot water system efficiency (low flow showerheads, external tank wrap and pipe insulation).

- According to one manufacturer, systems that are installed properly should be fairly reliable. Some problems that may occur with poorly installed solar heaters include: failure of controller sensors (within 2-3 years) and pump failure (within 5-10 years). For closed-loop systems utilizing anti-freeze, the manufacturer recommends flushing the closed loop side out every 5 years, to prevent corrosion (Thermomax 1996). 


\section{Estimates of Potential Savings}

Table A.27 lists estimates of annual savings for small and large solar water heaters. These estimates are based on average reported savings from field studies and literature.

Table A.27. Estimated consumption and cost savings, and SIR associated with retrofitting electric water heaters with small and large solar heating systems

\begin{tabular}{|c|c|c||}
\hline \multirow{2}{*}{ Climate } & \multicolumn{2}{|c|}{ Energy Savings of Solar Water Heaters } \\
& $\begin{array}{c}\text { Small Solar System* } \\
\text { (kWh, \$/yr, SIR) }\end{array}$ & $\begin{array}{c}\text { Large Solar System** } \\
\text { (kWh, \$/yr, SIR) }\end{array}$ \\
\hline Gulf & $\begin{array}{c}2,060 \mathrm{kWh}, \\
\$ 165,2.19\end{array}$ & $\begin{array}{c}2,626 \mathrm{kWh}, \\
\$ 210,1.17\end{array}$ \\
\hline Humid & not available & $\begin{array}{c}1,773 \mathrm{kWh}, \\
\$ 142,0.79\end{array}$ \\
\hline Dry & not available & $\begin{array}{c}2,675 \mathrm{kWh}, \\
\$ 214,1.19\end{array}$ \\
\hline Central & not available & $\begin{array}{c}2,675 \mathrm{kWh}, \\
\$ 214,1.19\end{array}$ \\
\hline Pacific & not available & $\begin{array}{c}2,954 \mathrm{kWh}, \\
\$ 236,1.31\end{array}$ \\
\hline
\end{tabular}

* Based on reported savings from preliminary field tests

** Based on extrapolation of averaged reported savings of $56 \%$ to EIA regional end-use consumption data

1) Small systems cost $\$ 1,050$, large systems cost $\$ 2,500$, expected lifetime is a maximum of 20 years

2) Cost savings based on electricity costs of $8 \notin / \mathrm{kWh}$

\section{References}

"A Cheaper Solar Water Heater," Home Energy, May/June, 1993, p. 10.

Askey, J.L., and Vliet, G.C., 1984. "The Influence of Residential Solar Water Heaters on Electric Utility Peak Demand," Solar Engineering- 1984, Proceeding of the ASME Solar Energy Division Sixth Annual Conference, American Society of Mechanical Engineers, NY.

Bancroft, B., Shepard, M., Lovins, A.B. and Bishop, R.C., 1991. State of the Art Technology Atlas for Water Heating, E-Source, Inc., Boulder, CO.

EPRI, 1985. Electric Water Heating for Single Family Residences: Group Load Research and Analysis, EPRI EA-4006, Electric Power Research Institute, Palo Alto, CA.

Chaffin, D.J., Askew, G.L., Fine, D.N. and Wessling, F.C., 1982. "Results of TVA Monitoring of Residential Solar Water Heaters," Proceedings of the Solar Hot Water Field Test Technical Review Meeting, Tennessee Valley Authority, Solar Applications Branch, July 14-15, 1982.

EIA, 1993, Household Energy Consumption and Expenditures 1990, Energy Information Administration, DOE/EIA-0321 (90), February 1993.

Florida Solar Energy Center, 1994. "FSEC Approved Solar Energy Systems: Domestic Hot Water and Pool 
Heating," FSEC-GP-15-1994, Cape Canaveral, FL.

Kelsey, P.A., “A Cheaper Solar Heater," Home Energy Magazine, May/June 1993, Vol. 10, No. 3.

Merrigan, T., 1983. Residential Conservation Demonstration: Domestic Hot Water, Final Report, FSEC-CR-8129(RD), Florida Solar Energy Center, Cape Canaveral, FL.

Merrigan, T., 1986. Data Acquisition Program: Solar Domestic Hot Water Systems, Final Report prepared for the North Carolina Alternative Energy Corporation, FSEC-CR-147-86, Florida Solar Energy Center, Cape Canaveral, FL.

Parker, D., Barkaszi, S., Sherwin, J. and Richardson, C., 1994. Demonstration of Energy Efficient Affordable Housing at the Jordan Commons Project, FSEC-CR-735-94, Florida Solar Energy Center, Cape Canaveral, FL.

Quillen, C.M., 1992. Low Cost Solar Water Heater Competition, "Low Cost Solar Water Heater," proposal from Virginia Solar Components, Rustburg, VA, (800-763-0500) Second Quarterly Report, prepared for Florida Energy Office, Grant \#70622, Florida Solar Energy Center, Cape Canaveral, FL, July, 1992.

SRC, 1992. Electricity Conservation and Energy Efficiency in Florida: Phase I Report, SRC Report No. 7777-R3, p. IV-21, prepared for the Florida Energy Office, Tallahassee, FL, June, 1992.

SRC, 1994. "Florida's Solar Weatherization Assistance Program," The DSM Letter, May 23, 1994, Synergic Resources Corporation, Bala Cynwd, PA.

Thermomax, 1996. Telephone conversation with vendor, 1/18/96, 1-410-997-0778.

Wilson, A., Morrill, J., 1995. Consumer Guide to Home Energy Savings, ACEEE, Washington, D.C. 


\section{STORM WINDOWS}

\section{Technology Description}

Storm windows save energy by reducing conduction losses through the primary window glass and frame. If properly fit, storm windows can also reduce infiltration around a window if the window cannot be sealed in any other way. Interior storms can be effective over leak-prone louvered windows on which exterior storms cannot be installed. During the heating season, storm windows will also raise the surface temperature of the inside surface of the existing window, increasing the radiant temperature felt by the occupants. Under extremely hot and humid conditions, they may decrease condensation on the outside of windows in air-conditioned homes.

Installation of storm windows may be a less costly alternative to replacing the primary window unit when this unit is damaged beyond repair or cannot be sealed satisfactorily. However, placing a storm window over a dysfunctional primary window may be objectionable to the occupants, prevent natural ventilation, or result in moisture accumulation between the primary and storm windows possibly contributing to rotting.

The cost effectiveness of adding storm windows in cooling climates is difficult to estimate. Savings from reducing conduction losses alone are normally insufficient to warrant their use. If reduced infiltration is also accomplished by their installation, added savings during the heating season will occur, with the amount of savings heavily dependent on the condition of the primary window. Cooling savings from reduced infiltration associated with storm window installation is even less easily determined. Such savings will depend on the extremes of outdoor air temperature, the humidity of the air, whether the occupants use natural ventilation together with airconditioning, and the duration of the "swing" season at the location. If installation of storm windows prevent use of natural ventilation, cooling consumption may increase.

Other factors affecting storm window savings include the condition of the existing window, the cost of installation, which varies considerably, and the quality of installation. Single-pane windows with metal frames having no thermal break benefit most from application of storm windows. Some weatherization groups have manufactured their own windows, for a considerably lower cost.

Installation of plastic sheeting over existing windows is, at best, a temporary measure. The plastic reduces visibility through the window and will most likely be removed when warmer weather arrives. Even if allowed to remain, most plastic sheeting deteriorates with time and exposure to sunlight. Sealing of the plastic is difficult, yet necessary if any benefit is to be derived.

\section{Performance / Field Studies}

The cost-effectiveness of adding storm windows based on decreased conduction losses alone appear to be marginal even in colder climates. The Florida Weatherization Program recommends their installation in northern Florida only, estimating an annual savings of $\$ 90$. However in Virginia, auditors failed to indicate their costeffectiveness.

Though not performed in a primarily cooling climate, a study by the Massachusetts Audubon Society examining the benefits of installing storm windows in that state's low-income Weatherization Program adds insight (Nadel 1986). Here, installation of storms on all windows of eleven homes produced an average annual savings of $\$ 119$ per home in heating while costing an average of $\$ 720$. Installed costs per unit ranged from $\$ 43$ to $\$ 55$. Since the energy savings result from metered data, they include the effects of both conduction and infiltration reduction associated with the installation of the storms windows. Total savings in warmer climates would be expected to be smaller. The Massachusetts study concludes, "Storm windows are cost-effective energy 
savers [for this climate], but given their relatively high cost, the fact that they are not always used properly, and the fact they are exposed to the elements and deteriorate over time, they are not as cost-effective as many other weatherization measures." Thus, the study gives this option a low priority, except where "a storm window will provide critical protection to a primary window."

A comparative analysis of thirty different weatherization program evaluations, mostly from heating climates, showed estimated simple payback for installation of storm windows and "other unspecified measures" ranging from 16 to 27 years (Meridian 1989).

\section{Estimates of Savings Potential}

The following estimates of savings from installing a storm window over a $3 \times 4 \mathrm{ft}$. primary window were produced using degree-day calculations. Savings for decreased conduction through the window assembly are included for both heating and cooling seasons. However, only heating savings from decreased infiltration are included due to the uncertain affect of the reduced leakage under cooling conditions. The infiltration estimates are based on an ASHRAE procedure (ASHRAE 1979) assuming the storm reduces the infiltration characteristics of the window assembly from fairly "loose" to "average" over an average window orientation with respect to a $7.5 \mathrm{mph}$ wind. These assumptions lead to an air leakage reduction estimate of $0.14 \mathrm{CFM}$ per foot of crack. The calculations were performed with weather from typical cities in each climate subregion. SIR's were determined assuming a 15 year life. Depending on the quality of the storm window installed, this may be too optimistic. An installed cost of $\$ 50$ per window has been used.

Table A.28. Energy and cost savings, and SIR's for storm window installation

\begin{tabular}{|c|c|c|c|c|c|c|c|c|}
\hline \multirow{3}{*}{$\begin{array}{l}\text { Climate } \\
\text { Region }\end{array}$} & \multicolumn{4}{|c|}{ Natural Gas Heat } & \multicolumn{4}{|c|}{ Electric Resistance Heat } \\
\hline & \multicolumn{2}{|c|}{ Storm Only } & \multicolumn{2}{|c|}{ Storm + Infiltration } & \multicolumn{2}{|c|}{ Storm Only } & \multicolumn{2}{|c|}{ Storm + Infiltration } \\
\hline & $\begin{array}{c}\text { Savings } \\
\$ / y \mathbf{r}\end{array}$ & SIR & Savings $\mathbf{S / y r}$ & SIR & $\begin{array}{c}\text { Savings } \\
\text { S/yr }\end{array}$ & Sir & $\begin{array}{c}\text { Savings } \\
\$ / \mathbf{y r}\end{array}$ & SIR \\
\hline Humid & 2 & 0.48 & 3 & 0.61 & 4 & 0.84 & 6 & 1.40 \\
\hline Gulf & 1 & 0.38 & 2 & 0.39 & 2 & 0.46 & 3 & 0.69 \\
\hline Dry & 2 & 0.64 & 3 & 0.77 & 4 & 0.98 & 7 & 1.59 \\
\hline Central & 2 & 0.54 & 3 & 0.64 & 4 & 0.84 & 6 & 1.38 \\
\hline Pacific & 1 & 0.20 & 1 & 0.31 & 2 & 0.34 & 3 & 0.72 \\
\hline
\end{tabular}

Estimates for the effects of infiltration reduction can vary widely depending on the condition of the primary window. Leakage rates obtained by various methods found in the literature and measured under laboratory conditions ranged by a factor of 16 from the minimum to a maximum. Results above would be significantly conservative if applied to a very leaky primary window. The final decision to install a storm window should include consideration of other factors discussed above as well as alternative methods for correcting the energy inefficient characteristics of the window assembly. 


\section{References}

ASHRAE, 1979. Cooling and Heating Load Calculation Manual, ASHRAE, Atlanta, GA.

Cummings, James B., John J. Tooley Jr., and Neil A. Moyer, Florida Fix Weatherization Training Manual, Florida Solar Energy Center, FSEC-GP-42-89, October 1989.

Greely, Kathy, John Randolph, and Bill Hill, "A Warm Wind Blows South: Virginia's Weatherization Evaluation," Home Energy, Jan/Feb 1992, p.15.

Meridian Corporation, Weatherization Evaluation Findings: A Comparative Analysis, April 30, 1989.

Nadel, Steven and Mitchell Heineman, "Fuel Savings Achieved By 'House Doctoring' and Storm Windows in Massachusetts Low-Income Homes: Final Report", Mass. Audubon Society \& Executive Office of Communities and Development, November 1986. 


\section{WALL INSULATION}

\section{Technology Description}

Insulating walls saves energy by reducing heat flow through the wall surfaces. The same materials and installation methods can be used in southern houses as are used in other parts of the country. DOE guidelines, listed in the Insulation Fact Sheet (1988), suggest that wall insulation levels of R-11 to R-13 are appropriate for most U.S. climates. ${ }^{7}$ Exceptions include homes using fuel oil, natural gas, or electric heat pumps for heating in the extreme southern parts of Florida, Texas, and California. Justification for recommended levels of wall insulation will be based largely on achieved heating energy savings as cooling energy savings may not be as significant.

Selecting the proper approach for adding wall insulation to a home is highly dependent on the existing construction of the walls. Rigid foam insulation may be added to the exterior of masonry walls, however the practice is material and labor intensive (Ternes 1994). Filling the internal cavities of block walls with insulation is not recommended. Wood framed walls may be insulated by blowing cellulose fiber or loose fiberglass into the wall cavity via holes cut through the sidewall. Care must be taken to account for settling of blown in insulation as the infiltration through an unfilled air-space may contribute to a decrease in wall $\mathrm{R}$-value. For this reason, fiberglass density should be between 2.2 and $3.0 \mathrm{lb} / \mathrm{ft}^{3}$, and cellulose between 3.5 and $4.0 \mathrm{lb} / \mathrm{ft}^{3}$ (Krigger 1994). To ensure maximum energy performance, experienced installers should be sought to perform the installation.

Choosing the appropriate amount of insulation to add to existing levels is important. Table A.29 lists the thicknesses required to obtain R-values of 11 and 19, for some typical blown-in materials. Existing levels may be detected through inspection of exposed electrical wall outlets. Additionally, software such as the National Energy Audit (NEAT) and ZIP are useful for states and agencies to make program decisions using local information at the house level (if desired).

Table A.29. Physical thickness of insulation and corresponding R-value (ORNL 1996, Krigger 1994).

\begin{tabular}{|c|c|c|c|}
\hline \multirow{2}{*}{$\begin{array}{c}\text { Blown-In } \\
\text { Insulation Type }\end{array}$} & \multicolumn{2}{|c|}{ Achieved Insulation Level (Inches) } & \multirow{2}{*}{$\begin{array}{c}\text { Required } \\
\text { Density } \\
\left(\mathrm{lb} / \mathrm{ft}^{3}\right)\end{array}$} \\
\hline & $\begin{array}{c}\mathrm{R}-11 \\
\left(\mathrm{hr}-\mathrm{ft}^{2}-{ }^{\circ} \mathrm{F} / \mathrm{Btu}\right)\end{array}$ & $\begin{array}{c}\mathrm{R}-19 \\
\left(\mathrm{hr}-\mathrm{ft}^{2}-{ }^{\circ} \mathrm{F} / \mathrm{Btu}\right)\end{array}$ & \\
\hline Fiberglass & $4-5$ & $7-9$ & $2.2-3.0$ \\
\hline Cellulose & 3 & 6 & $3.5-4.0$ \\
\hline
\end{tabular}

Concern has been expressed that the high humidity in the southeast may lead to moisture problems in houses retrofitted with high-density wall insulation. The Moisture Control Handbook (Lstiburek and Carmody 1991) suggests wall constructions be specifically designed for moisture control in cooling climates. This includes providing paths for air movement, either to the outside or inside of the house, to ensure proper drying of the wall materials throughout the year. Existing walls whose constructions follow the principles described in the publication should have less moisture problems associated with insulating. Wet applied wall insulations in cooling climates may require special attention.

\footnotetext{
${ }^{7}$ DOE will be releasing a new Insulation Fact Sheet in 1997. The new information will use updated fuel and materials costs to recommend optimal levels of insulation.
} 
The cost effectiveness of this measure in a specific case will depend on the local climate, amount of existing insulation, and the cost of installation, which can vary widely. For insulation blown into wood frame walls, Means estimates costs for cellulose fills at $\$ 1.77 / \mathrm{ft}^{2}$ and for fiberglass fills at $\$ 1.97 / \mathrm{ft}^{2}$ (1996). The Virginia Weatherization Program reported a cost of $\$ 0.80 / \mathrm{ft}^{2}$ for high-density cellulose, at an average cost of $\$ 930$ per home (Randolph 1991). Reported costs for installation of exterior insulation to masonry houses ranges from $\$ 3.34 / \mathrm{ft}^{2}$ to $\$ 3.90 / \mathrm{ft}^{2}$ (Ternes 1994, Barkaszi 1995). Cost effectiveness should be based on heating energy savings as cooling savings may be small in comparison.

\section{Performance/Field Studies}

A recent study measured cooling energy savings from exterior wall insulation (using R-13 rigid boards) applied to masonry (block) homes in Phoenix. The sizes of the homes retrofitted ranged between $1,120 \mathrm{ft}^{2}$ and $1,585 \mathrm{ft}^{2}$ and average cooling energy savings were $491 \mathrm{kWh}$, or $9 \%$ (Ternes 1994). Using the results of the field study, computer models were developed to estimate cooling energy savings from exterior insulation for houses in other warm climates (McLain 1992). The results of this simulation are listed in Table A.30 for homes with R-19 and R-30 ceiling insulation. These data indicate that exterior wall insulation can potentially save $12 \%$ of cooling energy in an extremely hot climate like Phoenix, but have limited cooling savings in mild, seacoast regions like Florida. The modeling also predicted an average reduction in heating energy consumption of $30 \%$, for most climates.

Cooling energy savings appear to be affected by several factors: (1) climatic temperature extremes., (2) thermal characteristics of the house, and (3) the habits of the occupants. In mild climates that do not experience frequent temperature extremes, the addition of insulation prevents release of heat generated internally or stored from solar heat gain received during the day. The massiveness of the house also affects the rate and timing of the release of this heat and, therefore, the effect of the wall insulation.

The cost-effectiveness of applying insulation to block walls ultimately depends on how economically the insulation can be applied and the associated energy savings from the application for the specific climate of concern. The Phoenix study reported retrofit costs at $\$ 3.34 / \mathrm{ft}^{2}$, or $\$ 3,610$ to $\$ 4,550$ per house (Ternes 1994). At present, insulating block walls in cooling climates is generally not cost-effective unless performed as a part of a renovation program in which exterior wall improvement work is already being performed (Ternes and Wilkes 1993).

A recent field study in Central Florida found similar results for two homes retrofitted with exterior insulation (Barkaszi 1995). One house experienced a $9 \%-14 \%$ reduction in cooling energy consumption, while the other experienced a negative savings $(-5 \%)$. The variation in savings were believed to be due to differences in set point temperatures, as the savings were higher in the home with the lower air conditioning set point temperature. The report concluded that overall savings would be more attractive in homes with larger cooling demands, which may be predicted through the occupants' selection of lower cooling set point temperatures.

Other examples of wall insulation retrofit efforts are primarily found in Weatherization Programs. Historically, however, this work usually targets the reduction of heating costs, and generally cooling savings are not reported. The Virginia Weatherization Program, shown to be highly cost-effective in a recent evaluation, recommends high-density blown cellulose wall insulation (Randolph 1991). This approach ensures that infiltration can be addressed at the same time insulation is installed. The Florida Program admits that walls are not widely insulated in Florida. The Program "highly" recommends it for frame walls in the northern third of the state while recommending it only "sometimes" as "somewhat cost-effective" for frame houses in the southern third. 
Table A.30. Annual cooling energy savings associated with addition of exterior wall insulation, using R-13 (McLain 1992).

\begin{tabular}{|c|c|c|c|c|}
\hline \multirow{2}{*}{$\begin{array}{c}\text { Location of } \\
\text { Home }\end{array}$} & \multicolumn{2}{|c|}{ R-19 Ceiling Insulation } & \multicolumn{2}{|c|}{ R-30 Ceiling Insulation } \\
\hline & $\begin{array}{c}\text { Cooling Savings, } \\
\mathrm{kWh},(\%)\end{array}$ & $\begin{array}{l}\text { Average Cooling } \\
\text { Savings, } \$ / y r\end{array}$ & $\begin{array}{c}\text { Cooling Savings, } \\
\mathrm{kWh},(\%)\end{array}$ & $\begin{array}{l}\text { Average Cooling } \\
\text { Savings, } \$ / y r\end{array}$ \\
\hline El Toro, CA & $\begin{array}{c}30-41 \\
(4.2-7.5)\end{array}$ & $\$ 3$ & $\begin{array}{c}30-37 \\
(5.4-8.1)\end{array}$ & $\$ 3$ \\
\hline Atlanta, GA & $\begin{array}{c}68-91 \\
(4.9-8.4)\end{array}$ & $\$ 6$ & $\begin{array}{c}75-92 \\
(5.7-9.1)\end{array}$ & $\$ 7$ \\
\hline Albuquerque, NM & $\begin{array}{c}80-99 \\
(6.3-10.7)\end{array}$ & $\$ 7$ & $\begin{array}{c}85-98 \\
(7.1-11.4)\end{array}$ & $\$ 8$ \\
\hline Memphis, TN & $\begin{array}{l}183-191 \\
(7.8-9.8)\end{array}$ & $\$ 15$ & $\begin{array}{c}189-195 \\
(8.3-10.4)\end{array}$ & $\$ 16$ \\
\hline Lake Charles, LA & $\begin{array}{l}132-150 \\
(4.7-6.2)\end{array}$ & $\$ 11$ & $\begin{array}{l}136-154 \\
(5.0-6.6)\end{array}$ & $\$ 12$ \\
\hline Houston, TX & $\begin{array}{l}207-225 \\
(5.9-7.2)\end{array}$ & $\$ 17$ & $\begin{array}{l}211-229 \\
(6.1-7.6)\end{array}$ & $\$ 18$ \\
\hline Ft. Worth, TX & $\begin{array}{c}340-356 \\
(9.4-11.4)\end{array}$ & $\$ 28$ & $\begin{array}{c}364-369 \\
(9.9-12.0)\end{array}$ & $\$ 30$ \\
\hline Jackson, MS & $\begin{array}{l}167-185 \\
(6.8-9.0)\end{array}$ & $\$ 14$ & $\begin{array}{l}172-188 \\
(7.3-9.7)\end{array}$ & $\$ 15$ \\
\hline Orlando, FL & $\begin{array}{l}113-137 \\
(3.2-4.4)\end{array}$ & $\$ 10$ & $\begin{array}{l}108-139 \\
(3.1-4.6)\end{array}$ & $\$ 11$ \\
\hline Fresno, $\mathrm{CA}$ & $\begin{array}{c}187-211 \\
(7.5-10.9)\end{array}$ & $\$ 16$ & $\begin{array}{c}193-215 \\
(8.0-11.8)\end{array}$ & $\$ 17$ \\
\hline El Paso, TX & $\begin{array}{c}205-227 \\
(7.2-10.2)\end{array}$ & $\$ 17$ & $\begin{array}{c}212-233 \\
(7.7-11.0)\end{array}$ & $\$ 19$ \\
\hline Miami, FL & $\begin{array}{c}36-71 \\
(0.7-1.6)\end{array}$ & $\$ 4$ & $\begin{array}{c}33-77 \\
(0.7-1.7)\end{array}$ & $\$ 6$ \\
\hline Phoenix, AZ & $\begin{array}{c}677-704 \\
(11.0-13.0)\end{array}$ & $\$ 66$ & $\begin{array}{c}674-717 \\
(11.6-13.7)\end{array}$ & $\$ 57$ \\
\hline
\end{tabular}

1) Cost savings are based on electrical energy costs of $8 \mathrm{c} / \mathrm{kWh}$

2) Model floor area: $1,540 \mathrm{ft}^{2}$, air-conditioner efficiency: 8.0 , window area: $185 \mathrm{ft}^{2}$

\section{Estimates of Potential Savings}

Table A.31 provides estimates for cooling energy savings associated with insulating previously non-insulated walls with R-13, based on the study by McLain (1992). The term SIRcool represents the SIR strictly due to cooling energy savings, while the term SIRheat, required is the minimum SIR required from heating savings to make the overall SIR for this measure equivalent to 1.0. 
Table A.31. Average cooling energy and cost savings, and SIR's for installation of wall insulation in non-insulated walls, for homes with R-19 or R-30 attic insulation

\begin{tabular}{|c|c|c|c|}
\hline \multirow[b]{2}{*}{ Climate Region } & \multicolumn{3}{|c|}{ Wall Insulation Savings: SIR cool, SIR heat, required } \\
\hline & $\begin{array}{c}\text { Cooling Savings, } \\
\text { kWh } \\
\$ / y \mathbf{r}\end{array}$ & $\begin{array}{l}\text { Exterior Masonry } \\
\text { Insulation }\end{array}$ & $\begin{array}{l}\text { Blown-In Wood } \\
\text { Frame Insulation }\end{array}$ \\
\hline Humid & $\begin{array}{l}150 \mathrm{kWh} \\
\$ 12\end{array}$ & $\begin{array}{l}0.04 \\
0.96\end{array}$ & $\begin{array}{l}0.16 \\
0.84\end{array}$ \\
\hline Gulf & $\begin{array}{l}136 \mathrm{kWh} \\
\$ 11\end{array}$ & $\begin{array}{l}0.04 \\
0.96\end{array}$ & $\begin{array}{l}0.15 \\
0.85\end{array}$ \\
\hline Dry & $\begin{array}{l}156 \mathrm{kWh} \\
\$ 12\end{array}$ & $\begin{array}{l}0.04 \\
0.96\end{array}$ & $\begin{array}{l}0.16 \\
0.84\end{array}$ \\
\hline Central & $\begin{array}{c}357 \mathrm{kWh} \\
\$ 29\end{array}$ & $\begin{array}{l}0.09 \\
0.91\end{array}$ & $\begin{array}{l}0.40 \\
0.60\end{array}$ \\
\hline Pacific & $\begin{array}{c}35 \mathrm{kWh} \\
\$ 3\end{array}$ & $\begin{array}{l}\text { Low, } \\
1.0\end{array}$ & $\begin{array}{l}0.04 \\
0.96\end{array}$ \\
\hline
\end{tabular}

1) Cost savings are based on electrical energy costs of $8 \mathrm{c} / \mathrm{kWh}$

2) Extrapolated from prototype model in selected cities, in McLain (1992) study

3) Insulation lifetime: 25 years, Insulated wall area: $1,475 \mathrm{ft}^{2}$, Exterior insulation cost: $\$ 4,930$

(at $\left.\$ 3.34 / \mathrm{ft}^{2}\right)$, Blown-in cellulose cost: $\$ 1,180\left(\$ .80 / \mathrm{ft}^{2}\right)$

4) Results reflect average savings from Table A.34, for insulated attics

\section{References}

Barkaszi, S., Parker, D.S., Florida Exterior Wall Insulation Report, Florida Solar Energy Center, Cocoa, FL, December, 1995.

Cummings, James B., John J. Tooley Jr., and Neil A. Moyer, Florida Fix Weatherization Training Manual, Florida Solar Energy Center, FSEC-GP-42-89, October 1989. (S)

DOE, "Insulation Fact Sheet," DOE/CE-0180, January 1988.

Fairey, Philip W., "Florida Retrofit Options," Energy Resource and Conservation Related to Built Environment, Ural Oktay, ed., Pargamon Press, Vol 2, 1980, pp. 1033-1050. (D)

Greely, Kathy, John Randolph, and Bill Hill, "A Warm Wind Blows South: Virginia's Weatherization Evaluation," Home Energy, Jan/Feb 1992, p.15. (D)

Krigger, J., 1994. Residential Energy: Cost Savings and Comfort for Existing Buildings, Saturn Resource Management, Helena, MT.

Lstiburek, Joseph and John Carmody, Moisture Control Handbook: New, Low-rise Residential Construction, ORNL/Sub/89-SD350/1, October 1991.

McLain, H. A., "Modeling Study of the Cooling Season Performance of Exterior Wall Insulation," Proceedings 
of the Thermal Performance of the Exterior Envelopes of Buildings V, ASHRAE/DOE/BTECC, p. 655, December, 1992.

ORNL, Insulation Fact Sheet - Draft Document, Oak Ridge National Laboratory, Oak Ridge, TN, March 1996.

Randolph, J., Greely, K.M., Hill, W.W., Evaluation of the Virginia Weatherization Program: Final Report, Virginia Center for Coal and Energy Research, Blacksburg, VA, March 1991.

Ternes, M.P., Wiles, K.E., McLain, H.A., "Cooling Benefits from Exterior Masonry Wall Insulation," Home Energy, Mar/Apr 1994, p.33.

Ternes, M.P. and K.E. Wilkes, "Air-Conditioning Electricity Savings and Demand Reductions from Exterior Masonry Wall Insulation Applied to Arizona Residences," 1993 ASHRAE Transactions, Vol. 99 Part 2.

Nisson, J.D., "After the Hurricane: Energy-Retrofitting South Florida," Energy.Design Update, April, 1993. 


\section{WHOLE-HOUSE FANS}

\section{Technology Description}

Whole house fans exhaust large quantities of air from the house interior to the attic space. This provides forced ventilation even when wind speeds are low. Typically fans are operated during the cooler evening hours to take advantage of ventilation rather than air conditioning. Such a strategy provides a longer "ventilation season" in the southeast since nighttime wind speeds are typically lowest during the summer months. In addition, particularly for homes without air conditioning, whole house fans can provide cooling during the afternoon when the house is reaching its highest temperature due to trapped heat and internal heat generation. House fans also create air movement which enhances comfort (Cummings 1989).

One consideration which can serve to greatly reduce the effectiveness of whole house fans in the southeast is the higher humidity level of summertime ambient air. Traditionally, in drier climates, these fans are used when the air temperature is between 82 and $75^{\circ} \mathrm{F}$, and with relative humidity below $65 \%$. Because the comfort level associated with the higher humidity may be significantly depressed, occupants will switch to conventional cooling and the resulting energy savings will be reduced or become negligible.

Savings which can be attributed to use of a whole house fan rely heavily on the strategy assumed to control its operation. Unless control is automated, any savings will depend on the occupant choosing to use the fan instead of traditional vapor compression air conditioning. Program specification should be careful to specify a switching arrangement where either the air conditioning system or the whole house fan can be operated individually, but not simultaneously. This will avoid potential misuse.

\section{Performance / Field Studies}

\section{Florida Studies}

A field study of a home in Gainesville, Florida during the summer of 1982 found a $22 \%$ air conditioning savings using a strategy which assumed the a whole house fan ran if the outdoor temperature fell within a specified range. (Ingley et al. 1983). A second Florida study found that whole house fans dropped the average nighttime interior temperature by $2-6^{\circ} \mathrm{F}$ when operated during summer conditions (Parker 1994).

An assessment of whole house fan potential in South Florida (Parker et al. 1992) made simple assumptions regarding the potential savings of whole house fans. It was assumed that whole house ventilation could obviate the need for air conditioning in the months of February - April and October and November in Miami. Fan electrical demand averaged 300 Watts with 12 hours of operation per day resulting in a fan consumption of 3.6 $\mathrm{kWh}$ per day. The differential between the predicted air conditioning energy use for these months and the average $110 \mathrm{kWh}$ for whole house operation comprised realized savings. Savings were greatest for the months of October and April, but were still less than $200 \mathrm{kWh}$ per month, totally $530 \mathrm{kWh}$ annually (Parker et al. 1992). The study assumed that humidity was not a limitation, although it does create a bias against general application of this measure. ${ }^{8}$

\footnotetext{
8 The general idea is that the buildings windows would be automatically opened and the space ventilated by a whole-house fan when temperature and relative humidity limits were not exceeded. Although potentially very attractive in semi-arid regions, the humid conditions in the southeastern U.S. can serve to greatly limit potential. For instance, with constraints on temperature for ventilation between 23.3 and $25.6^{\circ} \mathrm{C}$ there are 1,168 hours between June and October in Miami, FL which meet this requirement. However, limiting relative humidity to less than $65 \%$ dropped this to only 159 potential hours. Finally, the times when such ventilation was possible tend to coincide with periods when the building does not require air conditioning. In Miami, only 59 of the 188 hours
} 


\section{Kusuda and Bean}

An detailed computer analysis of potential savings from whole-house fans was conducted by Kusuda and Bean (1981). They assumed a strategy in which the fan was cycled by the room thermostat. The fan was rated $450 \mathrm{~W}$. The table below shows the computed net electrical energy savings and percentage cooling savings for use of whole house fans in several southern climates.

Table A.32. Simulated estimates of net electrical energy savings and cooling energy savings for whole-house fans.

\begin{tabular}{||l|c|c|}
\hline \multicolumn{1}{|c|}{ Location } & $\begin{array}{c}\text { Net electrical energy } \\
\text { savings }(\mathrm{kWh})\end{array}$ & $\begin{array}{c}\text { Savings as percent of total } \\
\text { cooling energy (\%) }\end{array}$ \\
\hline Atlanta, GA & 912 & 29 \\
\hline Burbank, CA & 378 & 20 \\
\hline Fresno, CA & 421 & 15 \\
\hline Ft. Worth, TX & 778 & 20 \\
\hline Houston, TX & 1068 & 24 \\
\hline Phoenix, AR & 420 & 9 \\
\hline \hline Average & 662 & 20 \\
\hline
\end{tabular}

\section{Texas Study}

Burch and Treado (1979) measured the savings of a whole-house fan on air conditioning in a house in Houston, Texas. The fan was operated when the temperature outside was less than $82^{\circ} \mathrm{F}$ and greater than $75^{\circ} \mathrm{F}$. They found that the savings was well correlated with the daily average outdoor temperature. Savings varied from $65 \%$ at $76^{\circ} \mathrm{F}$ to $10 \%$ at $84{ }^{\circ} \mathrm{F}$.

\section{Other Considerations}

Whole house fans create negative pressure within the house and this has two potentially important implications. First, the fans should not be installed in homes with gas water heaters located in the living space. Operation of the fan can cause backdrafting of the appliance, drawing combustion products into the living space. It can also cause "flame roll-out" from the water heater. Secondly, studies have shown that radon levels in a house operating a whole house fan can be increased despite the windows being opened (Cummings 1989).

\section{Estimates of Savings Potential}

The sources reviewed indicate potential savings of about $20 \%$ of the cooling energy use from use of a whole house. However, none of the studies sufficiently account for the detrimental affects of humidity on the savings. The table below summarizes the economics of the measure based on the assumption of a $10 \%$ savings in the Gulf and Humid climates (accounting for the humidity restrictions), $15 \%$ for the Pacific climate region, and $20 \%$ for the Arid/Central regions. Cooling energy consumptions for the climate regions are taken from 1990 EIA

predicted air conditioning would be required, and even those periods tended to have a low level of $\mathrm{AC}$ power demand. Obviously, a similar analysis could be completed for various locations around the southeastern U.S. 
residential consumption data (1993). The cost of fan installation ranges from $\$ 125$ to $\$ 470$. The cost will vary, particularly depending on the labor charge for installation. The estimates below assume an installed cost of $\$ 200$. Also assumed are an electric rate of $\$ .08 / \mathrm{kWh}$ and useful life of 10 years.

Table A.33. Energy and cost savings, and SIR's for whole house fans

\begin{tabular}{|c|c|c|}
\hline $\begin{array}{c}\text { Climate } \\
\text { Region }\end{array}$ & $\begin{array}{c}\text { Cooling } \\
\text { Savings, } \\
\text { kWh, \$/yr }\end{array}$ & SIR \\
\hline Humid & $135 \mathrm{kWh}, \$ 11$ & 0.45 \\
\hline Gulf & $278 \mathrm{kWh}, \$ 22$ & 0.90 \\
\hline Dry/Central & $328 \mathrm{kWh}, \$ 26$ & 1.06 \\
\hline Pacific & $50 \mathrm{kWh}, \$ 4$ & 0.17 \\
\hline
\end{tabular}

\section{References}

Burch, D.M. and Treado, S.J., "Ventilating Residences and their Attics for Energy Conservation," in Summer Attic and Whole House Ventilation, NBS Special Publication 548, National Bureau of Standards, Washington D.C., 1979.

Cummings, James B., John J. Tooley Jr., and Neil A. Moyer, Florida Fix Weatherization Training Manual, Florida Solar Energy Center, FSEC-GP-42-89, October 1989.

EIA, 1993, Household Energy Consumption and Expenditures 1990, Energy Information Administration, DOE/ELA-0321 (90), February 1993.

Ingley, H.A., Dixon, R.W. and Buffington, D.E., Residential Conservation Demonstration Program, Florida Public Service Commission, University of Florida, Gainesville, FL, 1983.

Kusuda, T. and Bean, J.W. Savings in Electric Cooling Energy by the Use of a Whole House Fan, NBS Technical Note 1138, National Bureau of Standards, Washington D.C., May, 1981.

Parker, D., Fairey, P., Gueymard, C., McCluney, R., Mcllvaine, J. and Stedman, T., 1992. Rebuilding for Efficiency: Improving the Energy Use of Reconstructed Residences in South Florida, FSEC-CR-562-92, Florida Solar Energy Center, Cape Canaveral, FL. 


\section{WINDOW REPLACEMENT}

\section{Technology Description}

In cooling climates, windows can contribute as much as $20 \%$ of the total space conditioning load of a house (Cummings 1989). In the cooling season, solar radiation entering the house through windows can contribute up to $30 \%$ of the homes cooling load (Warner 1990). In addition, poorly fitting windows are a major source of infiltration. Clearly, proper attention to windows in weatherizing a home can provide significant benefits.

Because of the many mechanisms of heat transfer associated with windows, determining an accurate estimate for the cost-effectiveness of window replacements and addition of storm windows can be a complex procedure. Decisions regarding window replacements become even more difficult when multiple approaches to solving the same energy anomaly exist. For example, infiltration around a window could, in many cases, be reduced by either (1) using caulk and weatherstripping, (2) adding a tight-fitting storm window, or (3) totally replacing the window. If this infiltration were the only heat transfer mechanism of concern and no extenuating circumstances existed, the most cost effective solution would be the least expensive one, probably one of the first two. However, other factors will likely also need to be considered.

The following will address only window replacement as an energy conservation option. Even if replacement is found to be cost-effective, other less expensive alternatives should also be examined in order to determine the most cost-effective option. "Windows that have sash leaks or excessive air infiltration, installation deficiencies, or which have deteriorated to the point that caulking and weatherstripping cannot be made effective, are likely candidates for replacement." (NCEL 1990).

Window manufacturers now design windows for specific applications of climate and orientation (Nisson 1994). Low-E double-pane windows generally give an added $R$ ( 3 instead of 2 ) of insulating ability over their non-treated equivalents. In addition, the coatings can now either allow or block solar heat gain, depending on their application, yet with good transmission of visible light. Windows with high shading coefficients (SC) allow solar heat gain to enter a house to reduce the heating load, while those with low SC are designed primarily for cooling climates. The latter would be most applicable for east and west facing windows in cooling climates. Tinted windows also have the ability to block solar heat gain and their cost may be less; however, they restrict vision more than the newer low-E windows. Recommendations of specific brand names and models are available in the literature.

Several manufacturers have recently marketed what is referred to as a "warm edge" window. The window frames use a less conductive spacer between the panes of multi-paned windows. The major advantage is reduction in the moisture condensation at the edge of the windows. Though likely most effective for reducing the condensation on the inside of the window in winter, they may also reduce exterior condensation in air-conditioned homes during humid cooling seasons. (Nisson 1994)

\section{Performance / Field Studies}

Data on performance of window systems have been obtained primarily through "hot box" tests (e.g., Arasteh 1986, Dubrous 1989) and tests performed by Lawrence Berkeley Laboratory using the mobile window test facility, MoWiTT (Mobile Windows Thermal Test Facility) (e.g., Klems 1986A, 1986B). Hot box tests measure the heat which passes through a window sandwiched between two boxes of known and constant temperature. The MoWiTT facility took similar measurements except where one side of the window was exposed to actual outdoor conditions and the experiment could be moved to any geographical location. 
The results of these tests confirmed calculational models of window performance, the most widely known being the "Window" program developed the Windows and Daylighting Group of Lawrence Berkeley Laboratory (LBL 1992). Few in-situ tests of window replacement performance could be found. Subbarao (1994) performed tests where windows in 20 homes in the northwest were replaced with "Superwindows" (triple-paned, low-E, krypton filled windows). These tests did find significant savings from the retrofit, though somewhat less than calculation procedures had predicted. However, such windows are not appropriate for low-income use due to their cost.

A relatively extensive guide to window replacement and a method of computing estimates of window performance is provided in a study performed by the Brookhaven National Laboratory and published by the Naval Civil Engineering Laboratory (NCEL 1990). The model accounts for all of the major heat transfer mechanisms present in window performance: conduction, infiltration, and solar radiation. Data assembled for this report relevant to window replacements in cooling climates include the following:

- "For areas where heating and air-conditioning are frequently used, it is recommended that windows... be double-glazed rather than single-glazed in order to conserve energy."

- "For areas where cooling is of greater importance than heating, consider low-emissivity hard coat glass with low shading coefficients for greater protection against the sun."

- During the summer, low-emissivity glass helps to block reradiated heat generated by outdoor objects, hot driveways, pavements. etc. " "For hot climates, surface 2 [inner surface of external pane] is the preferred surface for the low-e coating.

- Aluminum frames are "economical to build and install," "require little or no maintenance," and "won't warp, rot, or swell." However, "poor thermal performance renders [them] highly energy-inefficient." "In addition, bare aluminum frames are subject to pitting and corrosion in coastal areas where they are constantly exposed to moist salt air, thus affecting their long-term durability.

- Despite wood frames having "the lowest rate of conduction heat loss of all framing materials," it is a "highmaintenance material," it "tends to absorb moisture and swell, and is particularly a problem under high humidity conditions." "The repeated expansion and contraction of wood due to moisture absorption, if it goes untreated, can become more of a problem as it may cause warping. This is an important factor in hot humid climates."

- Vinyl Frames have the advantages of "low-maintenance with excellent thermal properties." They have "extreme durability for outdoor weather" are "strong, abrasion-resistant, and chemically inert," "will not chip, flake, rust, blister, or peel, "swell, shrink, warp." They are "virtually maintenance-free." "Because of the lack of clear evidence that brown-colored PVC can maintain long life, or that it can be successfully used for windows in areas with hot climates," "white and beige vinyl windows should be the colors of choice." "Vinyl has several significant attributes, among them being that it is less costly than wood or thermalized aluminum windows."

\section{Estimates of Savings Potential}

The following data were computed from the algorithms contained in the NCEL report. The manual procedure accommodates most fenestration options and could be used to cost-justify specific retrofits. However, in order to include cooling savings, the forms needing completion fill five pages and require numerous entries from tables and charts. Tables A.34 and A.35 summarize the results of application of the procedure for electric resistance 
and natural gas heat, respectively. Assumptions used in developing the tables include: fuel prices of $\$ 5.95 / \mathrm{MBtu}$ and $\$ 0.0824 / \mathrm{kWh}$ for gas and electric, respectively; furnace efficiency of $70 \%$ and air conditioner SEER of 8.0 ; and a discount rate of $4.1 \%$. The computations were performed assuming both existing and retrofit windows were double, though other types would likely have similar results.

The retrofit window was assumed to be a two pane, wood or vinyl frame window, either standard or low-e. Installed costs for these two types of windows were assumed to be $\$ 144$ and $\$ 172$ per unit. Costs for windows may vary widely. Adjustments to account for cost differences may be made by multiplying the reported SIR by the ratio of this assumed cost and the actual cost.

It must be reiterated, however, simply showing a window replacement option cost-effective does not necessarily justify its implementation. If a significant portion of the retrofit savings stems from infiltration reduction afforded by the new window, less costly infiltration reduction procedures (caulking, weatherstripping, etc.) may be substantially more cost-effective than the window replacement. 
Table A.34. Savings-to-investment ratios for window replacement options. Natural gas heat

\begin{tabular}{|c|c|c|c|c|c|c|c|c|}
\hline \multirow{3}{*}{$\begin{array}{l}\text { Retrofit window } \\
\text { Existing window }\end{array}$} & \multicolumn{4}{|c|}{ Standard 2-pane window } & \multicolumn{4}{|c|}{ Low-E 2-pane window } \\
\hline & \multicolumn{2}{|c|}{ Tight-fitting } & \multicolumn{2}{|c|}{ Average-fitting } & \multicolumn{2}{|c|}{ Tight-fitting } & \multicolumn{2}{|c|}{ Average-fitting } \\
\hline & $\begin{array}{l}\text { Metal } \\
\text { frame }\end{array}$ & $\begin{array}{l}\text { Wood } \\
\text { frame }\end{array}$ & $\begin{array}{l}\text { Metal } \\
\text { frame }\end{array}$ & $\begin{array}{l}\text { Wood } \\
\text { frame }\end{array}$ & $\begin{array}{l}\text { Metal } \\
\text { frame }\end{array}$ & $\begin{array}{l}\text { Wood } \\
\text { frame }\end{array}$ & $\begin{array}{l}\text { Metal } \\
\text { frame }\end{array}$ & $\begin{array}{l}\text { Wood } \\
\text { frame }\end{array}$ \\
\hline Birmingham, AL & 0.43 & 0.29 & 1.44 & 1.00 & 0.49 & 0.37 & 1.09 & 0.97 \\
\hline Charleston, SC & 0.38 & 0.26 & 0.99 & 0.88 & 0.44 & 0.34 & 0.95 & 0.85 \\
\hline Dallas, TX & 0.45 & 0.31 & 1.19 & 1.06 & 0.53 & 0.41 & 1.15 & 1.03 \\
\hline Little Rock AK & 0.50 & 0.33 & 1.36 & 1.19 & 0.56 & 0.41 & 1.28 & 1.13 \\
\hline Los Angeles, CA & 0.26 & 0.17 & 0.71 & 0.61 & 0.29 & 0.21 & 0.67 & 0.59 \\
\hline Miami, FL & 0.24 & 0.20 & 0.49 & 0.45 & 0.29 & 0.26 & 0.50 & 0.47 \\
\hline New Orleans, LA & 0.31 & 0.23 & 0.78 & 0.69 & 0.37 & 0.30 & 0.76 & 0.69 \\
\hline Phoenix, AZ & 0.56 & 0.43 & 1.39 & 1.26 & 0.68 & 0.57 & 1.38 & 1.27 \\
\hline San Antonio, TX & 0.42 & 0.31 & 1.04 & 0.93 & 0.51 & 0.41 & 1.02 & 0.94 \\
\hline Tampa, FL & 0.27 & 0.22 & 0.62 & 0.56 & 0.34 & 0.29 & 0.63 & 0.58 \\
\hline
\end{tabular}

Table A.35. Savings-to-investment ratios for window replacement options. Electric resistance heat

\begin{tabular}{|c|c|c|c|c|c|c|c|c|}
\hline Retrofit window & \multicolumn{4}{|c|}{ Standard 2-pane window } & \multicolumn{4}{|c|}{ Low-E 2-pane window } \\
\hline \multirow{2}{*}{ Existing window } & \multicolumn{2}{|c|}{ Tight-fitting } & \multicolumn{2}{|c|}{ Average-fitting } & \multicolumn{2}{|c|}{ Tight-fitting } & \multicolumn{2}{|c|}{ Average-fitting } \\
\hline & $\begin{array}{l}\text { Metal } \\
\text { frame }\end{array}$ & $\begin{array}{l}\text { Wood } \\
\text { frame }\end{array}$ & $\begin{array}{l}\text { Metal } \\
\text { frame }\end{array}$ & $\begin{array}{l}\text { Wood } \\
\text { frame }\end{array}$ & $\begin{array}{l}\text { Metal } \\
\text { frame }\end{array}$ & $\begin{array}{l}\text { Wood } \\
\text { frame }\end{array}$ & $\begin{array}{l}\text { Metal } \\
\text { frame }\end{array}$ & $\begin{array}{l}\text { Wood } \\
\text { frame }\end{array}$ \\
\hline Birmingham, $\mathrm{AL}$ & 1.11 & 0.65 & 3.26 & 2.80 & 1.15 & 0.76 & 2.95 & 2.56 \\
\hline Charleston, SC & 0.93 & 0.56 & 2.69 & 2.31 & 0.97 & 0.66 & 2.44 & 2.13 \\
\hline Dallas, TX & 1.04 & 0.60 & 3.12 & 2.68 & 1.10 & 0.73 & 2.84 & 2.47 \\
\hline Little Rock AK & 1.35 & 0.76 & 3.33 & 3.44 & 1.38 & 0.89 & 3.62 & 3.13 \\
\hline Los Angeles, $\mathrm{CA}$ & 0.77 & 0.42 & 2.35 & 1.99 & 0.78 & 0.49 & 2.10 & 1.81 \\
\hline Miami, FL & 0.33 & 0.26 & 0.69 & 0.64 & 0.34 & 0.30 & 0.66 & 0.60 \\
\hline New Orleans, LA & 0.68 & 0.42 & 1.92 & 1.67 & 0.73 & 0.51 & 1.77 & 1.55 \\
\hline Phoenix, AZ & 0.99 & 0.63 & 2.82 & 2.46 & 1.10 & 0.80 & 2.63 & 2.33 \\
\hline San Antonio, TX & 0.82 & 0.51 & 2.31 & 2.01 & 0.90 & 0.63 & 2.15 & 1.89 \\
\hline Tampa, FL & 0.47 & 0.33 & 1.21 & 1.06 & 0.52 & 0.41 & 1.14 & 1.02 \\
\hline
\end{tabular}




\section{References}

Arasteh, D., J. Hartmann, and M. Rubin, Experimental Verification of a Model of Heat Transfer Through Windows, Lawrence Berkeley Laboratory, LBL-21576, December 1986.

Cummings, James B., John J. Tooley Jr., and Neil A. Moyer, Florida Fix Weatherization Training Manual, Florida Solar Energy Center, FSEC-GP-42-89, October 1989.

Dubrous, F. M. and S. J. Harrison, "Comparison of Experimental Test Results and Analytical Calculations of Window Thermal Performance," ASHRAE Transactions, Volume 95, Part 2, 1989.

Klems, J. and H. Keller, Measurement of Single and Double Glazing Thermal Performance Under Realistic Conditions Using the Mobile Window Thermal Test (MoWiTT) Facility, LBL-22149, November 1986.

Klems, J. and H. Keller, Thermal Performance Measurements of Sealed Insulating Glass Units with Low-E Coatings Using the MoWiTT Field-Test Facility, LBL-21583, December 1986.

Lawrence Berkeley Laboratory (LBL), Window 4.0 for Analyzing Window Thermal Performance, Windows and Daylighting Group, Energy and Environment Division, LBL-32091 UC-350, March 1992.

Naval Civil Engineering Laboratory (NCEL), Energy-Efficient Windows and Window Coverings for Naval Housing, "An Investigation Conducted by Brookhaven National Laboratory," CR 90.01 1, July 1990.

Nisson, J.D., Ed., "Anderson and Kolbe Adopt 'Warm Edge' Window Technology," Energy Design Update, February, 1994.

Nisson, J.D., Ed., "Low-E Windows for Warm and Cold Climates," Energy Design Update, February, 1994.

Subbarao, K., "Energy Performance of Superwindow Retrofits, Macrodyne Energy International, Inc., prepared for the Bonneville Power Administration, April 1994.

Warner, Jeffrey L., "Consumer Guide to Energy-Saving Windows," Home Energy, Jul/Aug 1990, pgs 17-22. 


\section{WINDOW SCREENS AND NATURAL VENTILATION}

\section{Technology Description}

Window screens may be installed to reduce the level of contaminants, such as bugs and leaves, that may be introduced into a home during ventilation. The installation of these screens will promote the use of natural and/or forced ventilation, due to the increase in relative air quality. Unfortunately, insect screens may reduce wind speeds entering the home by up to 50\% (Lechner 1991). Natural ventilation alone, even with a strong cross-wind, is generally unable to provide adequate cooling for the occupants. Sole reliance on natural ventilation in hot climates can have dangerous consequences for the elderly and infants while reducing the mental acuity of others (Parker et. al. 1996). Convective cooling is usually only effective on humans when airflows are above 100-300 fpm (Fairey 1985). During the summer, nighttime windspeeds tend to be low and provide fresh air to the house at speeds of only 20-30 fpm. Additional relief is usually required from either window fans or a whole-house fan. This form of 'comfort ventilation' works best when temperatures range from $68^{\circ} \mathrm{F}$ to $88^{\circ} \mathrm{F}$, with corresponding relative humidities of $20 \%$ to $80 \%$.

\section{Performance/Field Studies}

Window screens are a widely used weatherization measure, especially in homes located in the warm climate region. The approximate cost for repairing or replacing window screens is $\$ 12-\$ 20$, per screen (Cummings 1989, Means 1996). The major benefits include increased occupant comfort and contaminant reduction, while little energy savings may be directly attributed solely to this measure. However in low-income homes, energy savings may occur when tenants use natural or forced ventilation instead of air-conditioning. According to field studies performed in North Carolina and Oklahoma, low-income residents often tolerated higher temperatures and depended on fans, in order to save on utility bills (Sharp 1994, Ternes 1992). In North Carolina, this kept annual cooling costs below $\$ 21$ in $40 \%$ of the homes studied. The Oklahoma study reported that high indoor temperatures and low air-conditioning consumption indicated that tenants where choosing to ventilate over running their air-conditioner.

\section{Other Considerations}

- The installation and/or repair of window screens, performed in conjunction with installation of window and/or whole-house ventilation fans, is recommended in order to ensure the proper use of the new ventilation system.

- Insect screens will contribute some shading to windows, thus reducing cooling energy use even when the windows are not opened to provide ventilation.

\section{Estimates of Potential Savings}

Estimates on cooling energy savings due to screens and natural ventilation, alone, are negligible. Further research would help to quantify improvements in comfort provided by use of natural ventilation.

\section{References}

Cummings, James B., John J. Tooley Jr., and Neil A. Moyer, Florida Fix Weatherization Training Marual, Florida Solar Energy Center, FSEC-GP-42-89, October 1989.

Fairey, P.W., Kerestecioglu, A.A., Chandra, S., 1985. "Ventilative Cooling in Southern Residences: A 
Parametric Analysis," Proceedings of the Thermal Performance of the Exterior Envelopes of Buildings III, ASHRAE/DOE/BTECC, p. 484, December, 1985.

Lechner, N., 1991. Heating, Cooling, Lighting: Design Methods for Architects, John Wiley \& Sons, NY, NY.

Means, 1996. Means Repair \& Remodeling Cost Data, 17th Edition, R.S. Means Co., Kingston, MA.

Parker, Danny S., Stephen F. Barkaszi Jr., John R. Sherwin, and C. Steven Richardson, "Central Air Conditioner Usage Patterns in Low-Income Housing in a Hot and Humid Climate: Influences on Energy Use and Peak Demand," Proceedings of the ACEEE 1996 Summer Study on Energy Efficiency in Buildings, Vol. 8, p. 147.

Sharp, T., 1992. The North Carolina Field Test: Field Performance of the Preliminary Version of an Advanced Weatherization Audit for the Department of Energv's Weatherization Assistance Program, ORNL/CON-362, Oak Ridge National Laboratory, Oak Ridge, TN, June, 1994.

Ternes, M. P. and Levins, W. P. Oklahoma Field Test: Air Conditioning Electricity Savings from Standard Energy Conservation Measures, Radiant Barriers and High-Efficiency Window Air Conditioners, ORNL/CON317, Oak Ridge National Laboratory, Oak Ridge, TN, August, 1992. 


\section{INTERNAL DISTRIBUTION}
1. J. E. Christian
2. G. E. Courville
3. T. R. Curlee
4. A. O. Desjarlais
5-25 M. B. Gettings
26. S. G. Hildebrand
$27-47$
48.

49.

50.

51.

52.

53. Central Research Library

54. Document Reference Section

55. Laboratory Records-RC

\section{EXTERNAL DISTRIBUTION}

56. Lilia A. Abron, President, PEER Consultants, P.C., 1000 N. Ashley Drive, Suite 312, Tampa, Florida 33602

57. Larry Ahasteen, Project Manager, Navajo Housing Services Department, PO Box 2396, Willow Rock, Arizona 86515

58. J. A. Almaguer, Project Manager, Texas Department of Housing and Community Affairs, 811 Barton Springs Road, PO Box 13941, Austin, Texas 78711-3941

59. Lynn Ballard, Project Manager, Office of Energy Services, Department of Community \& Economic Development, 324 South State Street, Suite 230, Salt Lake City, Utah 84111

60. William Beachy, Project Manager, Division of Housing, Department of Housing \& Community Development, 501 North Second Street, Richmond, Virginia 23219-1321

61. Earl Billings, Florida Department Of Community Affairs, Housing and Community Development, 2555 Shumard Oak Blvd., Tallahassee, Florida 32399-2100

62. Troy Branscum, Project Manager, Office of Community Services, Division of Economic \& Medical Services, Department of Human Services, PO Box 1437, Slot \#1330, Little Rock, Arkansas 72203-1437

63. Jeff Brown, Aspen Systems, 8498 Webbs Mill Road, Spring Hope, North Carolina 272611

64. Elizabeth Cahall, Philadelphia Support Office, 1880 JFK Boulevard, Suite 501, Philadelphia, Pennsylvania 19103

65. Percy Carter, Project Manager, Energy Division, Department of Commerce, 430 North Salisbury Street, Raleigh, North Carolina 27611

66. Russell Clark, Project Manager, Department of Commerce, Energy Office, 3800 North Central Ave., Suite 1200, Phoenix, Arizona 85012 
67. Liz Cordova, Project Manager, Energy Conservation \& Management Division, New Mexico Energy, Mineral \& Natural Resources Department, 2040 South Pacheco, Santa Fe, New Mexico 87505

68-69. Dennis Creech, Southface Energy Institute, Inc., 241 Pine Street, Atlanta, Georgia 30308

70. Bernadette Cross, Atlanta Support Office, 730 Peachtree Street, NE, Suite 876, Atlanta, Georgia 30308

71. Marian Downs, Denver Support Office, 1617 Cole Boulevard, Golden, Colorado 80401

72. Vicki DeKoelkoek, Project Manager, Nevada State Welfare Division, Capitol Complex, 2527 North Carson Street, Carson City, Nevada 89710

73. Jean Diggs, Department of Energy, FORS/EE-532, 1000 Independence, Ave., SW, Washington, DC 20585-0121

74. Dennis Doi, Project Manager, Office of Community Services, Department of Labor \& Industrial Relations, 335 Merchant Street, Room 101, Honolulu, Hawaii 96813

75. Thomas E. Drabek, Professor, Department of Sociology, University of Denver, Denver, Colorado 80208-0209

76-85. J. F. Eisenberg, ORNL, Capitol Gallery Bldg, Suite 306W, 600 Maryland Ave., SW, Washington, DC 20024

86. Rich Eversman, Project Manager, Department of Social Insurance, CHR Building, 3rd Floor West, Energy Assistance Branch, 275 East Main Street, Frankfort, Kentucky 40621

87. Jim Golden, Energy Efficient Building Association, 2950 Metro Drive, Suite 108, Minneapolis, Minnesota 55424

88. Joseph Guerro, Texas Department of Housing \& Community Affairs, PO Box 13941, Austin, Texas 78711-3941

89. John Harper, Chicago Support Office, One South Wacker Drive, Suite 2380, Chicago, Illinois 60606

90. Phil Hayes, Department of Energy, FORS/EE-521, 1000 Independence, Ave., S W Washington, DC 20585-0121

91. Benjamin F. Hobbs, The Johns Hopkins University, Department of Geography and Environmental Engineering, Arees Hall, Baltimore , Maryland 21218

92. Cherry Ivey, Project Manager, Office of Energy Resources, State of Georgia, 254 Washington Street, SW, Suite 401, Atlanta, Georgia 303348502

93. Brenda Jones, Project Manager, Community Services division, Department of Economic \& Community Affairs, 401 Adams Ave., PO Box 5690, Montgomery, Alabama 36102-5690

94. Douglas Keisler, Project Manager, Office of the Governor, Division of Economic Opportunity, 1205 Pendleton Street, 3rd Floor, Columbia, South Carolina 29201-3713 
95-98. Gail McKinley, Department of Energy, DVSO, 1000 Independence Ave., S W Washington, DC 20585-0121

99. Marlyn Nelson, Project Manager, Office of Community Services, Department of Social Services, PO Box 3318, Baton Rouge, Louisiana 70821

100-101. OSTI, U.S. Department of Energy, P.O. Box 62, Oak Ridge, TN 37831 (2)

102.

ORNL Site Manager, U.S. Department of Energy, Oak Ridge National

Laboratory, P.O. Box 2008, Oak Ridge, Tennessee 37831-6269

103. Bobby Pamplin, Project Manager, Department of Human Services, Division of Community Services, 730 North State Street, Jackson, Mississippi 39202

104. Richard Putnam, Seattle Support Office, 800 Fifth Avenue, Suite 3950, Seattle, Washington 98104

105. Christine Reinfelds, Boston Support Office, One Congress Street, 11th Floor, Boston, Massachusetts 02114

106. P. Richard Rittelmann, FAIA, Executive Vice President, Burt Hill Kosar Rittelmann Associates, 400 Morgan Center, Butler, Pennsylvania 160015977

107. Ronald Santoro, Department of Energy, FORS/EE-522, 1000 Independence Ave., SW Washington, DC 20585-0121

108. Carolyn Sullivan, Project Manager, Division of Community Affairs \& Development, Oklahoma Department of Commerce, PO Box 26980, Oklahoma City, Oklahoma 73126--980

109. Susan F. Tierney, The Economic Resource Group, Inc., One Mifflin Place, Cambridge, Massachuseets 02138

110. May Wait, Project Manager, Office of Economic Opportunity, 700 North 10th Street, Suite 272, Sacramento, California 95814

111. Zelma Waller, Project Manager, Tennessee Department of Human Services, Citizens Plaza Building, 400 Deaderick Street, Nashville, Tennessee 37248-9500

112. C. Michael Walton, Ernest H. Cockrell Centennial Chair in Engineering and Chairman, Department of Civil Engineering, University of Texas at Austin, Austin, Texas 78712-1076

113. Charles Young, Project Manager, Energy Division, Department of Commerce, 430 North Salisbury Street, Raleigh, North Carolina 27611 